\title{
Analysis of Two Biomass Gasification/ Fuel Cell Scenarios for Small-Scale Power Generation
}

Wade A. Amos

National Renewable Energy Laboratory

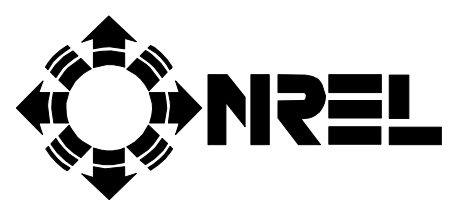

National Renewable Energy Laboratory 1617 Cole Boulevard Golden, Colorado 80401-3393

A national laboratory of the U.S. Department of Energy Operated by Midwest Research Institute for the U.S. Department of Energy

Under Contract No. DE-AC36-83CH10093 


\section{Analysis of Two Biomass Gasification/Fuel Cell Scenarios for Small-Scale Power Generation}

Wade A. Amos

National Renewable Energy Laboratory

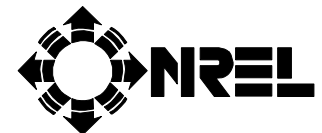

National Renewable Energy Laboratory 1617 Cole Boulevard Golden, Colorado 80401-3393

A national laboratory of the U.S. Department of Energy Operated by Midwest Research Institute for the U.S. Department of Energy

Under Contract No. DE-AC02-83CH10093

Prepared under Task No. BP911030

November 1998 


\section{NOTICE}

This report was prepared as an account of work sponsored by an agency of the United States government. Neither the United States government nor any agency thereof, nor any of their employees, makes any warranty, express or implied, or assumes any legal liability or responsibility for the accuracy, completeness, or usefulness of any information, apparatus, product, or process disclosed, or represents that its use would not infringe privately owned rights. Reference herein to any specific commercial product, process, or service by trade name, trademark, manufacturer, or otherwise does not necessarily constitute or imply its endorsement, recommendation, or favoring by the United States government or any agency thereof. The views and opinions of authors expressed herein do not necessarily state or reflect those of the United States government or any agency thereof.

Available to DOE and DOE contractors from:

Office of Scientific and Technical Information (OSTI)

P.O. Box 62

Oak Ridge, TN 37831

Prices available by calling (423) $576-8401$

Available to the public from:

National Technical Information Service (NTIS)

U.S. Department of Commerce

5285 Port Royal Road

Springfield, VA 22161

(703) 487-4650

or

DOE Information Bridge

http://www.doe.gov/bridge/home.html

Printed on paper containing at least $50 \%$ wastepaper, including $20 \%$ postconsumer waste 


\section{EXECUTIVE SUMMARY}

Two scenarios were examined for small-scale electricity production from biomass using a gasifier/fuel cell system. In one case, a stand-alone Battelle Columbus Laboratory/Future Energy Resources gasifier is used to produce synthesis gas that is reformed and distributed though a pipeline network to individual phosphoric acid fuel cells. In the second design, the gasifier is integrated with a molten carbonate fuel cell stack and a steam bottoming cycle. In both cases, the gasifiers are fed the same amount of material, with the integrated system producing $4.0 \mathrm{MW}$ of electricity, and the stand-alone design generating 2.0 MW of electricity.

The current capital cost of the stand-alone system was estimated to be $\$ 15$ million, including $\$ 4.8$ million for the phosphoric acid fuel cells. The electricity selling price, including depreciation and a $15 \%$ after-tax internal rate of return, was $\$ 0.47 / \mathrm{kWh}$. The integrated gasifier had a total capital investment of $\$ 22$ million and an electricity selling price of $\$ 0.31 / \mathrm{kWh}$. Even the lowest-cost case, with zero profit, wood residue feed prices and a future fuel cell cost of $\$ 1,000 / \mathrm{kW}$, the cost for the integrated design was still $\$ 0.11 / \mathrm{kWh}$.

These power conversion efficiencies were lower than expected because less than $100 \%$ of the fuel was utilized in the fuel cells, oxidant and fuel streams were diluted with inert gases, the fuel cells had high excess air requirements, and considerable heat was lost to the flue gas. The integrated plant design had an overall electric conversion efficiency of $43 \%$. The stand-alone design had an efficiency of $22 \%$, partly because some of the raw synthesis gas must be burned to supply heat to the gas processing operations. The stand-alone design does, however, provide a total of $10.7 \mathrm{GJ} / \mathrm{h}(10.3 \mathrm{MM} \mathrm{Btu} / \mathrm{h})$ of heat at the fuel cell sites to bring the systerstotal efficiency up to $54 \%$ on a higher heating value basis.

Future work in the area of integrated biomass gasification and fuel cell systems should concentrate on eliminating drying or improving the energy efficiency of drying operations, developing low-cost separation processes to recovery and reuse the unreacted fuel leaving the fuel cell, and determining more accurate fuel cell costs. 


\section{TABLE OF CONTENTS}

1.0 INTRODUCTION

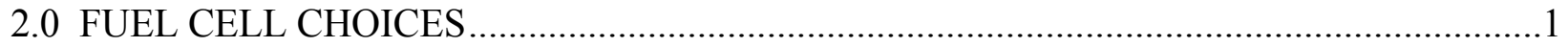

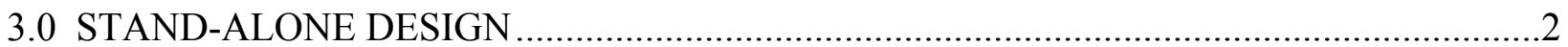

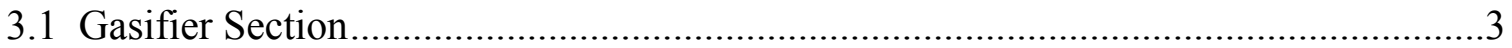

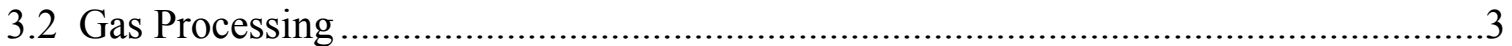

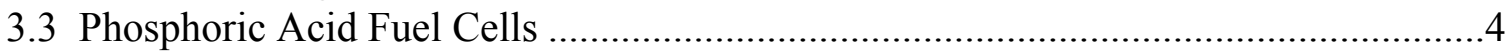

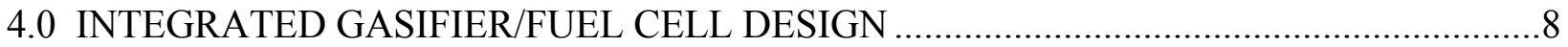

4.1 The Integrated Gasifier ……………............................................................

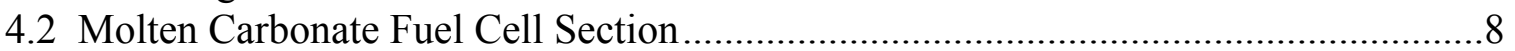

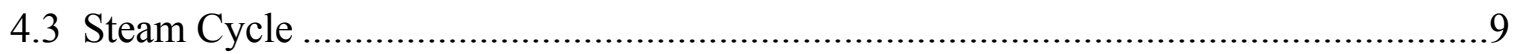

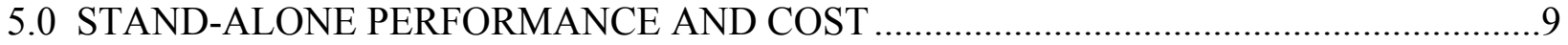

5.1 Stand-Alone Gasifier Cost ..............................................................................

5.2 Stand-Alone Gasifier Efficiency and Heat Availability.................................................

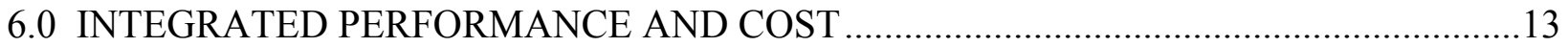

6.1 Integrated System Cost …………………………................................................13

6.2 Integrated System Efficiency …………………………........................................13

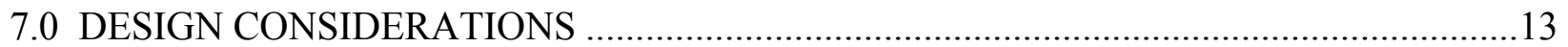

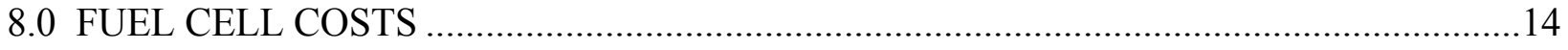

9.0 WOOD COSTS

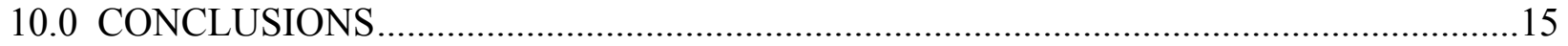

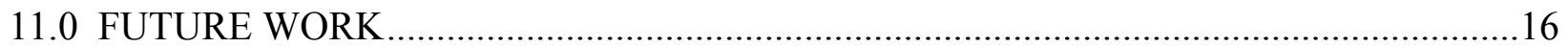

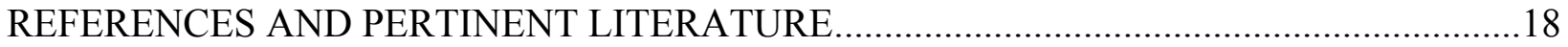

APPENDIX A - ECONOMIC CALCULATIONS

APPENDIX B - STREAM TABLES 


\begin{tabular}{|c|c|}
\hline ABBREV & IATIONS AND ACRONYMS \\
\hline acfh & Actual cubic feet per hour \\
\hline acfm & Actual cubic feet per minute \\
\hline $\mathrm{AFC}$ & Alkaline fuel cell \\
\hline BCL & Battelle Columbus Laboratory (gasifier) \\
\hline BD & Bone dry $(0 \%$ moisture $)$ \\
\hline Btu & British thermal unit \\
\hline$\sim \mathrm{C}$ & Degrees Celsius \\
\hline $\mathrm{CH}_{4}$ & Methane \\
\hline $\mathrm{CO}$ & Carbon monoxide \\
\hline $\mathrm{CO}_{2}$ & Carbon dioxide \\
\hline ESP & Electrostatic precipitator \\
\hline$\sim \mathrm{F}$ & Degrees Fahrenheit \\
\hline $\mathrm{FCI}$ & Fixed capital investment \\
\hline FERCO & Future Energy Resources Company \\
\hline $\mathrm{ft}$ & Feet \\
\hline gpm & Gallons per minute \\
\hline $\mathrm{H}_{2}$ & Hydrogen \\
\hline hp & Horsepower \\
\hline $\mathrm{h}$ & Hour \\
\hline IRR & Internal rate of return \\
\hline $\mathrm{kg}$ & Kilogram \\
\hline $\mathrm{kJ}$ & Kilojoule \\
\hline $\mathrm{kPa}$ & Kilopascal \\
\hline kW & Kilowatt \\
\hline $\mathrm{kWh}$ & Kilowatt-hour \\
\hline lb & Pound \\
\hline $\mathrm{MCFC}$ & Molten carbonate fuel cell \\
\hline MM Btu & Million British thermal units \\
\hline MM\$ & Million dollars \\
\hline MW & Megawatt \\
\hline PAFC & Phosphoric acid fuel cell \\
\hline PEM & Polyelectrolyte membrane (fuel cell) \\
\hline PEMFC & Polyelectrolyte membrane fuel cell \\
\hline ppm & Parts per million \\
\hline psig & pounds (force) per square inch gauge pressure \\
\hline SOFC & Solid oxide fuel cell \\
\hline TDC & Total direct cost \\
\hline $\mathrm{TIC}$ & Total indirect cost \\
\hline ton & English ton (2,000 pounds) \\
\hline tonne & Metric tonne (1,000 kilograms) \\
\hline tpd & Tons per day \\
\hline $\mathrm{yr}$ & Year \\
\hline
\end{tabular}




\subsection{INTRODUCTION}

The purpose of this report was to evaluate the feasibility of producing electricity on a small scale using a Battelle Columbus Laboratory/Future Energy Resources Company (BCL/FERCO) gasifier linked to a fuel cell system. Two scenarios were examined: one where stand-alonøir centralized gasifier is supplying synthesis gas to a pipeline network with a number of phosphoric acid fuel cells (PAFCs), and a second case with a higher-temperature molten carbonate fuel cell (MCFC) and a gasifier on the same site to allow heat integration.

The biomass feed rate to each gasifier was set equal at 1,855 bone-dry $\mathrm{kg} / \mathrm{h}(4,080 \mathrm{lb} / \mathrm{h})$ to allow a comparison of the two configurations. The integrated gasifier-MCFC design had a net power output of 4.0 MW, compared to the stand-alone plant, which produced only $2.0 \mathrm{MW}$ of power, accounting for parasitic loads. The stand-alone plant supplying several individual PAFC units had a low electrical power conversion efficiency of $22 \%$ and had a thermal efficiency (combined electricity and heat utilization) of 54\%. The integrated plant had a higher electrical conversion efficiency of $43 \%$ because of tighter heat integration and the addition of a steam cycle to produce extra power from the waste heat.

The estimated capital cost of the stand-alone gasifier was $\$ 15$ million, including $\$ 4.8$ million for the fuel cells. For the integrated gasifier/fuel cell design, the total capital cost was estimated at $\$ 22$ million. The electricity selling prices, including depreciation and a $15 \%$ internal rate of return (IRR), were $\$ 0.47 / \mathrm{kWh}$ and $\$ 0.31 / \mathrm{kWh}$ for the stand-alone and integrated cases, respectively.

\subsection{FUEL CELL CHOICES}

Several alternative fuel cell designs are under development, each with its own specific benefits and disadvantages. Fuel cells operate by feeding a fuel, usually a hydrogen $\left(\mathrm{H}_{2}\right)$-rich stream, into the anode side of a gas-impermeable membrane while feeding an oxidant into the other cathode side of the membrane. On the cathode side, the oxidant breaks down into an ionic form that passes through the membrane by taking up electrons supplied through an external circuit. On the anode side, the fuel reacts with the ions coming through the membrane and gives up electrons to the external circuit. Because of the energy difference between the anode and cathode, there is a voltage difference and electrons flow from the anode to the cathode through the external circuit, producing electricity. The possible fuels vary depending on the fuel cell type, and each fuel cell has a specific range of operating temperatures (Hirschenhofer et al. 1994).

NASA has used alkaline fuel cells (AFCs) extensively in the space program for producing electricity from pure hydrogen and pure oxygen at a temperature of 200 (39E). Air cannot be used in AFCs because the carbon dioxide $\left(\mathrm{CO}_{2}\right)$ reacts with the electrolyte in the fuel cell. Pure hydrogen is required as the fuel because any $\mathrm{CO}_{2}$ or carbon monoxide (CO) from fossil fuels would poison the fuel cell (Hirschenhofer et al. 1994). Therefore, AFCs cannot be used in biomass applications without an oxygen generation plant and extensive gas purification. 
Polyelectrolyte membrane fuel cells (PEMs or PEMFCs) use a solid polymer membrane as the charge carrier in the fuel cell and are being developed mainly for transportation applications. The PEM fuel cells have the lowest operating temperature of any fuel cell, operating at $80^{\circ}$ (176). They can use air as an oxidant, but $\mathrm{CO}_{2}$ concentrations higher than $10 \mathrm{ppm}$ can poison PEM fuel cells (Hirschenhofer et al. 1994). In order to use synthesis gas, further purification using pressure swing adsorption or $\mathrm{H}_{2}$-permeable membranes would be required. A PEM fuel cell system would be very similar to the design used in a previous report (Mann 1995) to produce hydrogen using the BCL/FERCO gasifier.

Solid oxide fuel cells (SOFCs) have the advantage that they operate at high temperatures (650 $\left.1,00 \mathbb{C}^{\sim}\left[1,202^{\sim}-1,83 \mathrm{E}\right]\right)$ providing greater heat integration opportunities, but the high temperatures also create some construction- and material-related problems that still need to be solved. They can, however, be operated on air and CO-containing streams and could be an option in the future for biomass applications, (Hirschenhofer et al. 1994).

Phosphoric acid fuel cells are commercially available and typically operate on natural gas and air. PAFCs can be poisoned by high levels of $\mathrm{CO}$, but can operate effectively with $1 \%-2 \% \mathrm{CO}$ in the fuel feed. Because the units are currently available, they were used in the design for the standalone gasifier supplying synthesis gas to individual fuel cells. The only difference between the design included here and the commercial design is that the steam-reforming and water-gas-shift reactions are done at the gasifier site in the stand-alone design, instead of as a part of the fuel cell package. PAFCs operate at $20 \mathbb{E}^{-}(40 \boxminus)$ and can provide heat for hot water and household heating, if needed (Hirschenhofer et al. 1994).

For the integrated case, MCFCs were used. MCFCs operate at $650^{\sim}(1,20 \mathrm{E})$, which is high enough to produce steam from the waste heat. This steam can then be run through a steam cycle to produce electricity. MCFCs, like SOFCs, can use fuels containing $\mathrm{CO}$ and can use air as an oxidant. One unique requirement of MCFCs is that $\mathrm{CO}_{2}$ must be present in the cathode oxidant gas because the $\mathrm{CO}_{2}$ is used as a charge carrier in the fuel cell. In pure $\mathrm{H}_{2}$ hydrogen applications this can be a problem because an outside $\mathrm{CO}_{2}$ source is needed. In biomass or natural gas reforming applications, the spent fuel from the fuel cell, containing $\mathrm{CO}_{2}$ from fuel reforming and shift reactions, can be fed into the cathode.

For detailed information on each type of fuel cell, refer to Fuel Cell Handbook (Hirschenhofer et al. 1994).

\subsection{STAND-ALONE DESIGN}

The stand-alone gasifier design uses the same BCL/FERCO design used in prior studies (Craig and Mann 1996; Mann and Spath, 1997; Mann 1995). A recirculating sand bed acts as a heat carrier, taking heat from a char furnace and supplying it to the endothermic gasification reaction. The synthesis gas created by this process has a higher energy content than gas produced by air blown gasifiers because the gas is not diluted by nitrogen. 
The stand-alone design can be broken down into three sections: the gasifier, gas processing, and the PAFC unit. The gasifier section in the stand-alone design has been simplified with minimal heat integration to allow for operation in remote areas. Some of the raw synthesis gas is burned to heat the reformer reactor with the exhaust gases going to the gasifier wood dryer. The gas discharged from the gas processing section is under pressure, so no fuel compressor is needed for the fuel cell unit.

A detailed description of each section of the stand-alone gasifier design follows.

\subsection{Gasifier Section}

Figure 1 shows the flowsheet for the gasifier section of the stand-alone plant. Dry wood, hot sand, and low-pressure superheated steam are fed into a fluidized bed gasifier. The heat from the recirculating sand is the only heat source for the endothermic gasification reaction that converts the wood into a mixture of $\mathrm{CO}_{2}, \mathrm{CO}, \mathrm{H}_{2}, \mathrm{CH}_{4}$ and a variety of other hydrocarbons. A significant amount of char is also formed during the reaction.

The char, sand, and gas mixture leaves the gasifier and the synthesis gas is separated from the sand and char in a cyclone. The char and sand enter a char furnace, along with preheated combustion air where the char is burned to heat the sand. The combustion gas is then separated from the sand, which is returned to the gasifier. Some sand is continuously purged from the system to remove the small amount of ash that results. Fresh sand is added to the stream returning to the gasifier.

The combustion gas from the char furnace passes through an air heater to preheat the char furnace combustion air. This preheating allows higher gasification temperatures, increasing the gasifier yield. The hot combustion gases are directed to the wood dryer. The flue gases from the reformer burner in the gas processing section are also sent to the dryer. Because of the high temperature of the combustion gases, dilution air is added to reduce the gas temperature to $23 \mathrm{C}^{\sim}$ (45甘) before it enters the dryer. The outlet temperature of the dryer is kept above $10 \mathbb{E}(22 \forall)$ to prevent condensation of the water vapor. This moisture-laden air is released to the atmosphere after passing through a cyclone to capture fines and an electrostatic precipitator (ESP) to remove smaller particulate matter.

The hot synthesis gas passes through a superheater and boiler to produce the low-pressure steam for the gasifier. The synthesis gas then goes through a hot filtration system to remove any particulate matter and continues on to the gas processing section of the plant.

\subsection{Gas Processing}

Gas processing is required to convert the $\mathrm{CH}_{4}$ and higher hydrocarbons into $\mathrm{H}_{2}$ and to reduce the $\mathrm{CO}$ concentration to $1 \%-2 \%$ so it can be fed into a PAFC without poisoning the catalyst. Figure 2 shows the gas processing section of the stand-alone design. 
The gas is first compressed to provide the pressure needed to overcome the reformer and shift reactor pressure drops and to provide pressure to the gas distribution network. Some (15\%) of the raw gas is also sent to a small burner that provides heat to the endothermic steam-reforming reaction. The exhaust gas from the burner also heats the gas entering the reformer, produces the steam for the reforming reaction, preheats the combustion air for the burner, and provides some heat for drying the wood feed to the gasifier.

The synthesis gas that doesngo to the burner is mixed with low-pressure steam and passes through a preheater to recover heat from the gas leaving the reformer. The gas then passes through the reformer heater to bring the gas up to the reformer reactor temperature of $850^{\sim}$ $(1,56 \mathrm{E})$. The gas enters the reformer where the primary reaction is the conversion of $\mathrm{CH}{ }_{4}$ into $\mathrm{H}_{2}$ and $\mathrm{CO}$. The gas passes back through the hot side of the reformer preheater before entering the high-temperature shift reactor.

The high-temperature shift reaction takes advantage of the faster kinetics at a high temperature to convert $70 \%$ of the $\mathrm{CO}$ into $\mathrm{H}_{2}$ through a water-gas-shift reaction. Conversion is, however, limited by the reaction equilibrium, so the gas is cooled and passed through a second, lowtemperature shift reactor to convert most of the remaining $\mathrm{CO}$ to $\mathrm{H}_{2}$. The cooling between the high- and low-temperature shift reactors can be done using cooling water, or low-pressure steam can be generated.

After passing through the low-temperature shift reactor the gas passes through a condenser and a knock-out drum to remove excess water before going out to the distribution network and fuel cells.

\subsection{Phosphoric Acid Fuel Cells}

Phosphoric acid fuel cells that run off natural gas and air are currently available commercially. The typical size for such a unit is $200 \mathrm{~kW}$. For the purposes of this evaluation, the system was modeled as a single fuel cell stack, but output from each fuel cell stack can be chosen by varying the membrane surface area and number of fuel cells in the fuel cell stack. Figure 3 shows the flows for a PAFC.

The synthesis gas coming from the gas distribution network is already at a high enough pressure that no additional gas compression is needed. A compressor is required for the fuel cell air fed to the cathode of the PAFC. Also, the fuel cell stack must be cooled. This can be accomplished with cooling water, or low-pressure steam can be generated.

Because the gas leaving the PAFC cannot be completely used, it is mixed with the cathode gas, containing excess oxygen, and is sent through a catalytic oxidation unit to consume the remaining gas. The cathode gas is preheated using the oxidizer exhaust gas to increase the reaction temperature in the oxidizer. The exhaust passes through a heat exchanger to produce more hot water or steam before being released to the atmosphere. 
Figure 1- Stand-Alone Design Gasifier Flowsheet

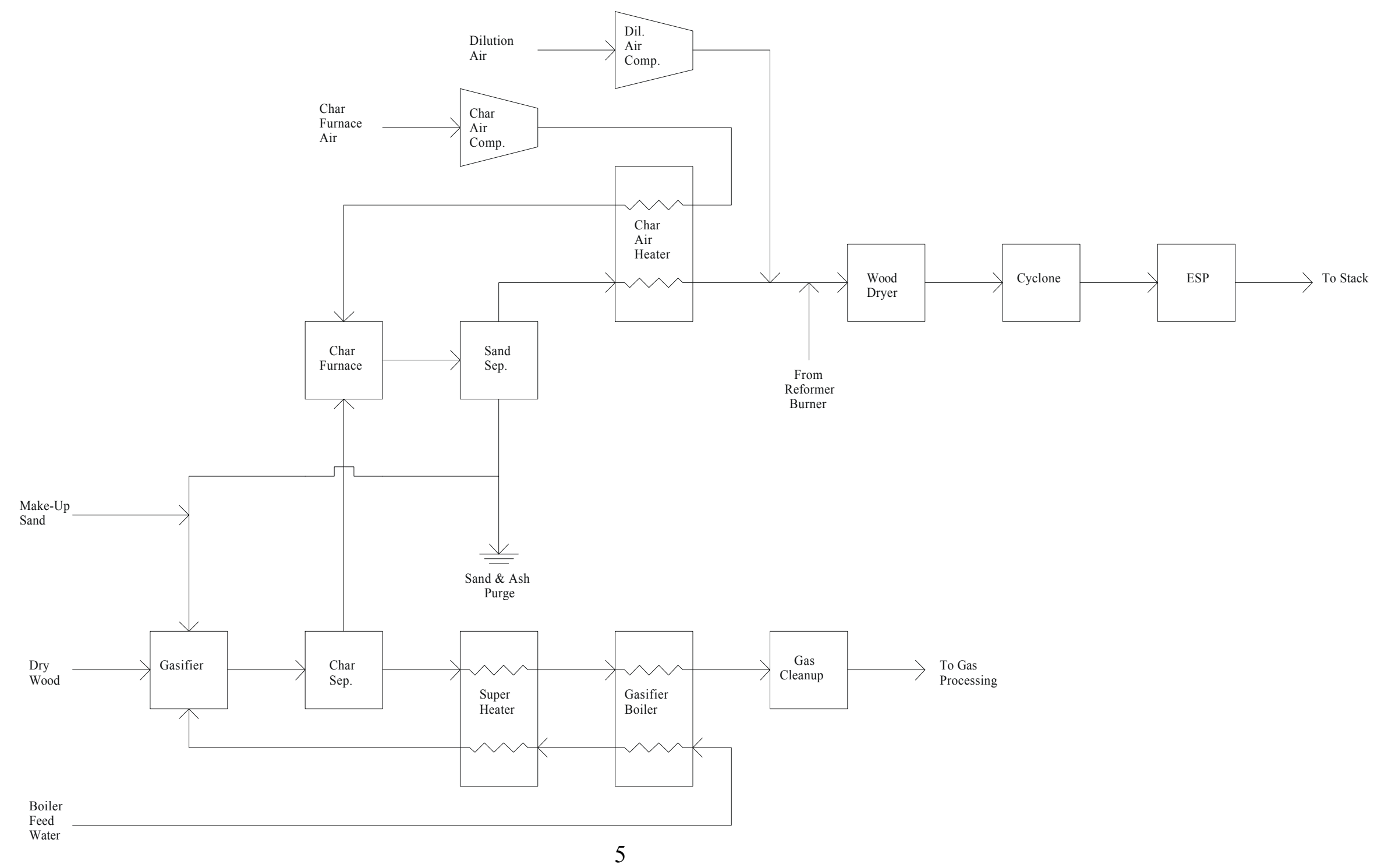


Figure 2 - Stand-Alone Design Gas Processing Section

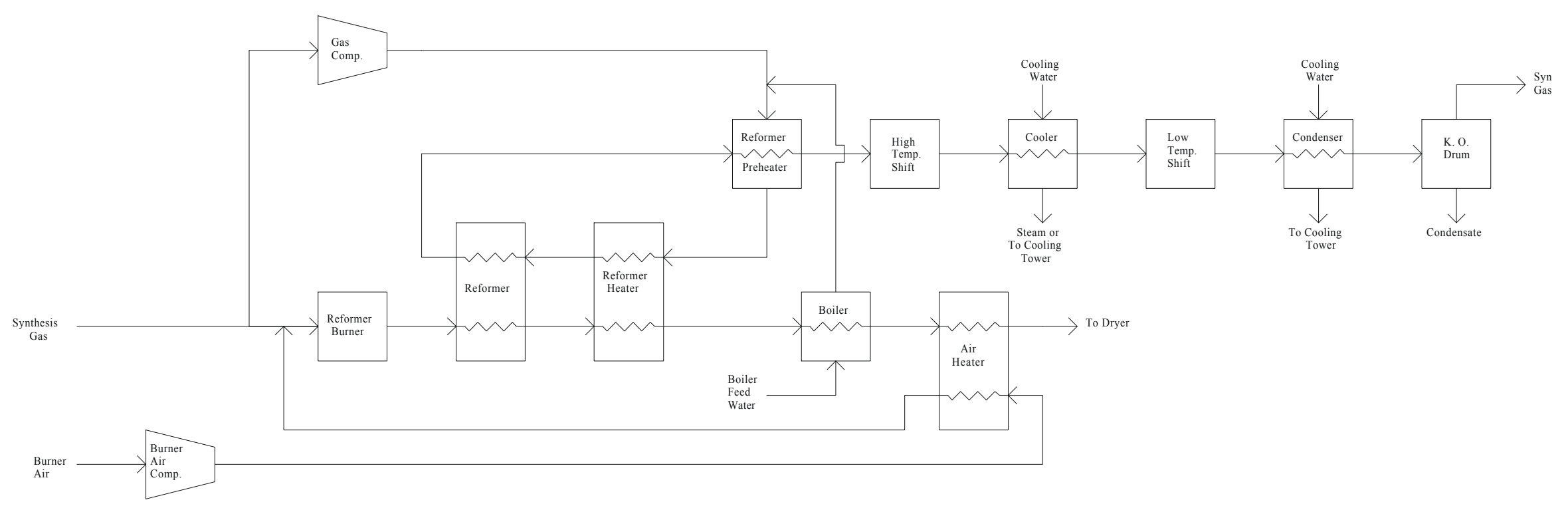


Figure 3 - Stand-Alone Design PAFC Flowsheet

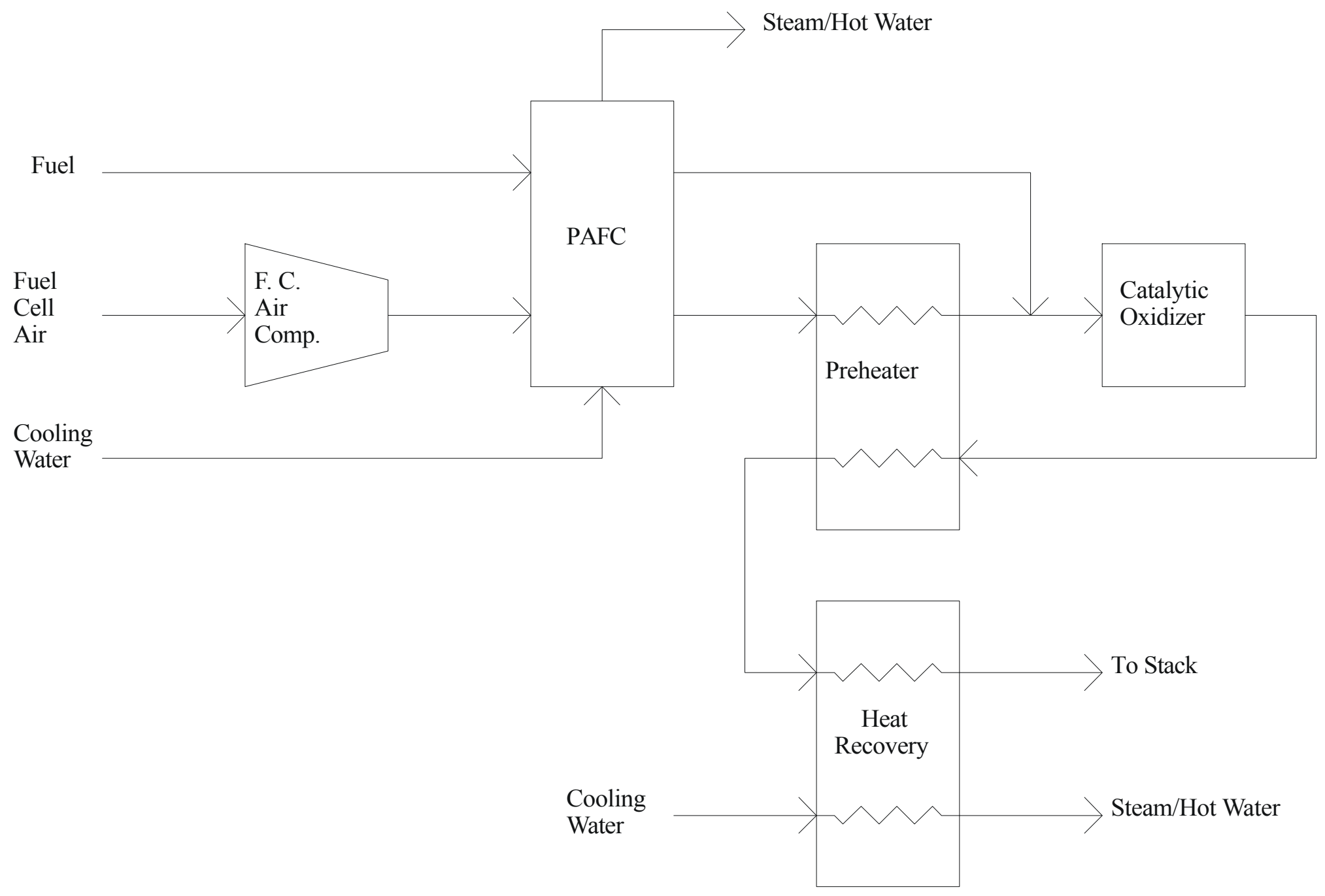


Information on the flowrates and stream compositions for the stand-alone gasifier can be found in Appendix B.

\subsection{INTEGRATED GASIFIER/FUEL CELL DESIGN}

The integrated gasifier/fuel cell design represents a more advanced system than the stand-alone case, taking advantage of more heat integration and using a steam cycle to produce additional electricity from the gasifier and fuel cell waste heat. The design has three distinct sections: the gasifier, the fuel cell section, and the steam cycle.

\subsection{The Integrated Gasifier}

The only difference between the integrated and stand-alone gasifier sections is the additional heat recovery from the char furnace gases. The flowsheet around the gasifier, char furnace and gas filtration remain the same. Figure 4 shows the integrated gasifier flowsheet.

The char furnace gases leaving the sand and ash separation step first pass through a steam superheater for the steam cycle before passing through the char furnace air heater. The combustion gases then enter a steam generator that produces $30 \%$ of the steam for the steam power cycle. The char furnace gases then are directed to the wood dryer, along with the exhaust gas from the MCFC and some dilution air, which is again used to keep the temperature of the incoming gases below the combustion temperature of the wood.

\subsection{Molten Carbonate Fuel Cell Section}

Figure 5 shows the MFCF section of the integrated plant. The synthesis gas passes through a preheater before entering a MCFC with internal reforming. In the simulation, the reformer and high-temperature shift reaction were modeled separately, but the heat required for reforming and the small amount of heat released during the shift reaction were combined with the heat from the fuel cell as if the reforming and shift reactions were occurring within the fuel cell. Mediumpressure steam is generated from the excess heat produced by the fuel cell.

The spent anode gas, containing some remaining fuel, is combined with air and sent through a catalytic oxidizer to consume the fuel. The exhaust gas from the oxidizer is used to preheat the incoming synthesis gas and is then combined with additional air and fed into the cathode side of the fuel cell. The exhaust gas from the catalytic oxidizer supplies the required $\mathrm{CO}_{2}$ for the MCFC reactions. The spent cathode oxidant stream is used to preheat the air to the fuel cell, then heat is recovered for the reheat step and economizer in the steam cycle. After heat recovery, the flue gas is sent to the wood dryer to take advantage of the remainder of the heat in the gas. 


\subsection{Steam Cycle}

Figure 6 shows the steam power cycle used to produce additional power from the waste heat in the integrated design. The steam cycle consists of an economizer, a medium pressure boiler (500 psig, $[3,500 \mathrm{kPa}]$ ), a superheater, a medium-pressure turbine, steam extraction for the reformer, a reheat step, a low-pressure turbine, and a condenser.

The heat for the economizer comes from the fuel cell exhaust gas. Two sections generate steam for the steam cycle: the exhaust from the char furnace, and the MCFC. The superheating comes from the char furnace combustion gas, and the heat for the reheat step comes from the fuel cell exhaust gas. The condenser has an operating pressure and temperature of $20 \mathrm{kPa}(3 \mathrm{psia})$ and $6 \mathbb{C}^{\sim}(14 \mathrm{~B})$ based on the cooling water outlet temperature of $5 \mathbb{Q}^{\sim}(12 \mathrm{E})$.

Flowrate data and stream compositions for the integrated power plant design can be found in Appendix B.

\subsection{STAND-ALONE PERFORMANCE AND COST}

The stand-alone gasifier has minimal heat integration, but includes the gas processing section to use the $\mathrm{CH}_{4}$ in the synthesis gas and to limit $\mathrm{CO}$ fed to the PAFC. Some power conversion efficiency is lost because the gasifier doesnc̃apture all the waste heat released. Some of the synthesis gas produced is diverted to the reformer burner, but much of this heat goes into increasing the heating value of the reformed gas and is not lost.

\subsection{Stand-Alone Gasifier Cost}

The total capital cost of the stand-alone gasifier was estimated to be $\$ 15$ million. The operating costs for the stand-alone plant are $\$ 3.2 \mathrm{million} / \mathrm{yr}$. Including depreciation and a $15 \%$ discounted cash flow factor, the electricity price is $\$ 0.47 / \mathrm{kWh}$. The depreciation period for the gasifier was 5 years with a 15 year depreciation period for the fuel cells.

The details of the economic calculations can be found in Appendix A.

\subsection{Stand-Alone Gasifier Efficiency and Heat Availability}

As mentioned before, the electric generating efficiency for the stand-alone case is $22 \%$, based on a biomass feed rate of 1,855 bone-dry $\mathrm{kg} / \mathrm{h}(4,080 \mathrm{lb} / \mathrm{h})$ and net power production of $2.0 \mathrm{MW}$. However, significant energy can be recovered from the PAFC, plus some steam can be generated in the gas processing section at the gasification site. The amount of heat available for steam or water heating from the PAFC is $10.7 \mathrm{GJ} / \mathrm{h}(10.3 \mathrm{MM} \mathrm{Btu} / \mathrm{h})$, which combined with the electricity production increases the overall thermal efficiency of the process to $54 \%$. 
Figure 4 - Integrated System Gasifier Flowsheet

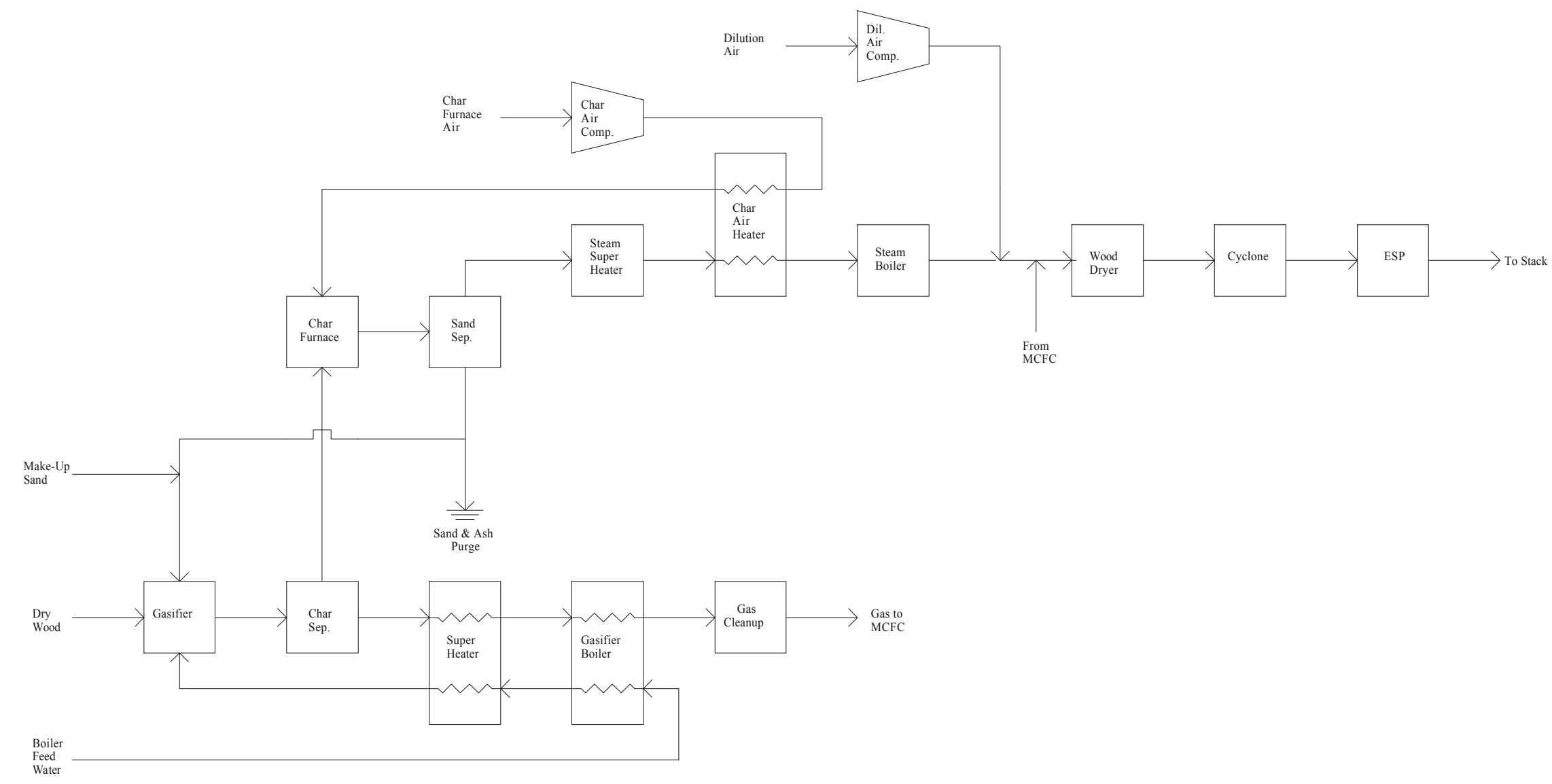


Figure 5 - Integrated System MCFC Flowsheet

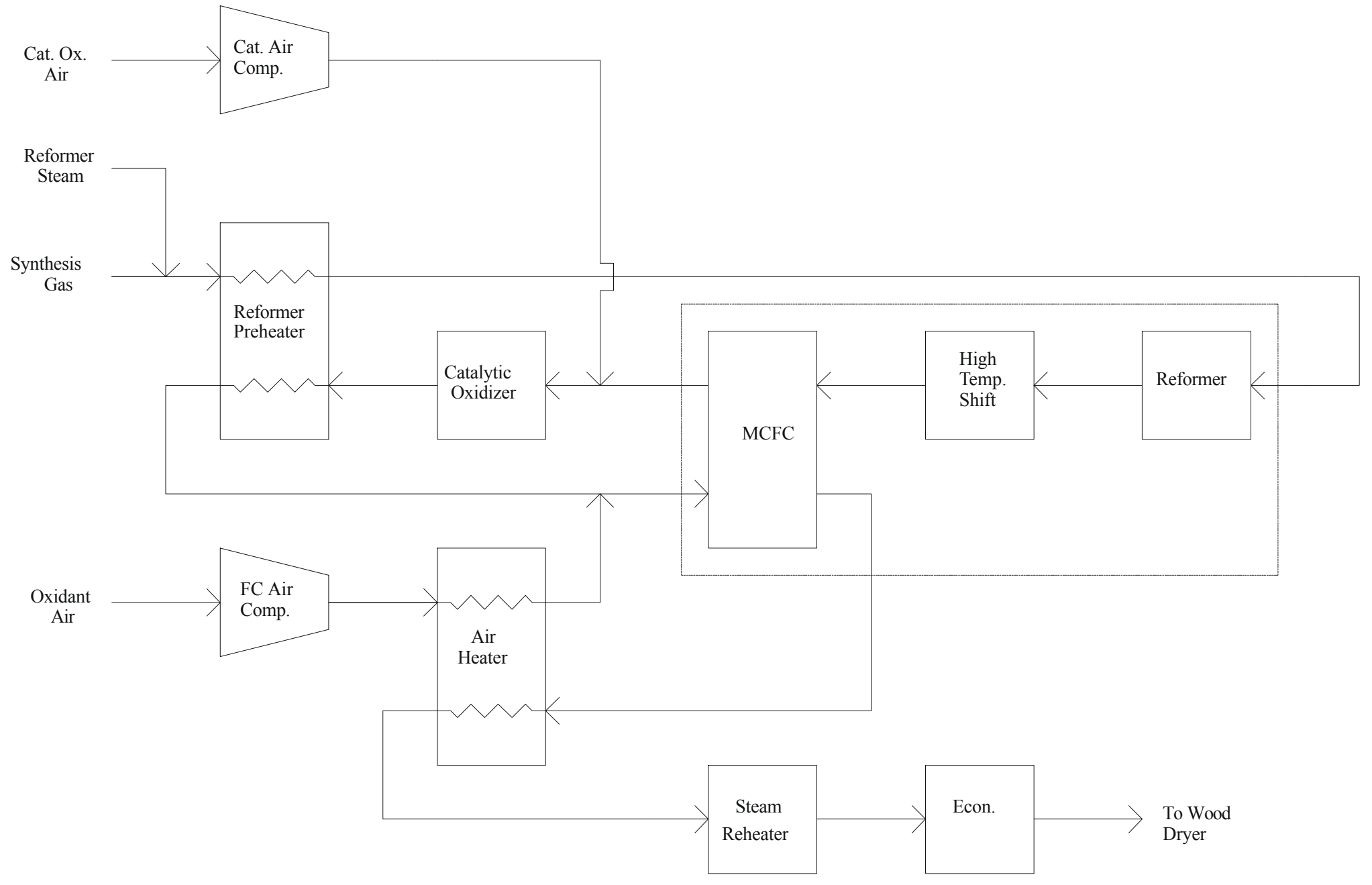


Figure 6 - Integrated System Steam Cycle

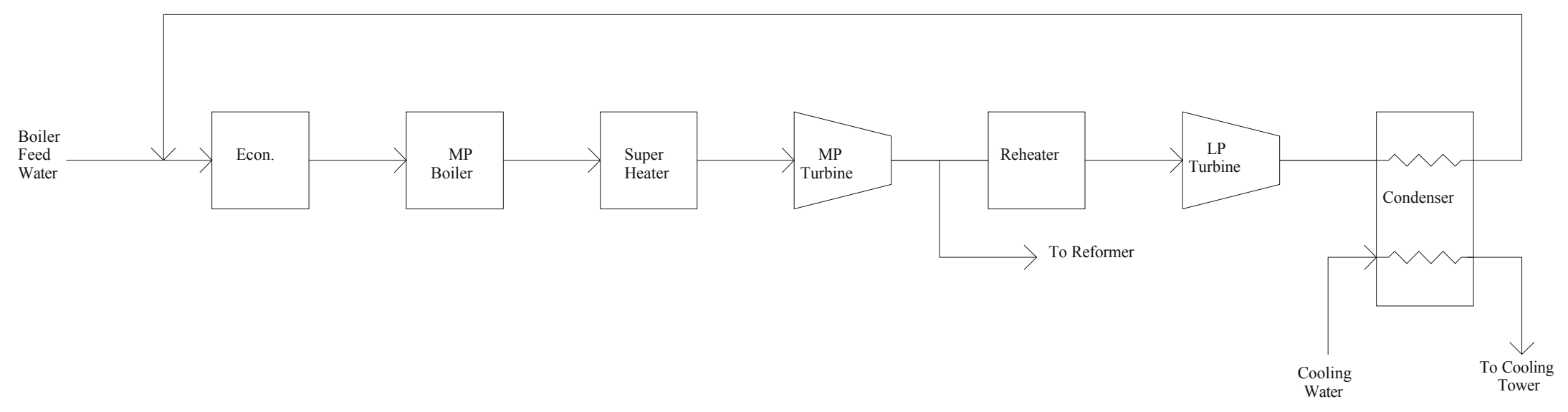




\subsection{INTEGRATED PERFORMANCE AND COST}

The integrated plant has more heat integration and therefore higher capital costs, but the electric conversion efficiency of the plant is much higher. No hot water or steam was made available in the integrated design; all available waste heat is instead used in a steam bottoming cycle.

\subsection{Integrated System Cost}

The total capital cost of the integrated gasifier was estimated to be $\$ 22$ million. The operating costs for the integrated plant are $\$ 3.9$ million/yr. Including depreciation and a $15 \%$ discounted cash flow factor, the price of electricity is $\$ 0.31 / \mathrm{kWh}$. A depreciation period of 20 years was used for the steam section of the power plant. Details of the economic calculations for the integrated system can be found in Appendix A.

\subsection{Integrated System Efficiency}

As expected, the integrated system efficiency was higher than that of the stand-alone case. Net electric production efficiency was $43 \%$. This is based on the same wood feed rate as the standalone case of 1,855 bone-dry $\mathrm{kg} / \mathrm{h}(4,080 \mathrm{lb} / \mathrm{h})$. The net power from the integrated system was 4.0 MW. Of this output, 0.7 MW comes from the steam cycle.

The integrated system efficiency is still considerably lower than the predicted fuel cell efficiency of $50 \%-60 \%$ for the MCFC, but there are several reasons for this. First, fuel utilization, or the amount of fuel converted to energy in the fuel cell, is not $100 \%$--some fuel passes through unreacted. Second, the reactant and oxidant concentrations to the fuel cell are diluted by nitrogen and other non-reacting gases, lowering the fuel cell voltage and efficiency. More complex gas purification and fuel recycling would improve the overall fuel utilization and increase the efficiency, but would also increase the capital costs.

\subsection{DESIGN CONSIDERATIONS}

Like most power plants, much of the heat lost from the system is heat associated with the flue gas and condenser. In both designs some of the flue gas waste heat is used to dry the wood feed, but this still represents a great deal of lost energy, which could be used elsewhere in the process if drying were not required.

Another flue gas issue unique to the fuel cells is the large amount of excess air that is heated in the fuel cell. A power boiler might use 30\%-50\% excess air, but fuel cells typically have only $50 \%$ oxidant utilization, which means there is $100 \%$ excess air. In high temperature fuel cells such as the MCFC, even with heat recovery, a large amount of heat can leave the system with the spent oxidant. 
Fuel utilization is a double-edged sword in the design of integrated systems. In order to take advantage of the high energy efficiency of fuel cells, it is desirable to have as much fuel as possible reacted using the fuel cell. However, if the single-pass utilization is high, the outlet concentration in the fuel will be low, causing the cell voltage to be low, reducing the efficiency. Also, if the spent fuel is to be burned to supply heat to other processes, such as reforming, high fuel utilization means less fuel to burn, and a lower gas temperature leaving the burner or catalytic oxidizer. One way to improve the overall system efficiency is to have low single-pass fuel utilization, but good recovery and separation of the unreacted fuel to recycle it back to the fuel cell inlet. This, however, increases the complexity and cost of the system.

Heat integration was also difficult in the designs because several areas needed high temperature heat sources, but only low-temperature waste heat was available. The high heat duty and high temperature requirements of the steam reformer is one example. In the stand-alone design, some of the raw synthesis gas must be burned to meet the reformer heat requirement.

\subsection{FUEL CELL COSTS}

For the stand-alone PAFC design, the assumed price of a fuel cell stack was $\$ 2,000 / \mathrm{kW}$. The current price of International Fuel Cek $200 \mathrm{~kW}$ PC-25 fuel cell system is $\$ 600,000$ or $\$ 3,000 / \mathrm{kW}$ (Appleby 1996). This unit includes an onboard reformer. Because a reformer is included in the stand-alone gasifier gas processing section, the fuel cell stack cost would be about one-third less, or $\$ 2000 / \mathrm{kW}$.

For the MCFC integrated fuel cell case, a fuel cell cost of $\$ 3,000 / \mathrm{kW}$ was used. It was assumed that the MCFC stack was configured for internal reforming, so no additional costs were included for a reformer or shift reactor in the integrated plant design.

Projected fuel cell costs and cost goals vary, but to help assess the future outlook of an integrated gasifier/fuel cell facility, a fuel cell cost of $\$ 1,000 / \mathrm{kW}$ was assumed. This brought the capital cost of the stand-alone design down to $\$ 12$ million and gave a electricity price of $\$ 0.42 / \mathrm{kWh}$. For the integrated design, the estimated capital cost dropped to $\$ 15$ million with a electricity price of $\$ 0.24 / \mathrm{kWh}$.

One issue with using a per-kilowatt fuel cell cost is that changing fuel cell operating conditions to minimize the number of individual fuel cells will not have the proper effect on the fuel cell cost. For fuel cells, the production costs are directly related to the number of fuel cell assemblies required, and by operating under different conditions, such as higher current densities, the number of fuel cell assemblies can be reduced, usually at the expense of higher operating costs, (Hirschenhofer et al. 1994). However, with a fixed per-kilowatt cost, the proper break-even analysis between decreased capital costs and increased operating expenses cannot be done. A membrane assembly cost, which would allow more accurate cost estimates and optimization of fuel cell designs, is needed 


\subsection{WOOD COSTS}

The assumed cost for the wood for both process designs was $\$ 46 /$ bone dry tonne ( $\$ 42 /$ ton). The fuel cost for forest residue is closer to $\$ 19 /$ bone dry tonne ( $\$ 17 /$ ton). Using the forest residue cost reduces the stand-alone and integrated electricity prices to $\$ 0.45 / \mathrm{kWh}$ and $\$ 0.30 / \mathrm{kWh}$ using current fuel cell costs. With the expected reductions in fuel cell costs, the electricity price drops to $\$ 0.40 / \mathrm{kWh}$ and $\$ 0.22 / \mathrm{kWh}$ for the stand-alone and integrated cases, respectively. These savings are small because the fuel cost is low compared to the capital related costs.

\subsection{CONCLUSIONS}

The $43 \%$ efficiency of producing power using an integrated gasifier/fuel cell system is much higher than the efficiency of a combustion boiler using the same fuel. In the case of the standalone plant, the electric conversion efficiency was only $22 \%$, but the PAFC provided $10.7 \mathrm{GJ} / \mathrm{h}$ $(10.3 \mathrm{MM} \mathrm{Btu} / \mathrm{h})$ for home heating. This heat brings the thermal efficiency of the process to $54 \%$.

The electricity price for the stand-alone and integrated systems were $\$ 0.47 / \mathrm{kWh}$ and $\$ 0.31 / \mathrm{kWh}$, respectively. This includes depreciation and a $15 \%$ rate of return. With a $0 \%$ pre-tax rate of return, representing the situation where the primary concern is providing power, and not profiting from its sale, the prices for the stand-alone and integrated systems would be $\$ 0.24 / \mathrm{kWh}$ and $\$ 0.15 / \mathrm{kWh}$. Using the future fuel cell cost of $\$ 1,000 / \mathrm{kW}$ and wood residue, the stand-alone electricity price drops to $\$ 0.40 / \mathrm{kWh}$, and $\$ 0.19 / \mathrm{kWh}$ with $0 \%$ pre-tax IRR. For the integrated case, the electricity price is $\$ 0.22 / \mathrm{kWh}$ with a $15 \%$ after-tax IRR and a price of $\$ 0.11 / \mathrm{kWh}$ for a $0 \%$ after-tax rate of return. These results are summarized in Table 1. 
Table 1 - Summary of Biomass Gasification/Fuel Cell Costs

\begin{tabular}{|l|l|l|l|l|}
\hline & $\begin{array}{l}\text { Stand-Alone, } \\
\text { Current Costs }\end{array}$ & $\begin{array}{l}\text { Stand-Alone, } \\
\text { Future Costs }\end{array}$ & $\begin{array}{l}\text { Integrated, } \\
\text { Current Costs }\end{array}$ & $\begin{array}{l}\text { Integrated, } \\
\text { Future Costs }\end{array}$ \\
\hline $\begin{array}{l}\text { Total Fixed Costs } \\
\text { for Gasifier }\end{array}$ & $\$ 9.9$ million & $\$ 9.9$ million & $\$ 8.4$ million & $\$ 8.4$ million \\
\hline $\begin{array}{l}\text { Total Fixed Costs } \\
\text { for Fuel Cells }\end{array}$ & $\$ 4.8$ million & $\$ 2.4$ million & $\$ 11.2$ million & $\$ 3.7$ million \\
\hline $\begin{array}{l}\text { Total Fixed Costs for } \\
\text { Turbine }\end{array}$ & No Turbine & No Turbine & $\$ 2.5$ million & $\$ 2.5$ million \\
\hline $\begin{array}{l}\text { Total Fixed Capital } \\
\text { Investment }\end{array}$ & $\$ 14.7$ million & $\$ 12.3$ million & $\$ 22.1$ million & $\$ 14.6$ million \\
\hline $\begin{array}{l}\text { Annual Operating } \\
\text { Costs Using Wood }\end{array}$ & $\$ 3.2$ million & $\$ 3.0$ million & $\$ 3.9$ million & $\$ 3.2$ million \\
\hline $\begin{array}{l}\text { Annual Operating } \\
\text { Costs Using Residues }\end{array}$ & $\$ 2.8$ million & $\$ 2.4$ million & $\$ 3.5$ million & $\$ 2.8$ million \\
\hline $\begin{array}{l}\text { Electricity Price } \\
\text { Using Wood }\end{array}$ & $\$ 0.47 / \mathrm{kWh}$ & $\$ 0.42 / \mathrm{kWh}$ & $\$ 0.31 / \mathrm{kWh}$ & $\$ 0.24 / \mathrm{kWh}$ \\
\hline $\begin{array}{l}\text { Electricity Price } \\
\text { Using Residues }\end{array}$ & $\$ 0.45 / \mathrm{kWh}$ & $\$ 0.40 / \mathrm{kWh}$ & $\$ 0.30 / \mathrm{kWh}$ & $\$ 0.22 / \mathrm{kWh}$ \\
\hline $\begin{array}{l}\text { Price with } 0 \% \text { Return } \\
\text { and Wood }\end{array}$ & $\$ 0.24 / \mathrm{kWh}$ & $\$ 0.22 / \mathrm{kWh}$ & $\$ 0.15 / \mathrm{kWh}$ & $\$ 0.12 / \mathrm{kWh}$ \\
\hline $\begin{array}{l}\text { Price with } 0 \% \text { Return } \\
\text { and Residues }\end{array}$ & $\$ 0.21 / \mathrm{kWh}$ & $\$ 0.19 / \mathrm{kWh}$ & $\$ 0.14 / \mathrm{kWh}$ & $\$ 0.11 / \mathrm{kWh}$ \\
\hline
\end{tabular}

\subsection{FUTURE WORK}

Although the integrated case uses much of the waste heat available, sensitivity analysis of various fuel and oxidant utilization rates and adjustment of operating temperatures for some equipment should be investigated for both system designs. These studies would require careful checks of the different heat integration sections whenever a change is made because a small change in something like fuel utilization can have a large effect on the waste heat available in the process.

One problem with the economic analysis was the uncertainty of some of the equipment estimates. Much work has been done in determining fuel cell efficiencies, but the current and projected costs of both the gasifier and fuel cells are uncertain. Even in the case of the PAFC, where a market price is available, it was not possible to estimate the effect fuel cell operational changes 
would have on capital costs since most cost estimates are given on a per $\mathrm{kW}$ basis and not per membrane basis.

Capital costs for the gasifier were also not reliable since it is not commercially available, but hopefully with the results from the U. S. Department of Energy BCL/FERCO gasifier demonstration in Burlington, Vermont, better cost data will become available. 


\section{REFERENCES AND PERTINENT LITERATURE}

Appleby, A.J. (1996).Iñsues in Fuel Cell Commercialization. Journal of Power Sources. Vol. 69, pp. 153-176.

Caruanna, C.M. (September 1996).Fũel Cells Poised to Provide Power.Chemical Engineering Progress.

Cooper, C.D.; Alley, F.C. (1994). Air Pollution Control. 2nd edition. Prospect Heights, IL: Waveland Press, Inc.

Craig, K.R.; Mann, M.K. (October 1996). Cost and Performance Analysis of Biomass-Based Integrated Gasification Combined-Cycle (BIGCC) Power Systems. NREL/TP-430-21657. Golden, CO: National Renewable Energy Laboratory.

Garrett, D.E. (1989). Chemical Engineering Economics. New York: Van Nostrand Reinhold.

Geankoplis, C.J. (1983). Transport Processes and Unit Operations. 2nd edition. Boston: Allyn and Bacon, Inc.

Gilbert, B.R.; Nawaz, M.; Chen, T.P. (August 1995).Fũel Cells Make Their CPI Moves. Chemical Engineering.

Hirschenhofer, J.H.; Stauffer, D.B.; Engleman, R.R. (January 1994). Fuel Cell Handbook. DOE/METC-94/1004

Huijsmans, J.P.PEñergy and Fuel Cells.ECN Fossil Fuels.

Joon, K. (1996).Critical Issues and Future Prospects for the Molten Carbonate Fuel Cells. Journal of Power Sources. Vol. 61, pp. 129-133.

Mann, M.K. (August 1995). Technical and Economic Assessment of Producing Hydrogen by Reforming Syngas from the Battelle Indirectly Heated Biomass Gasifier.

NREL/TP-431-8143. Golden, CO: National Renewable Energy Laboratory.

Mann, M.K.; Spath, P.L. (December 1997). Life Cycle Assessment of a Biomass Gasification Combined-Cycle Power System. NREL/TP-430-23076. Golden, CO: National Renewable Energy Laboratory.

MCFC Power Plant System Verification. DE-AC21-90MC27168. Work performed by Energy Research Corp.

Natural Gas Fuel Cells.Technical Technology Alert. U.S. Department of Energy.

Peters, M.S.; Timmerhaus, K.D. (1991). Plant Design and Economics for Chemical Engineers. 
4th edition. New York: McGraw-Hill, Inc.

Putsche, V.L. (1998) Molten Carbonate Fuel Cell (MCFC) Model Documentation and Sensitivity Studies. Work performed for National Renewable Energy Laboratory.

Putsche, V.L. (1998) Phosphoric Acid Fuel Cell (PAFC) Model Documentation and Sensitivity Studies. Work performed for National Renewable Energy Laboratory.

Tarman, P.B. (1994). "Overview of the IMHEX Commercialization Strategy." Fuel Cell '94 Contractors Review Meeting; August 17-18, 1994, Morgantown, WV. 


\section{APPENDIX A - ECONOMIC CALCULATIONS}

Appendix A contains spreadsheets that detail the capital and operating cost estimates. The eight cases examined are summarized in Table A0. For each case, a calculation was also performed for a zero pre-tax rate of return for cases where power is generated at cost.

Table A0 - Summary of the eight cases examined.

\begin{tabular}{|l|c|c|c|l|c|c|}
\hline & Wood & Residue & $\begin{array}{l}\text { Current } \\
\text { FC Cost }\end{array}$ & $\begin{array}{l}\text { Future } \\
\text { FC Cost }\end{array}$ & $\begin{array}{l}\text { Stand- } \\
\text { Alone }\end{array}$ & Integrated \\
\hline Case 1 & $\mathrm{X}$ & & $\mathrm{X}$ & & $\mathrm{X}$ & \\
\hline Case 2 & $\mathrm{X}$ & & $\mathrm{X}$ & & & $\mathrm{X}$ \\
\hline Case 3 & $\mathrm{X}$ & & & $\mathrm{X}$ & $\mathrm{X}$ & \\
\hline Case 4 & $\mathrm{X}$ & & & $\mathrm{X}$ & & $\mathrm{X}$ \\
\hline Case 5 & & $\mathrm{X}$ & $\mathrm{X}$ & & $\mathrm{X}$ & \\
\hline Case 6 & & $\mathrm{X}$ & $\mathrm{X}$ & & & $\mathrm{X}$ \\
\hline Case 7 & & $\mathrm{X}$ & & $\mathrm{X}$ & $\mathrm{X}$ & \\
\hline Case 8 & & $\mathrm{X}$ & & $\mathrm{X}$ & & $\mathrm{X}$ \\
\hline
\end{tabular}

Below is list of the tables in Appendix A, with a brief description of each one.

Table A1 - Capital costs for cases 1 and 5.

Table A2 - Capital costs for cases 2 and 6.

Table A3 - Capital costs for cases 3 and 7.

Table A4 - Capital costs for cases 4 and 8.

Table A5 - Variable operating costs for cases 1, 3, 5, and 7.

Table A6 - Variable operating costs for cases 2, 4, 6, and 8.

Table A7 - Internal rate of return calculation for case 1.

Table A8 - Internal rate of return calculation for case 2.

Table A9 - Internal rate of return calculation for case 3.

Table A10 - Internal rate of return calculation for case 4.

Table A11 - Internal rate of return calculation for case 5.

Table A12 - Internal rate of return calculation for case 6.

Table A13 - Internal rate of return calculation for case 7.

Table A14 - Internal rate of return calculation for case 8. 


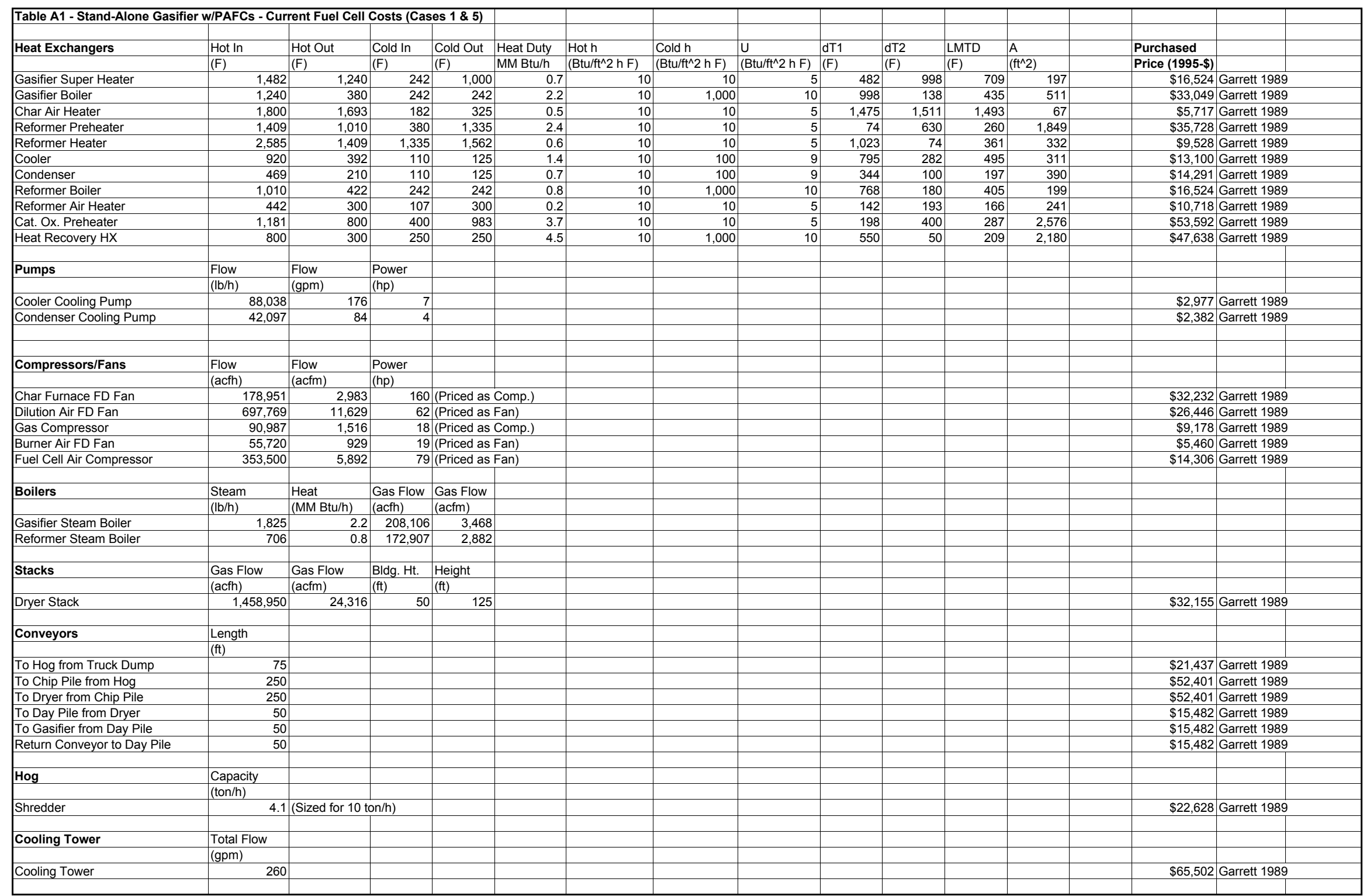




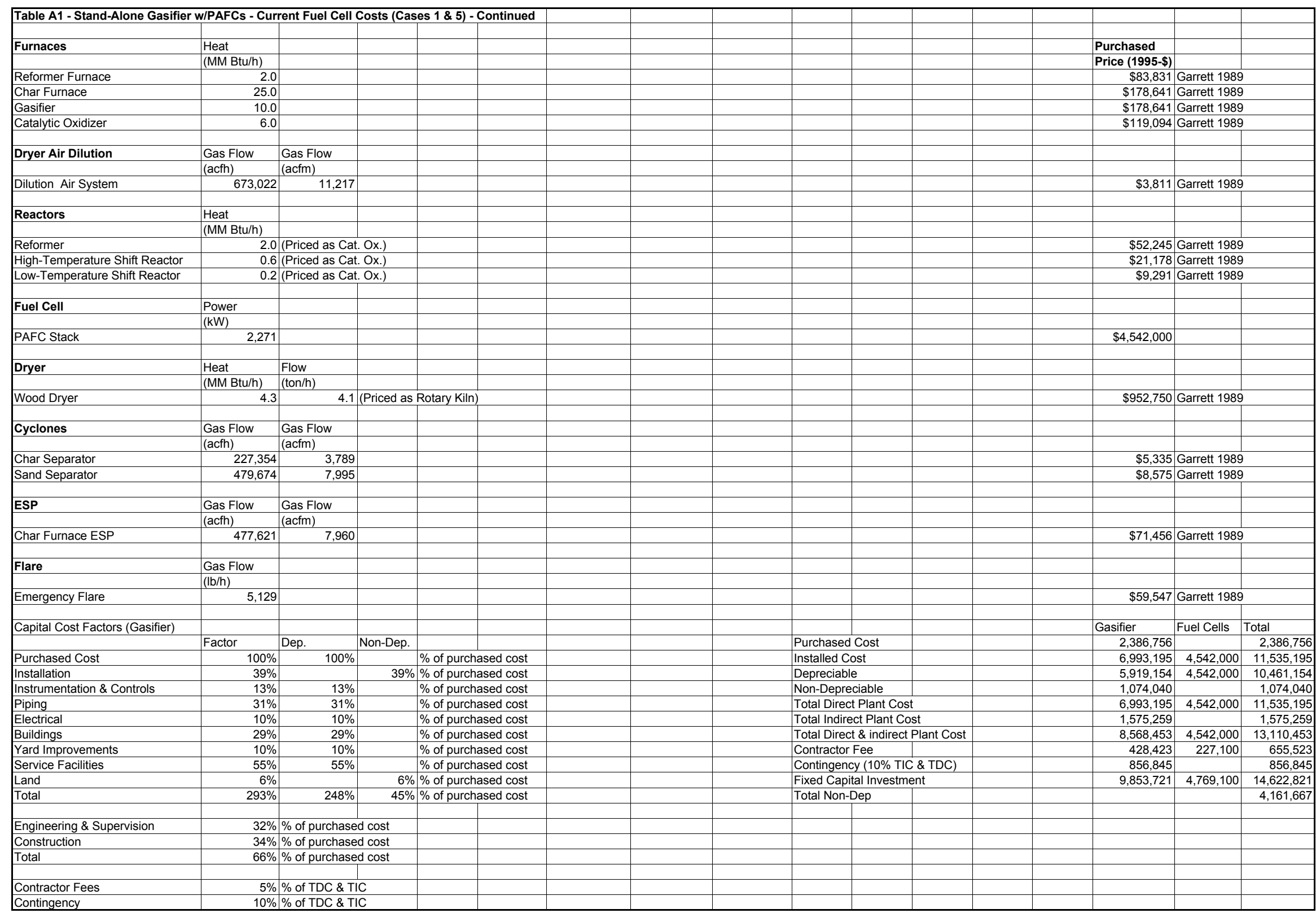




\begin{tabular}{|c|c|c|c|c|c|c|c|c|c|c|c|c|c|c|c|c|}
\hline \multicolumn{17}{|c|}{ Table A2 - Integrated Gasifier \& MCFC - Current Fuel Cell Costs (Cases 2 \& 6) } \\
\hline Heat Exchangers & Hot In & Hot Out & Cold In & Cold Out & Heat Duty & Hot $\mathrm{h}$ & Cold $\mathrm{h}$ & U & dT1 & dT2 & LMTD & A & Purchased & & Gasifier & Turbine \\
\hline & $(\mathrm{F})$ & (F) & (F) & & (MM Btu/h) & $\left(\mathrm{Btu} / \mathrm{ft}^{\wedge} 2 \mathrm{~h} \mathrm{~F}\right)$ & $\left(\mathrm{Btu} / \mathrm{ft}^{\wedge} 2 \mathrm{~h} F\right)$ & $\left(B t u / f t^{\wedge} 2 \mathrm{~h} \mathrm{~F}\right)$ & (F) & $(\mathrm{F})$ & & $\left(\mathrm{ft}^{\wedge} 2\right)$ & Price (1995- & -\$) & & \\
\hline Gasifier Super Heater & 1,500 & 1,262 & 242 & 1,000 & 0.7 & 10 & 10 & 5 & 500 & 1,020 & 729 & 192 & $\$ 16,524$ & Garrett 1989 & $\$ 16,524$ & \\
\hline Gasifier Boiler & 1,262 & 413 & 242 & 242 & 2.2 & 10 & 1,000 & 10 & 1,020 & 171 & 475 & 467 & $\$ 30,845$ & Garrett 1989 & $\$ 30,845$ & \\
\hline Char Air Heater & 1,639 & 1,472 & 182 & 400 & 0.7 & 10 & 10 & 5 & 1,239 & 1,290 & 1,264 & 111 & $\$ 5,955$ & Garrett 1989 & $\$ 5,955$ & \\
\hline Steam Super Heater & 1,800 & 1,639 & 470 & 619 & 0.7 & 10 & 10 & 5 & 1,181 & 1,169 & 1,175 & 119 & $\$ 11,457$ & Garrett 1989 & & $\$ 11,457$ \\
\hline Steam Boiler & 1,472 & 861 & 470 & 470 & 2.5 & 10 & 1,000 & 10 & 1,002 & 391 & 649 & 389 & $\$ 26,439$ & Garrett 1989 & & $\$ 26,439$ \\
\hline Reformer Pre-Heater & 1,568 & 1,287 & 398 & 1,202 & 2.4 & 10 & 10 & 5 & 366 & 889 & 589 & 814 & $\$ 27,392$ & Garrett 1989 & $\$ 27,392$ & \\
\hline Air Heater & 1,202 & 762 & 103 & 1,054 & 4.3 & 10 & 10 & 5 & 148 & 659 & 342 & 2,514 & $\$ 40,492$ & Garrett 1989 & $\$ 40,492$ & \\
\hline Steam Reheater & 762 & 672 & 362 & 589 & 0.8 & 10 & 100 & 9 & 173 & 310 & 235 & 375 & $\$ 26,439$ & Garrett 1989 & & $\$ 26,439$ \\
\hline Economizer & 672 & 507 & 139 & 300 & 1.5 & 10 & 100 & 9 & 372 & 368 & 370 & 446 & $\$ 28,642$ & Garrett 1989 & & $\$ 28,642$ \\
\hline \multirow[t]{2}{*}{ Condenser } & 145 & 145 & 110 & 125 & 7.9 & 10 & 1,000 & 10 & 20 & 35 & 27 & 29,768 & $\$ 275,063$ & Garrett 1989 & & $\$ 275,063$ \\
\hline & & & & & & & & & & & & & & & & \\
\hline \multirow[t]{2}{*}{ Pumps } & Flow & Flow & Power & & & & & & & & & & & & & \\
\hline & \begin{tabular}{|l|}
$(\mathrm{lb} / \mathrm{h})$ \\
\end{tabular} & (gpm) & (hp) & & & & & & & & & & & & & \\
\hline Boiler Feed Water Pump & 8,487 & 17 & 20 & & & & & & & & & & $\$ 7,717$ & Garrett 1989 & & $\$ 7,717$ \\
\hline Hot Well Pump & 7,561 & 15 & 1 & & & & & & & & & & $\$ 595$ & Garrett 1989 & & $\$ 595$ \\
\hline \multirow[t]{2}{*}{ Condenser Cooling Pump } & 520,628 & 1,040 & 33 & & & & & & & & & & $\$ 6,193$ & Garrett 1989 & & $\$ 6,193$ \\
\hline & & & & & & & & & & & & & & & & \\
\hline \multirow{2}{*}{ Compressors/Fans } & Flow & Flow & Power & & & & & & & & & & & & & \\
\hline & (acfh) & (acfm) & (hp) & & & & & & & & & & & & & \\
\hline Char Furnace FD Fan & 172,709 & 2,878 & 154 & & Comp.) & & & & & & & & $\$ 34,918$ & Garrett 1989 & $\$ 34,918$ & \\
\hline Dilution Air FD Fan & 290,897 & 4,848 & \multicolumn{3}{|c|}{$\frac{154 \text { (Prired as Comp.) }}{26 \text { (Priced as Fan) }}$} & & & & & & & & $\$ 9,237$ & Garrett 1989 & $\$ 9,237$ & \\
\hline Fuel Cell Air Compressor & 231,652 & 3,861 & \multirow{2}{*}{\multicolumn{3}{|c|}{$\begin{array}{l}74 \text { (Priced as Fan) } \\
34 \text { (Priced as Fan) }\end{array}$}} & & & & & & & & $\$ 12,183$ & Garrett 1989 & $\$ 12,183$ & \\
\hline \multirow[t]{2}{*}{ Cat. Ox. Air Compressor } & $\begin{array}{r}97,375 \\
9\end{array}$ & 1,623 & & & & & & & & & & & $\$ 7,269$ & Garrett 1989 & $\$ 7,269$ & \\
\hline & & & & & & & & & & & & & & & & \\
\hline \multirow[t]{2}{*}{ Turbines } & Power & & & & & & & & & & & & & & & \\
\hline & (hp) & & & & & & & & & & & & & & & \\
\hline MP Turbine & 335 & (Priced as Turk & bine \& Elec. & Motor) & & & & & & & & & $\$ 95,275$ & Garrett 1989 & & $\$ 95,275$ \\
\hline \multirow[t]{2}{*}{ LP Turbine } & 622 & (Priced as Turt & bine \& Elec. & Motor) & & & & & & & & & $\$ 131,003$ & Garrett 1989 & & $\$ 131,003$ \\
\hline & & & & & & & & & & & & & & & & \\
\hline \multicolumn{17}{|l|}{ Boilers } \\
\hline \multirow{2}{*}{\multicolumn{17}{|c|}{ Gasifier Steam Boiler }} \\
\hline & & & & & & & & & & & & & & & & \\
\hline Steam Cycle Boiler & & & & & & & & & & & & & & & & \\
\hline Fuel Cell Boiler & & & & & & & & & & & & & & & & \\
\hline & & & & & & & & & & & & & & & & \\
\hline Stacks & Gas Flow & Gas Flow & Bldg. Ht. & Height & & & & & & & & & & & & \\
\hline & (acfh) & $(\mathrm{acfm})$ & (ft) & (ft) & & & & & & & & & & & & \\
\hline Dryer Stack & $1,282,580$ & 21,376 & 50 & 125 & & & & & & & & & $\$ 32,155$ & Garrett 1989 & $\$ 32,155$ & \\
\hline & & & & & & & & & & & & & & & & \\
\hline Conveyors & Length & & & & & & & & & & & & & & & \\
\hline & & & & & & & & & & & & & & & & \\
\hline To Hog from Truck Dump & 75 & & & & & & & & & & & & $\$ 21,437$ & Garrett 1989 & $\$ 21,437$ & \\
\hline To Chip Pile from Hog & 250 & & & & & & & & & & & & $\$ 52,401$ & Garrett 1989 & $\$ 52,401$ & \\
\hline To Dryer from Chip Pile & 250 & & & & & & & & & & & & $\$ 52,401$ & Garrett 1989 & $\$ 52,401$ & \\
\hline To Day Pile from Dryer & 50 & & & & & & & & & & & & $\$ 15,482$ & Garrett 1989 & $\$ 15,482$ & \\
\hline To Gasifier from Day Pile & 50 & & & & & & & & & & & & $\$ 15,482$ & Garrett 1989 & $\$ 15,482$ & \\
\hline Return Conveyor to Day Pile & 50 & & & & & & & & & & & & $\$ 15,482$ & Garrett 1989 & $\$ 15,482$ & \\
\hline & & & & & & & & & & & & & & & & \\
\hline Hog & Capacity & & & & & & & & & & & & & & & \\
\hline & $(\operatorname{ton} / \mathrm{h})$ & & & & & & & & & & & & & & & \\
\hline Shredder & 4.1 & (Sized for 10 to & $o n / h)$ & & & & & & & & & & $\$ 22,628$ & Garrett 1989 & $\$ 22,628$ & \\
\hline & & & & & & & & & & & & & & & & \\
\hline Cooling Tower & Total Flow & & & & & & & & & & & & & & & \\
\hline & (gpm) & & & & & & & & & & & & & & & \\
\hline Cooling Tower & 1,040 & & & & & & & & & & & & $\$ 71,456$ & Garrett 1989 & \begin{tabular}{|l|l}
$\$ 11,456$ \\
\end{tabular} & \\
\hline
\end{tabular}




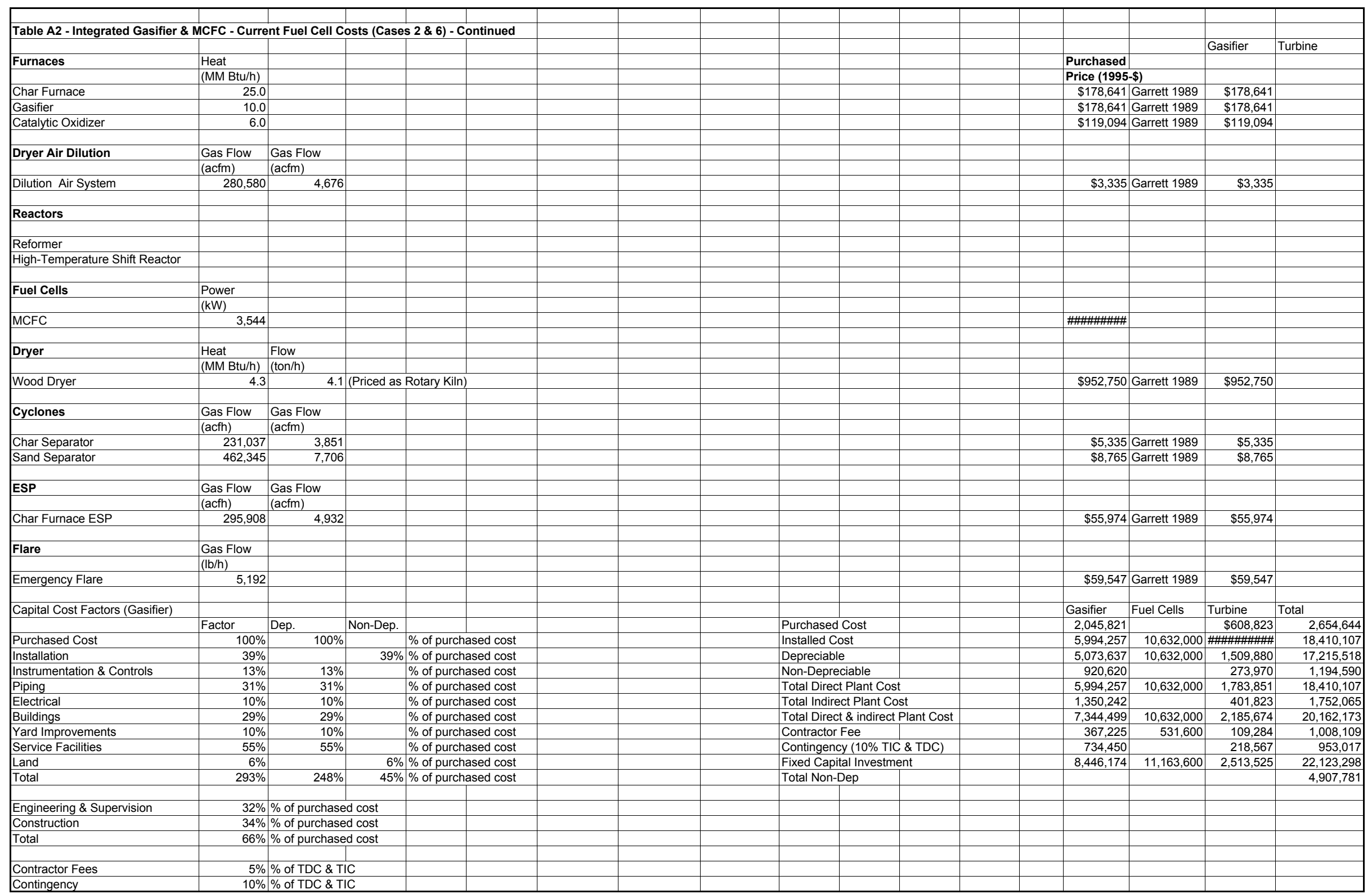




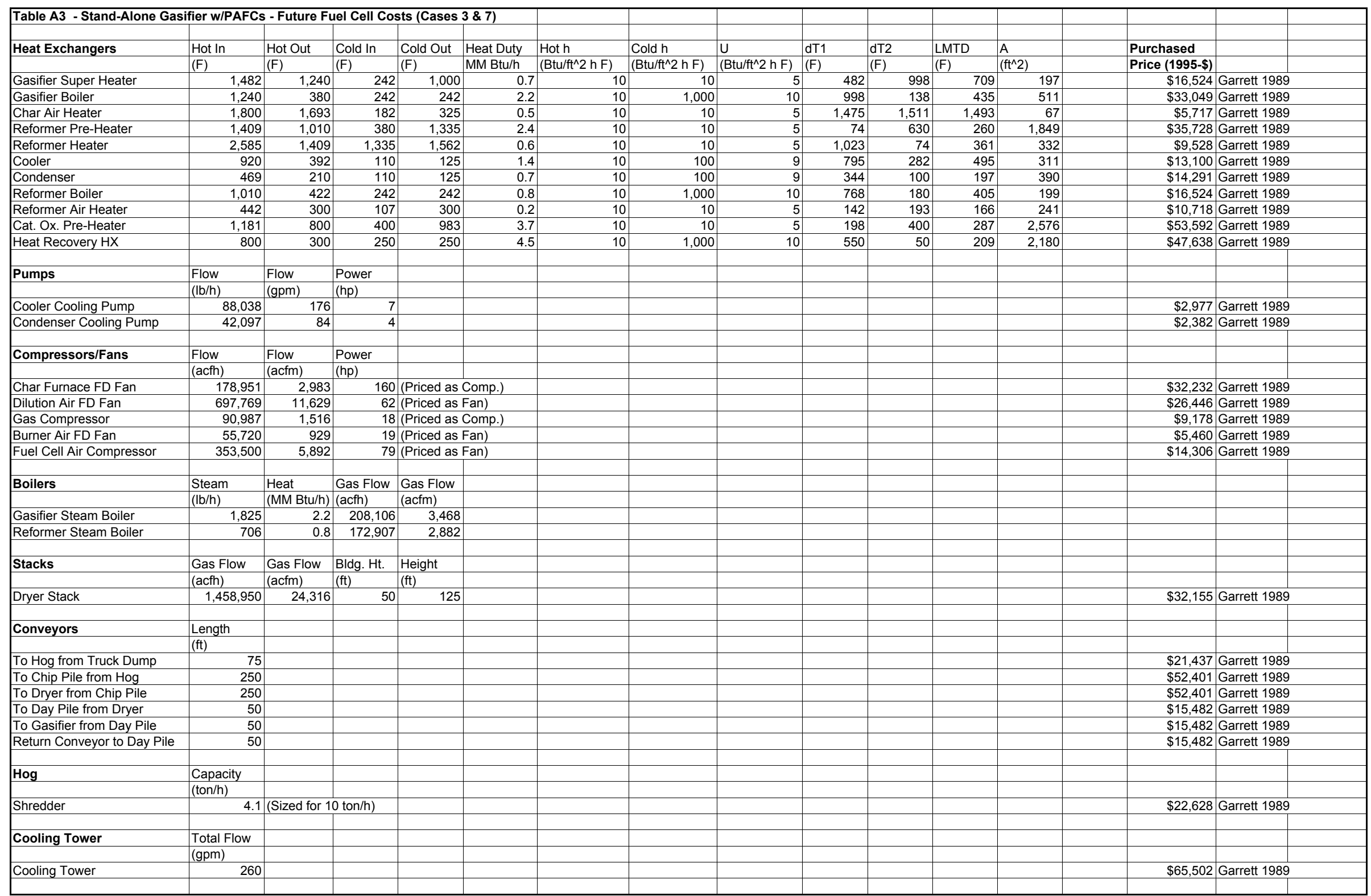




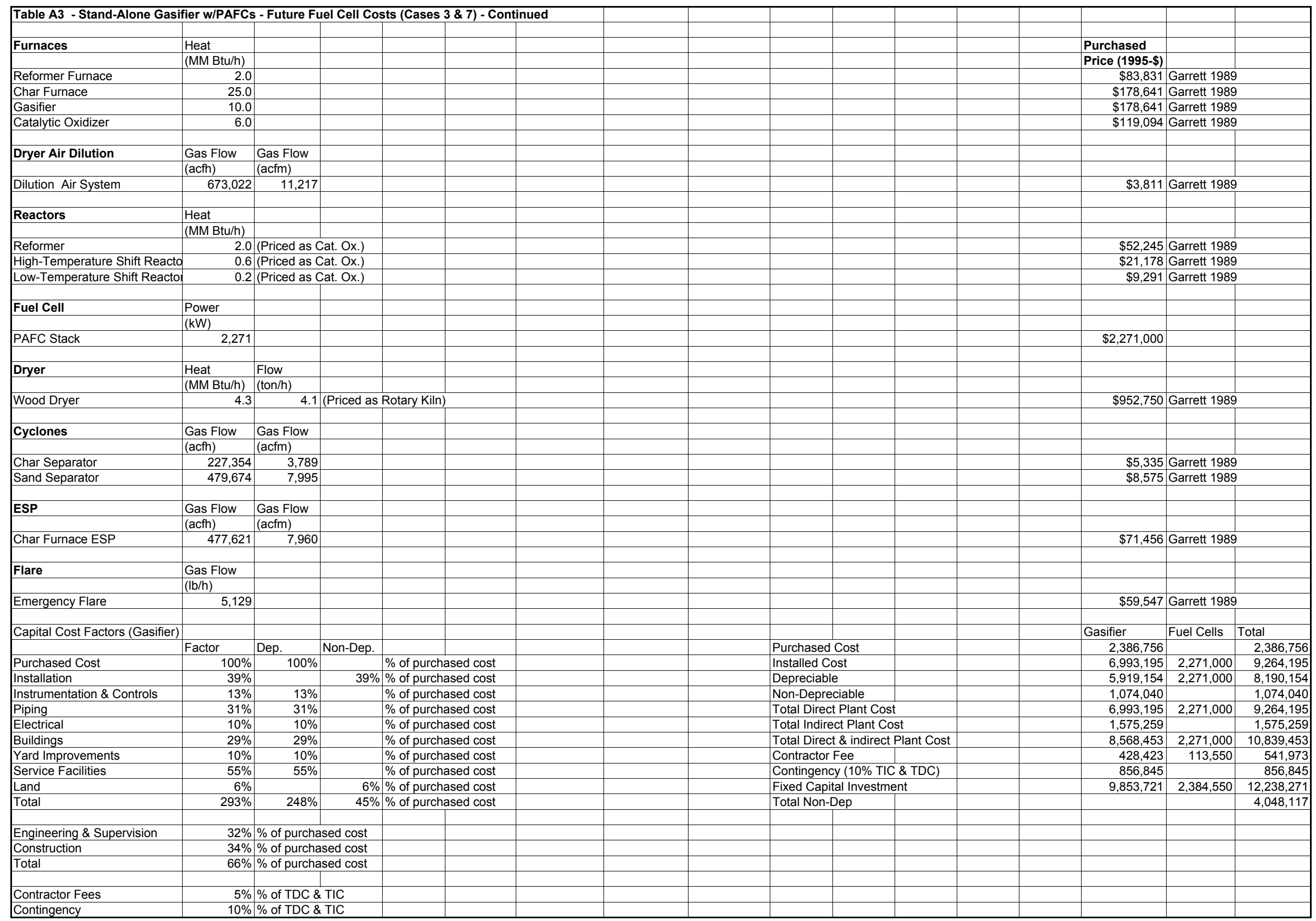




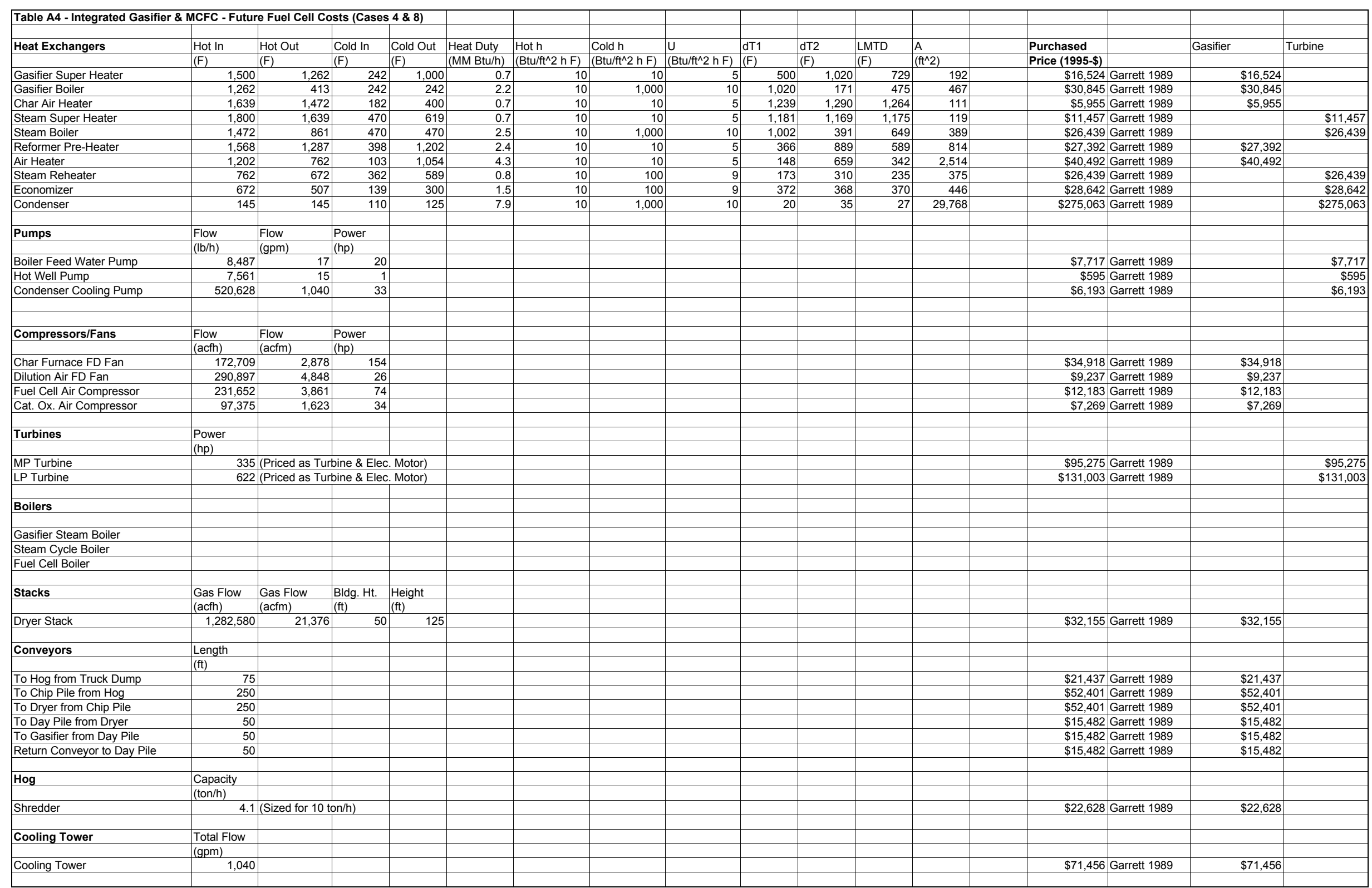




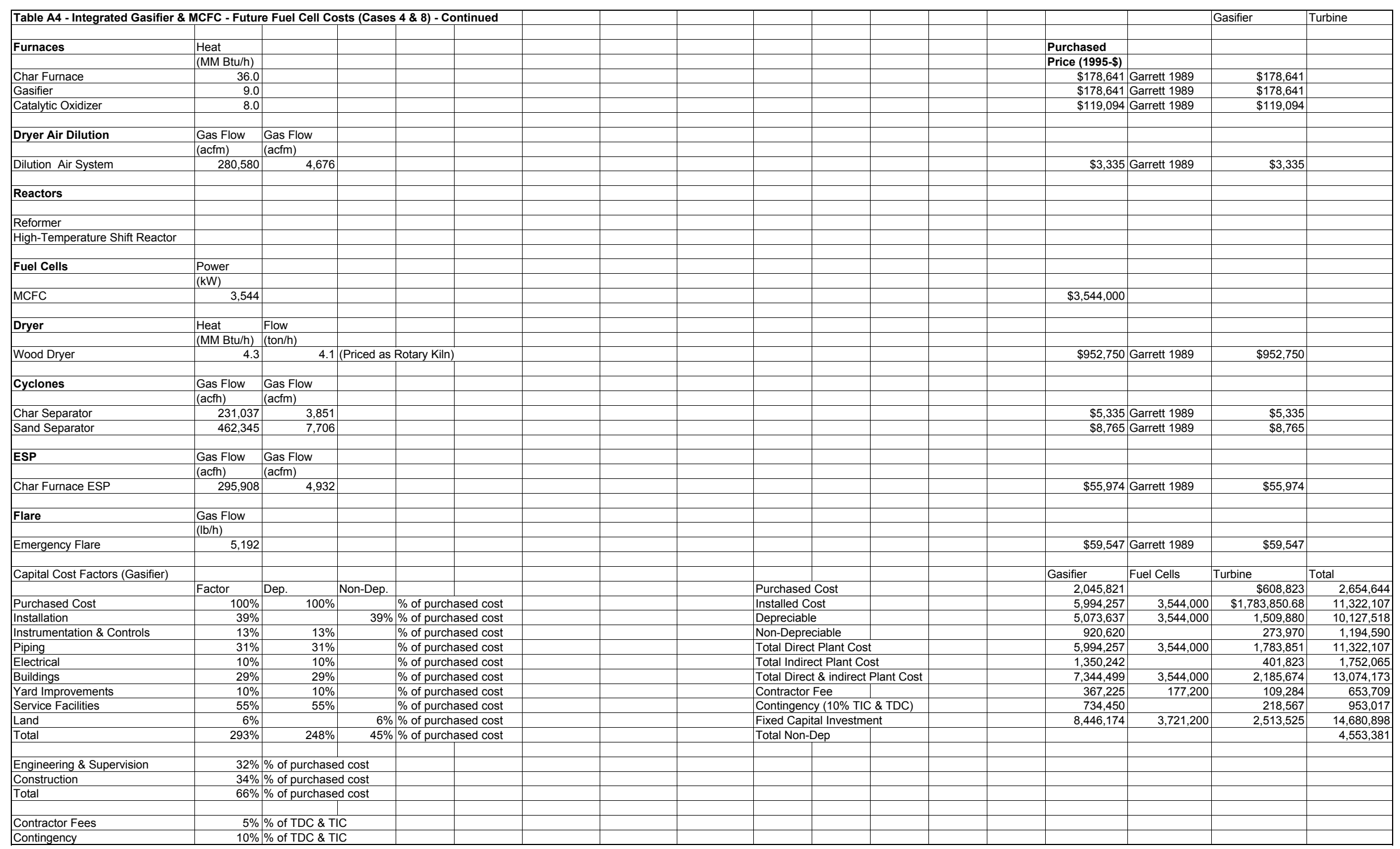




\begin{tabular}{|c|c|c|c|c|c|c|c|}
\hline \multicolumn{8}{|c|}{ Table A5 - Stand-Alone Gasifier w/PAFCs - Variable Operating Costs (Cases 1, 3, 5, \& 7) } \\
\hline & & & & & & & \\
\hline Operating Days/Year & 350 & days & & & & & \\
\hline \multirow[t]{2}{*}{ Fuel } & Flow-Wet & Flow-BD & Flow-Wet & Flow-BD & Cost & & Cost \\
\hline & $(\mathrm{lb} / \mathrm{h})$ & $(\mathrm{lb} / \mathrm{h})$ & $($ tpd) & (tpd) & $(\$ / B D$ ton $)$ & & $(\$ / y r)$ \\
\hline Wood & 4,585 & 4,081 & 55.02 & 48.9678 & $\$ 42.00$ & & $\$ 719,827$ \\
\hline Wood Residue & 4,585 & 4,081 & 55.02 & 48.9678 & $\$ 17.00$ & & $\$ 291,358$ \\
\hline \multirow[t]{2}{*}{ Water Use } & Flow & Flow & Cost & & & & Cost \\
\hline & $(\mathrm{lb} / \mathrm{h})$ & (gpm) & $(\$ / 1000$ gal $)$ & & & & $(\$ / y r)$ \\
\hline Process Water & 0 & 0 & $\$ 0.20$ & & & & $\$ 0$ \\
\hline Boiler Feed Water & 2,531 & 5 & $\$ 5.00$ & & & & $\$ 2,549$ \\
\hline \multirow[t]{2}{*}{ Cooling Water } & 130,135 & 260 & $\$ 0.20$ & & & & $\$ 131,071$ \\
\hline & & & & & & Total & $\$ 133,620$ \\
\hline \multirow[t]{2}{*}{ Power Production } & Electricity & Electricity & & & & & \\
\hline & $(\mathrm{kW})$ & $(\mathrm{kWh} / \mathrm{yr})$ & & & & & \\
\hline Net Output & 2,011 & \begin{tabular}{|r|}
$16,892,400$ \\
\end{tabular} & & & & & \\
\hline \multirow[t]{2}{*}{ Power Demand } & Electricity & & & & & & \\
\hline & $(\mathrm{kW})$ & & & & & & \\
\hline Char Furnace FD Fan & 119 & & & & & & \\
\hline Dilution Air FD Fan & 46 & & & & & & \\
\hline Gas Compressor & 13 & & & & & & \\
\hline Burner Air FD Fan & 15 & & & & & & \\
\hline Fuel Cell Air Compressor & 59 & & & & & & \\
\hline Cooler Cooling Pump & 5 & & & & & & \\
\hline Condenser Cooling Pump & 3 & & & & & & \\
\hline Total & 260 & & & & & & \\
\hline
\end{tabular}




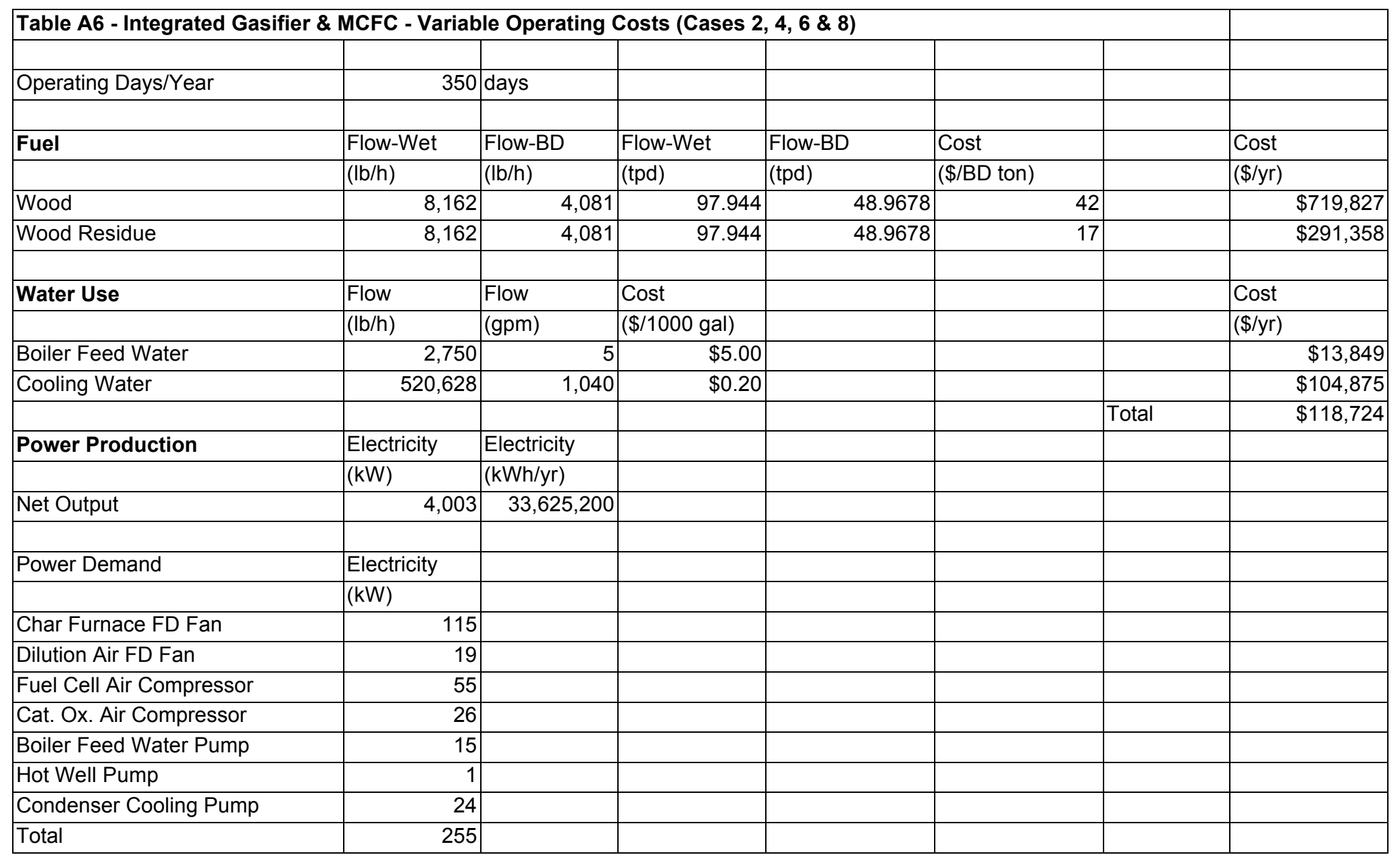




\begin{tabular}{|c|c|c|c|c|}
\hline \multicolumn{5}{|c|}{ Table A7 - Stand-Alone/PAFC, Current FC Costs, Wood (Case 1) } \\
\hline \multicolumn{5}{|c|}{ Discounted cash flow - rate of return } \\
\hline & & & & \\
\hline \multicolumn{2}{|l|}{ After Tax IRR = } & $15.00 \%$ & & \\
\hline Pre Tax IRR = & & $22.92 \%$ & & \\
\hline \multicolumn{5}{|c|}{ Construction Period $=2$ years } \\
\hline \multicolumn{2}{|c|}{ Assumed Sale Price } & $(\$ / k W h)=$ & & $\$ 0.472$ \\
\hline \multicolumn{3}{|c|}{ Electricity produced $(\mathrm{kWh} / \mathrm{yr})=$} & & $16,892,400$ \\
\hline \multicolumn{2}{|c|}{ Gross Income (MM $\$ / y r)$} & & & 7.98 \\
\hline \multicolumn{3}{|c|}{ Royalties $(0.5 \%$ of sales $)(\mathrm{MM} \$ / \mathrm{yr})=$} & & 0.04 \\
\hline \multicolumn{4}{|c|}{ Working Capital (30\% of annual sales) $(\mathrm{MM} \$)=$} & 2.39 \\
\hline \multicolumn{3}{|c|}{ Operating Costs $(\mathrm{MM} \$ / \mathrm{yr})=$} & \multirow{2}{*}{\multicolumn{2}{|c|}{ Operators }} \\
\hline & Labor & & & \\
\hline & & $\$ 28.75$ & per hour worked & 0.76 \\
\hline & & & supervisor cost (15\% of op. labor) & 0.11 \\
\hline & \multicolumn{3}{|c|}{ Maintenance and general expenses $(10 \%$ of $\mathrm{FCl})$} & 1.46 \\
\hline & \begin{tabular}{|l|l} 
Utilities & \\
\end{tabular} & & & 0.13 \\
\hline & \multicolumn{2}{|c|}{ Byproduct Credit } & & - \\
\hline & \begin{tabular}{|l|} 
Feed \\
\end{tabular} & & & 0.72 \\
\hline \multicolumn{3}{|c|}{ Non-depreciable Capital (\$MM) } & & 4.16 \\
\hline \multicolumn{3}{|c|}{ Depreciable Capital Costs (MM\$) = } & & 10.46 \\
\hline Tax Rate $=$ & & & & $37.00 \%$ \\
\hline Gasifier Dep. & 5.92 & (5 yrs) & & \\
\hline Fuel Cell Dep. & 4.54 & (15 yrs) & & \\
\hline Turbine Dep. & & (20 yrs) & & \\
\hline Total & 10.46 & & & \\
\hline Salvage & $10 \%$ & & & \\
\hline Salvage Value & 1.05 & & & \\
\hline
\end{tabular}




\begin{tabular}{|c|c|c|c|c|}
\hline \multicolumn{5}{|c|}{ Table A8 - Integrated/MCFC, Current FC Costs, Wood (Case 2) } \\
\hline \multicolumn{5}{|c|}{ Discounted cash flow - rate of return } \\
\hline & & & & \\
\hline \multicolumn{2}{|l|}{ After Tax IRR = } & $15.00 \%$ & & \\
\hline Pre Tax IRR = & & $21.15 \%$ & & \\
\hline & & & & \\
\hline \multicolumn{3}{|c|}{ Construction Period $=2$ years } & & \\
\hline \multicolumn{2}{|c|}{ Assumed Sale Price } & $(\$ / \mathrm{kWh})=$ & & $\$ 0.311$ \\
\hline \multicolumn{3}{|c|}{ Electricity produced $(\mathrm{kWh} / \mathrm{yr})=$} & & $33,625,200$ \\
\hline \multicolumn{2}{|c|}{ Gross Income (MM $\$ / y r)$} & & & 10.45 \\
\hline \multicolumn{3}{|c|}{ Royalties $(0.5 \%$ of sales $)(\mathrm{MM} \$ / \mathrm{yr})=$} & & 0.05 \\
\hline \multicolumn{4}{|c|}{ Working Capital (30\% of annual sales) $(\mathrm{MM} \$)=$} & 3.13 \\
\hline \multicolumn{3}{|c|}{ Operating Costs $(\mathrm{MM} \$ / \mathrm{yr})=$} & & 3.92 \\
\hline & Labor & 3 & Operators & \\
\hline & & $\$ 28.75$ & per hour worked & 0.76 \\
\hline & & & supervisor cost (15\% of op. labor) & 0.11 \\
\hline & \multicolumn{3}{|c|}{ Maintenance and general expenses $(10 \%$ of $\mathrm{FCl})$} & 2.21 \\
\hline & \begin{tabular}{|l|l} 
Utilities & \\
\end{tabular} & & & 0.12 \\
\hline & \multicolumn{2}{|l|}{ Byproduct Credit } & & - \\
\hline & \begin{tabular}{|l|l|} 
Feed & \\
\end{tabular} & & & 0.72 \\
\hline \multicolumn{3}{|c|}{ Non-depreciable Capital (\$MM) } & & 4.91 \\
\hline \multicolumn{3}{|c|}{ Depreciable Capital Costs $(\mathrm{MM} \$)=$} & & 17.22 \\
\hline Tax Rate $=$ & & & & $37.00 \%$ \\
\hline Gasifier Dep. & $5.07 \mid($ & (5 yrs) & & \\
\hline Fuel Cell Dep. & 10.63( & $(15 \mathrm{yrs})$ & & \\
\hline Turbine Dep. & $1.51 \mid($ & (20 yrs) & & \\
\hline Total & 17.22 & & & \\
\hline Salvage & $10 \%$ & & & \\
\hline Salvage Value & \begin{tabular}{l|}
1.72 \\
\end{tabular} & & & \\
\hline
\end{tabular}




\begin{tabular}{|c|c|c|c|c|}
\hline \multicolumn{5}{|c|}{ Table A9 - Stand-Alone/PAFC, Future FC Costs, Wood (Case 3) } \\
\hline \multicolumn{5}{|c|}{ Discounted cash flow - rate of return } \\
\hline & & & & \\
\hline \multicolumn{2}{|l|}{ After Tax IRR = } & $15.00 \%$ & & \\
\hline Pre Tax IRR = & & $23.77 \%$ & & \\
\hline \multicolumn{5}{|c|}{ Construction Period $=2$ years } \\
\hline \multirow{2}{*}{\multicolumn{2}{|c|}{ Assumed Sale Price }} & & & \\
\hline & & $(\$ / \mathrm{kWh})=$ & & $\$ 0.424$ \\
\hline \multicolumn{3}{|c|}{ Electricity produced $(\mathrm{kWh} / \mathrm{yr})=$} & & $16,892,400$ \\
\hline \multicolumn{2}{|c|}{ Gross Income (MM\$/yr) } & & & 7.17 \\
\hline \multicolumn{3}{|c|}{ Royalties $(0.5 \%$ of sales $)(\mathrm{MM} \$ / \mathrm{yr})=$} & & 0.04 \\
\hline \multicolumn{4}{|c|}{ Working Capital (30\% of annual sales) $(\mathrm{MM} \$)=$} & 2.15 \\
\hline \multicolumn{3}{|c|}{ Operating Costs $(\mathrm{MM} \$ / \mathrm{yr})=$} & \multicolumn{2}{|r|}{2.95} \\
\hline & Labor & & Operators & \\
\hline & & $\$ 28.75$ & per hour worked & 0.76 \\
\hline & & & supervisor cost (15\% of op. labor) & 0.11 \\
\hline & \multicolumn{3}{|c|}{ Maintenance and general expenses $(10 \%$ of $\mathrm{FCl})$} & 1.22 \\
\hline & \begin{tabular}{|l|l} 
Utilities &
\end{tabular} & & & 0.13 \\
\hline & \multicolumn{2}{|c|}{ Byproduct Credit } & & - \\
\hline & \begin{tabular}{|l|l} 
Feed &
\end{tabular} & & & 0.72 \\
\hline \multicolumn{3}{|c|}{ Non-depreciable Capital (\$MM) } & & 4.05 \\
\hline \multicolumn{3}{|c|}{ Depreciable Capital Costs $(\mathrm{MM} \$)=$} & & 8.19 \\
\hline Tax Rate $=$ & & & & $37.00 \%$ \\
\hline Gasifier Dep. & 5.92 & (5 yrs) & & \\
\hline Fuel Cell Dep. & 2.27( & $(15 \mathrm{yrs})$ & & \\
\hline Turbine Dep. & & (20 yrs) & & \\
\hline Total & 8.19 & & & \\
\hline Salvage & $10 \%$ & & & \\
\hline Salvage Value & 0.82 & & & \\
\hline
\end{tabular}




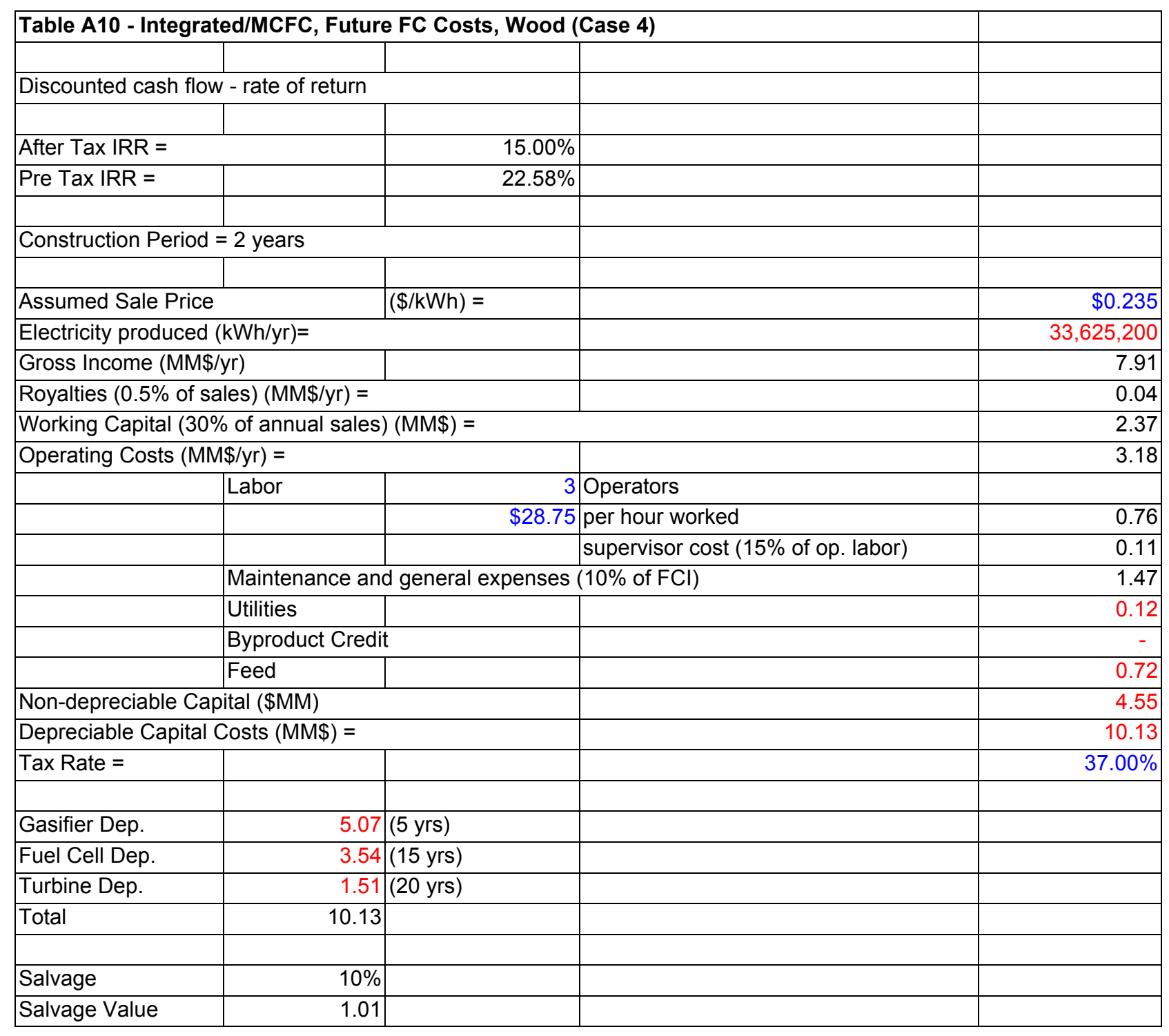




\begin{tabular}{|c|c|c|c|c|}
\hline \multicolumn{5}{|c|}{ Table A11 - Stand-Alone/PAFC, Current FC Costs, Residues (Case 5) } \\
\hline \multirow{2}{*}{\multicolumn{5}{|c|}{ Discounted cash flow - rate of return }} \\
\hline & & & & \\
\hline \multirow{2}{*}{\multicolumn{2}{|c|}{ After Tax IRR = }} & & & \\
\hline & & $15.00 \%$ & & \\
\hline Pre Tax IRR = & & $22.96 \%$ & & \\
\hline \multicolumn{5}{|c|}{ Construction Period $=2$ years } \\
\hline & & & & \\
\hline \multicolumn{2}{|c|}{ Assumed Sale Price } & $(\$ / k W h)=$ & & $\$ 0.446$ \\
\hline \multicolumn{3}{|c|}{ Electricity produced $(\mathrm{kWh} / \mathrm{yr})=$} & & $16,892,400$ \\
\hline \multicolumn{2}{|c|}{ Gross Income (MM $\$ / y r)$} & & & 7.53 \\
\hline \multicolumn{3}{|c|}{ Royalties $(0.5 \%$ of sales $)(\mathrm{MM} \$ / \mathrm{yr})=$} & & 0.04 \\
\hline \multicolumn{4}{|c|}{ Working Capital (30\% of annual sales) $(\mathrm{MM} \$)=$} & 2.26 \\
\hline \multicolumn{3}{|c|}{ Operating Costs $(\mathrm{MM} \$ / \mathrm{yr})=$} & & 2.76 \\
\hline & Labor & 3 & Operators & \\
\hline & & $\$ 28.75$ & per hour worked & 0.76 \\
\hline & & & supervisor cost (15\% of op. labor) & 0.11 \\
\hline & \multicolumn{3}{|c|}{ Maintenance and general expenses $(10 \%$ of $\mathrm{FCl})$} & 1.46 \\
\hline & \begin{tabular}{|l|l} 
Utilities & \\
\end{tabular} & & & 0.13 \\
\hline & \multicolumn{2}{|l|}{ Byproduct Credit } & & - \\
\hline & Feed & & & 0.29 \\
\hline \multicolumn{3}{|c|}{ Non-depreciable Capital (\$MM) } & & 4.16 \\
\hline \multicolumn{3}{|c|}{ Depreciable Capital Costs $(\mathrm{MM} \$)=$} & & 10.46 \\
\hline Tax Rate $=$ & & & & $37.00 \%$ \\
\hline Gasifier Dep. & 5.92 & (5 yrs) & & \\
\hline Fuel Cell Dep. & 4.54 & (15 yrs) & & \\
\hline Turbine Dep. & & (20 yrs) & & \\
\hline Total & 10.46 & & & \\
\hline Salvage & $10 \%$ & & & \\
\hline Salvage Value & 1.05 & & & \\
\hline
\end{tabular}




\begin{tabular}{|c|c|c|c|c|}
\hline \multicolumn{5}{|c|}{ Table A12 - Integrated/MCFC, Current FC Costs, Residues (Case 6) } \\
\hline \multicolumn{5}{|c|}{ Discounted cash flow - rate of return } \\
\hline & & & & \\
\hline \multicolumn{2}{|l|}{ After Tax IRR = } & $15.00 \%$ & & \\
\hline Pre Tax IRR = & & $21.17 \%$ & & \\
\hline \multicolumn{3}{|c|}{ Construction Period $=2$ years } & & \\
\hline \multirow{2}{*}{\multicolumn{2}{|c|}{ Assumed Sale Price }} & & & \\
\hline & & $(\$ / \mathrm{kWh})=$ & & $\$ 0.297$ \\
\hline \multicolumn{3}{|c|}{ Electricity produced $(\mathrm{kWh} / \mathrm{yr})=$} & & $33,625,200$ \\
\hline \multicolumn{2}{|c|}{ Gross Income (MM\$/yr) } & & & 10.00 \\
\hline \multicolumn{3}{|c|}{ Royalties $(0.5 \%$ of sales $)(\mathrm{MM} \$ / \mathrm{yr})=$} & & 0.05 \\
\hline \multicolumn{4}{|c|}{ Working Capital (30\% of annual sales) $(\mathrm{MM} \$)=$} & 3.00 \\
\hline \multicolumn{3}{|c|}{ Operating Costs $(\mathrm{MM} \$ / \mathrm{yr})=$} & \multirow{2}{*}{\multicolumn{2}{|c|}{ Operators }} \\
\hline & Labor & 3 & & \\
\hline & & $\$ 28.75$ & per hour worked & 0.76 \\
\hline & & & supervisor cost (15\% of op. labor) & 0.11 \\
\hline & \multicolumn{3}{|c|}{ Maintenance and general expenses $(10 \%$ of $\mathrm{FCl})$} & 2.21 \\
\hline & \begin{tabular}{|l|l} 
Utilities & \\
\end{tabular} & & & 0.12 \\
\hline & \multicolumn{2}{|l|}{ Byproduct Credit } & & - \\
\hline & \begin{tabular}{|l|l|} 
Feed & \\
\end{tabular} & & & 0.29 \\
\hline \multicolumn{3}{|c|}{ Non-depreciable Capital (\$MM) } & & 4.91 \\
\hline \multicolumn{3}{|c|}{ Depreciable Capital Costs $(\mathrm{MM} \$)=$} & & 17.22 \\
\hline Tax Rate $=$ & & & & $37.00 \%$ \\
\hline Gasifier Dep. & $5.07 \mid($ & (5 yrs) & & \\
\hline Fuel Cell Dep. & 10.63( & $(15 \mathrm{yrs})$ & & \\
\hline Turbine Dep. & $1.51 \mid($ & (20 yrs) & & \\
\hline Total & 17.22 & & & \\
\hline Salvage & $10 \%$ & & & \\
\hline Salvage Value & 1.72 & & & \\
\hline
\end{tabular}




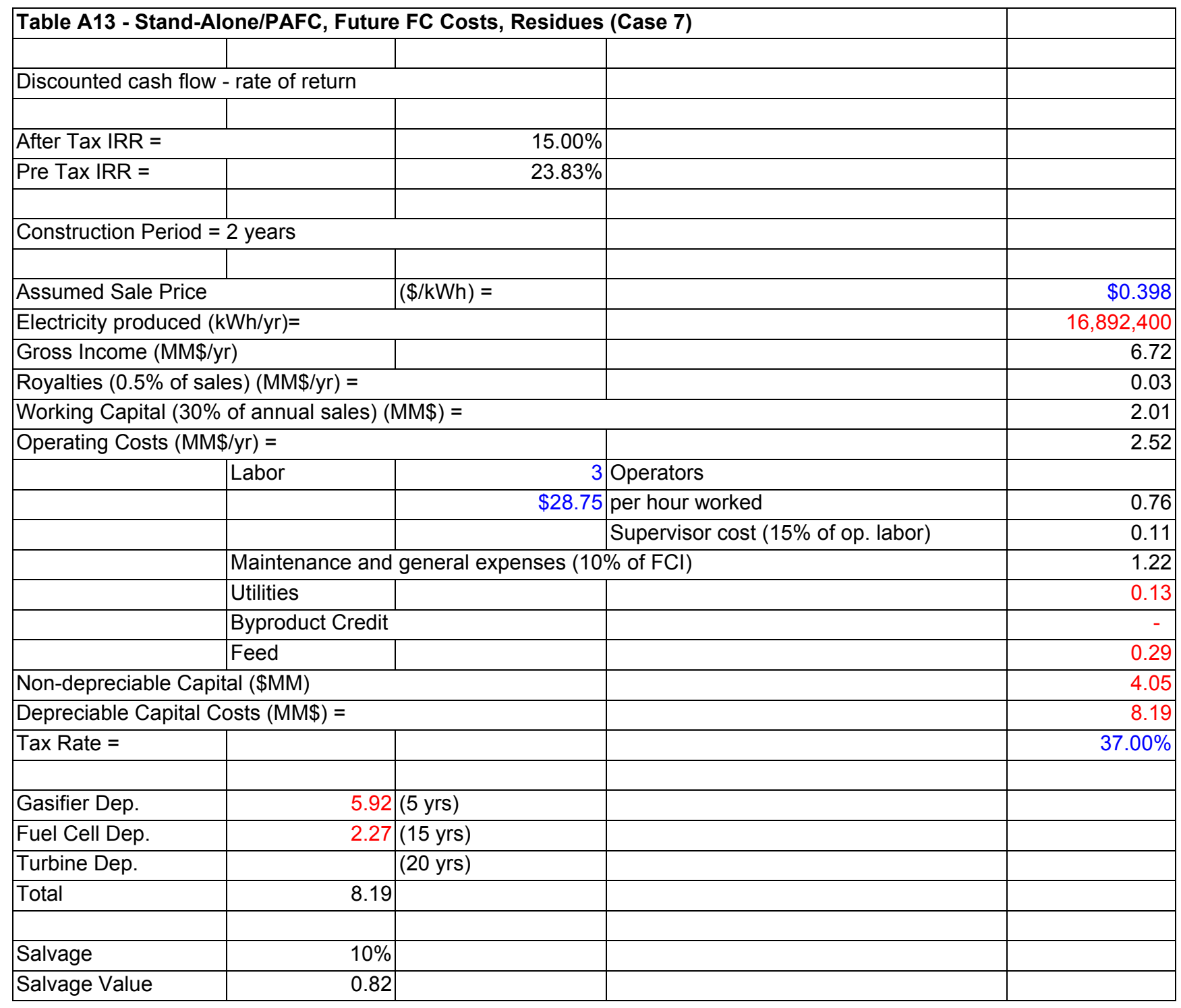




\begin{tabular}{|c|c|c|c|c|}
\hline \multicolumn{5}{|c|}{ Table A14 - Integrated/MCFC, Future FC Costs, Residues (Case 8) } \\
\hline \multicolumn{5}{|c|}{ Discounted cash flow - rate of return } \\
\hline & & & & \\
\hline \multicolumn{2}{|l|}{ After Tax IRR = } & $15.00 \%$ & & \\
\hline Pre Tax IRR = & & $22.62 \%$ & & \\
\hline \multicolumn{3}{|c|}{ Construction Period $=2$ years } & & \\
\hline \multicolumn{2}{|c|}{ Assumed Sale Price } & $(\$ / k W h)=$ & & $\$ 0.222$ \\
\hline \multicolumn{3}{|c|}{ Electricity produced $(\mathrm{kWh} / \mathrm{yr})=$} & & $33,625,200$ \\
\hline \multicolumn{2}{|c|}{ Gross Income (MM $\$ / y r)$} & & & 7.46 \\
\hline \multicolumn{3}{|c|}{ Royalties $(0.5 \%$ of sales $)(\mathrm{MM} \$ / \mathrm{yr})=$} & & 0.04 \\
\hline \multicolumn{4}{|c|}{ Working Capital (30\% of annual sales) $(\mathrm{MM} \$)=$} & 2.24 \\
\hline \multicolumn{3}{|c|}{ Operating Costs $(\mathrm{MM} \$ / \mathrm{yr})=$} & \multirow{2}{*}{\multicolumn{2}{|c|}{ Operators }} \\
\hline & Labor & 3 & & \\
\hline & & $\$ 28.75$ & per hour worked & 0.76 \\
\hline & & & supervisor cost (15\% of op. labor) & 0.11 \\
\hline & \multicolumn{3}{|c|}{ Maintenance and general expenses (10\% of $\mathrm{FCl})$} & 1.47 \\
\hline & \begin{tabular}{|l|l} 
Utilities & \\
\end{tabular} & & & 0.12 \\
\hline & \multicolumn{2}{|l|}{ Byproduct Credit } & & - \\
\hline & \begin{tabular}{|l|l|} 
Feed &
\end{tabular} & & & 0.29 \\
\hline \multicolumn{3}{|c|}{ Non-depreciable Capital (\$MM) } & & 4.55 \\
\hline \multicolumn{3}{|c|}{ Depreciable Capital Costs (MM\$) = } & & 10.13 \\
\hline Tax Rate $=$ & & & & $37.00 \%$ \\
\hline Gasifier Dep. & 5.07 & (5 yrs) & & \\
\hline Fuel Cell Dep. & 3.54 & (15 yrs) & & \\
\hline Turbine Dep. & 1.51 & (20 yrs) & & \\
\hline Total & 10.13 & & & \\
\hline Salvage & $10 \%$ & & & \\
\hline Salvage Value & 1.01 & & & \\
\hline
\end{tabular}




\section{APPENDIX B - STREAM TABLES}

Appendix B contains the stream tables for both the stand-alone and integrated biomass gasification/fuel cell designs. Flowrates are provided in both English and SI units, and the molar compositions are also given for all gas streams.

Figures B1, B2 and B3 are for the stand-alone plant design. The stream data for these flowsheets can be found in Tables B1 and B2. Figures B4, B5 and B6 are for the integrated case. The corresponding stream data can be found in Tables B3 and B4.

Below is a list of the figures and tables in Appendix B, with a brief description of each one.

Figure B1 - Gasifier flowsheet for stand-alone design.

Figure B2 - Gas processing section for stand-alone design.

Figure B3 - PAFC flowsheet for stand-alone design.

Figure B4 - Gasifier flowsheet for integrated design.

Figure B5 - MCFC flowsheet for integrated design.

Figure B6 - Steam cycle for integrated design.

Table B1 - Stream compositions and mass flowrates in lb/h.

Table B2 - Mass flowrates in $\mathrm{kg} / \mathrm{h}$.

Table B3 - Stream compositions and mass flowrates in $\mathrm{lb} / \mathrm{h}$.

Table B4 - Mass flowrates in $\mathrm{kg} / \mathrm{h}$. 
Figure B1 - Stand-Alone Gasifier Flowsheet

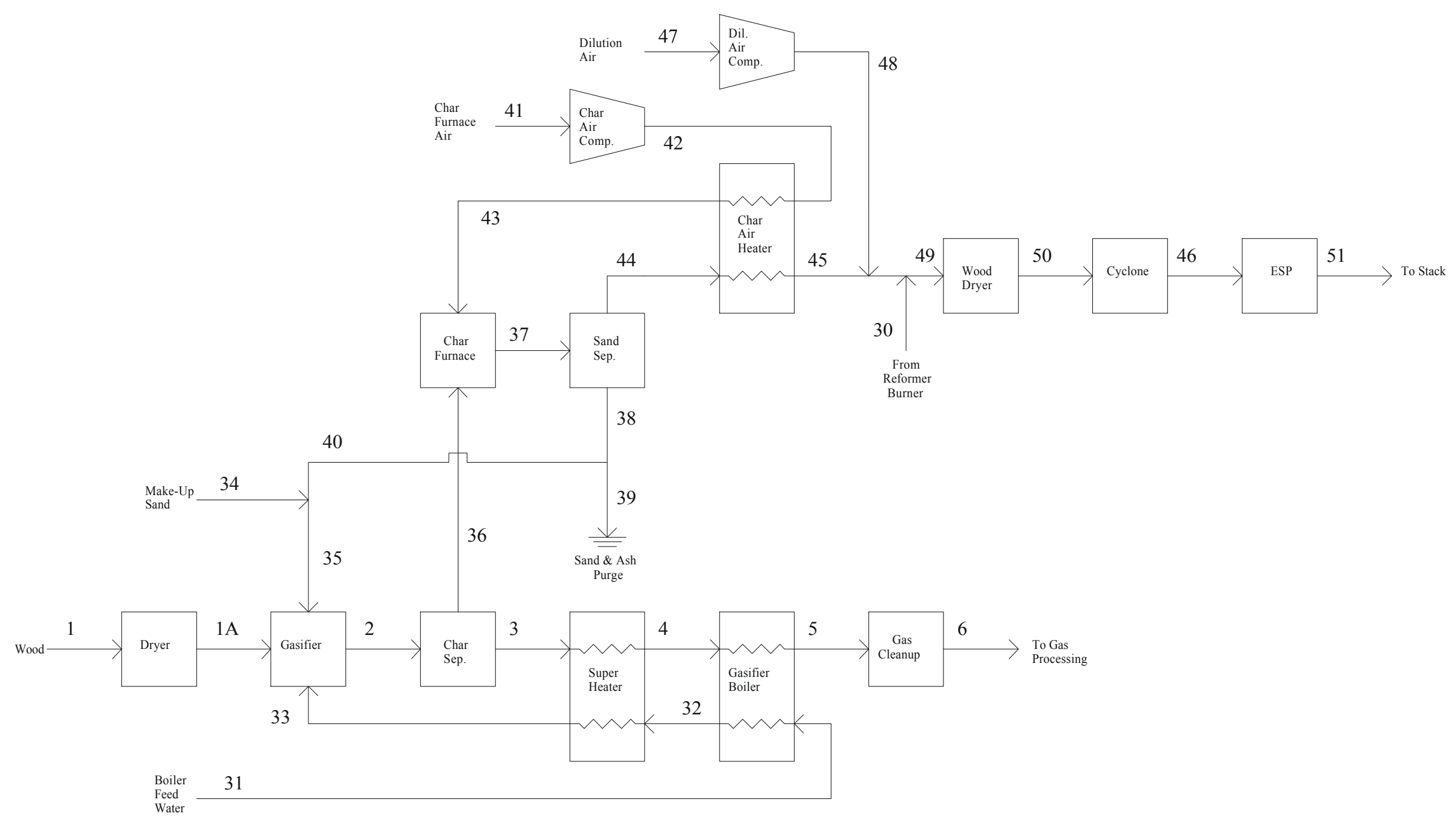


Figure B2 - Stand-Alone Gas Processing Flowsheet

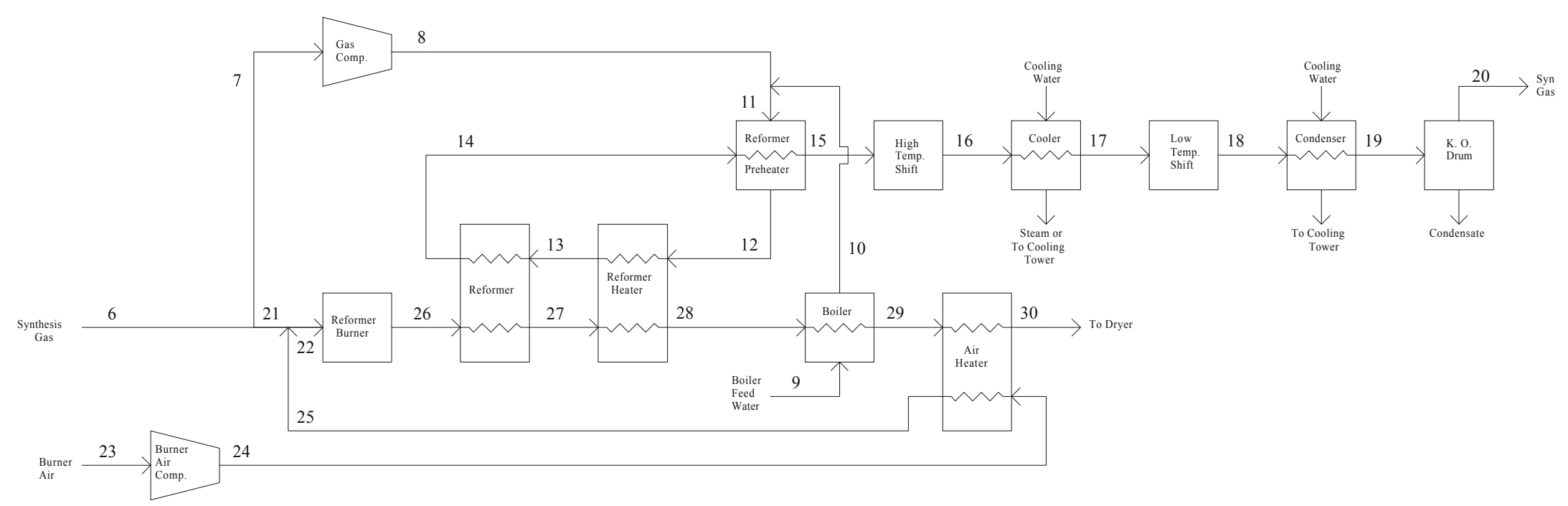


Figure B3 - Stand-Alone PAFC Flowsheet

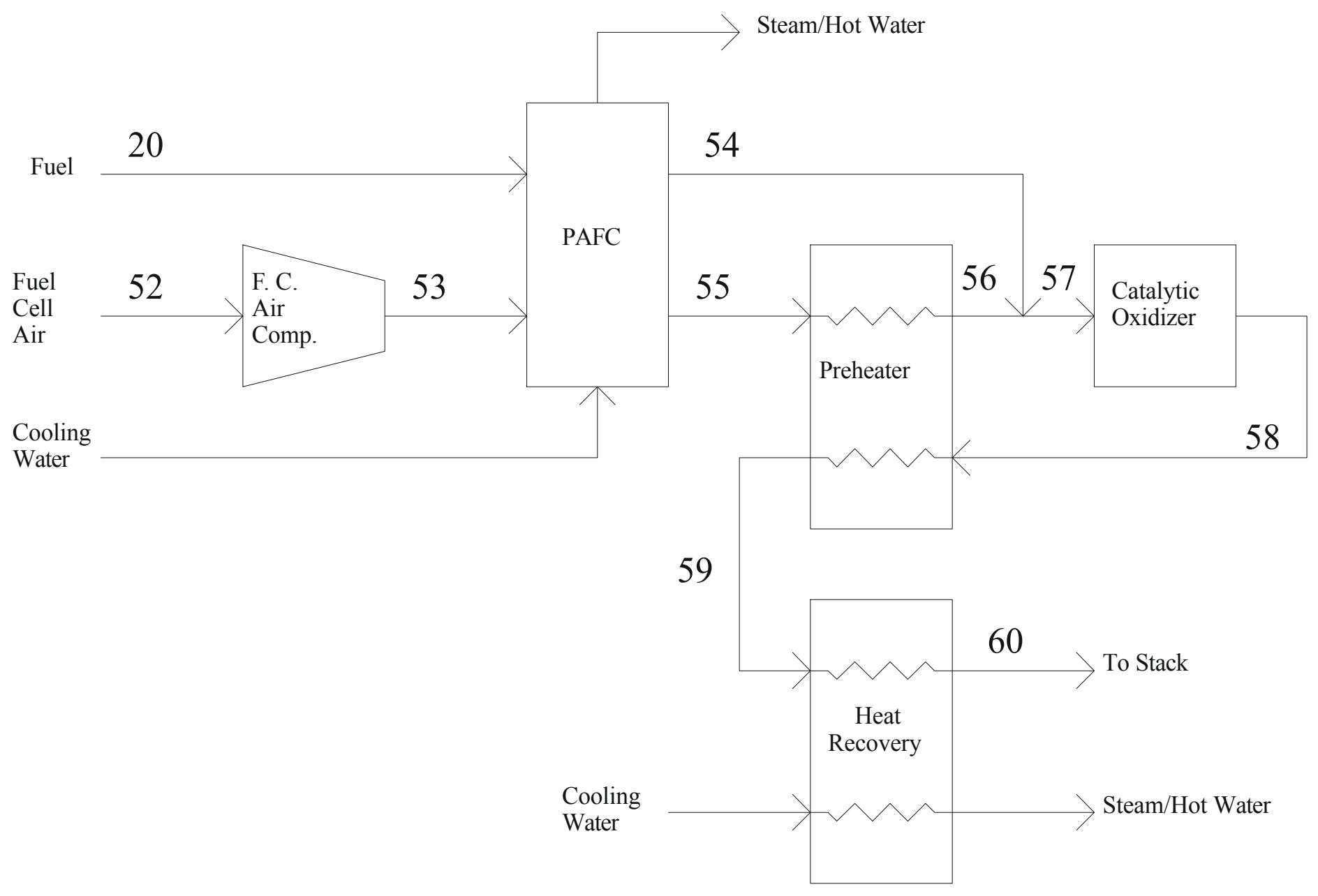




\section{Table B1 - Stream Table for Stand-Alone Gasifier/PAFC Design Units)}

\begin{tabular}{|c|c|c|c|c|c|c|c|c|c|c|}
\hline Steam \# & 1 & $1 \mathrm{~A}$ & 2 & 3 & 4 & 5 & 6 & 7 & 8 & 9 \\
\hline Temp. $\left({ }^{\circ} \mathrm{F}\right)$ & 59 & 80 & 1482 & 1482 & 1240 & 380 & 380 & 404 & 404 & 59 \\
\hline Pressure (psia) & 14.7 & 14.7 & 25 & 24.5 & 23.9 & 23.4 & 22.7 & 24.6 & 24.6 & 25 \\
\hline \multicolumn{11}{|l|}{$\mathrm{O} 2(\mathrm{lb} / \mathrm{h})$} \\
\hline \multicolumn{11}{|l|}{ N2 (lb/h) } \\
\hline $\mathrm{H} 2(\mathrm{lb} / \mathrm{h})$ & & & 100 & 100 & 100 & 100 & 100 & 100 & 100 & \\
\hline $\mathrm{CO}(\mathrm{lb} / \mathrm{h})$ & & & 1,428 & 1,428 & 1,428 & 1,428 & 1,428 & 1,428 & 1,428 & \\
\hline CO2 (lb/h) & & & 702 & 702 & 702 & 702 & 702 & 702 & 702 & \\
\hline $\mathrm{H} 2 \mathrm{O}(\mathrm{lb} / \mathrm{h})$ & 4,080 & 504 & 2,339 & 2,339 & 2,339 & 2,339 & 2,339 & 2,339 & 2,339 & 706 \\
\hline CH4 (lb/h) & & & 299 & 299 & 299 & 299 & 299 & 299 & 299 & \\
\hline H2S (lb/h) & & & 3.58 & 3.58 & 3.58 & 3.58 & 3.58 & 3.58 & 3.58 & \\
\hline \multicolumn{11}{|l|}{ SO2 (lb/h) } \\
\hline $\mathrm{NH3}(\mathrm{lb} / \mathrm{h})$ & & & 7.88 & 7.88 & 7.88 & 7.88 & 7.88 & 7.88 & 7.88 & \\
\hline \multicolumn{11}{|l|}{$\cos (\mathrm{lb} / \mathrm{h})$} \\
\hline Tar - C10H8 (lb/h) & & & 66.2 & 66.2 & 66.2 & 66.2 & 66.2 & 66.2 & 66.2 & \\
\hline $\mathrm{C} 2 \mathrm{H} 2(\mathrm{lb} / \mathrm{h})$ & & & 10.1 & 10.1 & 10.1 & 10.1 & 10.1 & 10.1 & 10.1 & \\
\hline $\mathrm{C} 2 \mathrm{H} 4$ (lb/h) & & & 152 & 152 & 152 & 152 & 152 & 152 & 152 & \\
\hline $\mathrm{C} 2 \mathrm{H} 6$ (lb/h) & & & 19.2 & 19.2 & 19.2 & 19.2 & 19.2 & 19.2 & 19.2 & \\
\hline Sand (lb/h) & & & 82,807 & & & & & & & \\
\hline Char (Ib/h) & & & 3,123 & & & & & & & \\
\hline Wood (Ib/h) & 4,080 & 4,080 & & & & & & & & \\
\hline \multicolumn{11}{|l|}{ Ash $(\mathrm{lb} / \mathrm{h})$} \\
\hline Total $(\mathrm{Ib} / \mathrm{h})$ & 8,160 & 4,584 & 91,057 & 5,127 & 5,127 & 5,127 & 5,127 & 5,127 & 5,127 & 706 \\
\hline \multicolumn{11}{|l|}{$\mathrm{O} 2$ (mol. frac.) } \\
\hline \multicolumn{11}{|l|}{ N2 (mol. frac.) } \\
\hline $\mathrm{H} 2$ (mol. frac.) & & & 0.183 & 0.183 & 0.183 & 0.183 & 0.183 & 0.183 & 0.183 & \\
\hline $\mathrm{CO}$ (mol. frac.) & & & 0.187 & 0.187 & 0.187 & 0.187 & 0.187 & 0.187 & 0.187 & \\
\hline $\mathrm{CO} 2$ (mol. frac.) & & & 0.059 & 0.059 & 0.059 & 0.059 & 0.059 & 0.059 & 0.059 & \\
\hline $\mathrm{H} 2 \mathrm{O}$ (mol. frac.) & & & 0.476 & 0.476 & 0.476 & 0.476 & 0.476 & 0.476 & 0.476 & \\
\hline $\mathrm{CH} 4$ (mol. frac.) & & & 0.068 & 0.068 & 0.068 & 0.068 & 0.068 & 0.068 & 0.068 & \\
\hline H2S (mol. frac.) & & & $3.85 E-4$ & $3.85 E-4$ & $3.85 E-4$ & $3.85 E-4$ & $3.85 E-4$ & $3.85 E-4$ & $3.85 E-4$ & \\
\hline \multicolumn{11}{|l|}{ SO2 (mol. frac.) } \\
\hline NH3 (mol. frac.) & & & 0.002 & 0.002 & 0.002 & 0.002 & 0.002 & 0.002 & 0.002 & \\
\hline \multicolumn{11}{|l|}{ COS (mol. frac.) } \\
\hline Tar - C10H8 (mol. frac.) & & & 0.002 & 0.002 & 0.002 & 0.002 & 0.002 & 0.002 & 0.002 & \\
\hline $\mathrm{C} 2 \mathrm{H} 2$ (mol. frac.) & & & 0.001 & 0.001 & 0.001 & 0.001 & 0.001 & 0.001 & 0.001 & \\
\hline $\mathrm{C} 2 \mathrm{H} 4$ (mol. frac.) & & & 0.020 & 0.020 & 0.020 & 0.020 & 0.020 & 0.020 & 0.020 & \\
\hline C2H6 (mol. frac.) & & & 0.002 & 0.002 & 0.002 & 0.002 & 0.002 & 0.002 & 0.002 & \\
\hline
\end{tabular}


Table B1 - Stream Table for Stand-Alone Gasifier/PAFC Design (English Units)

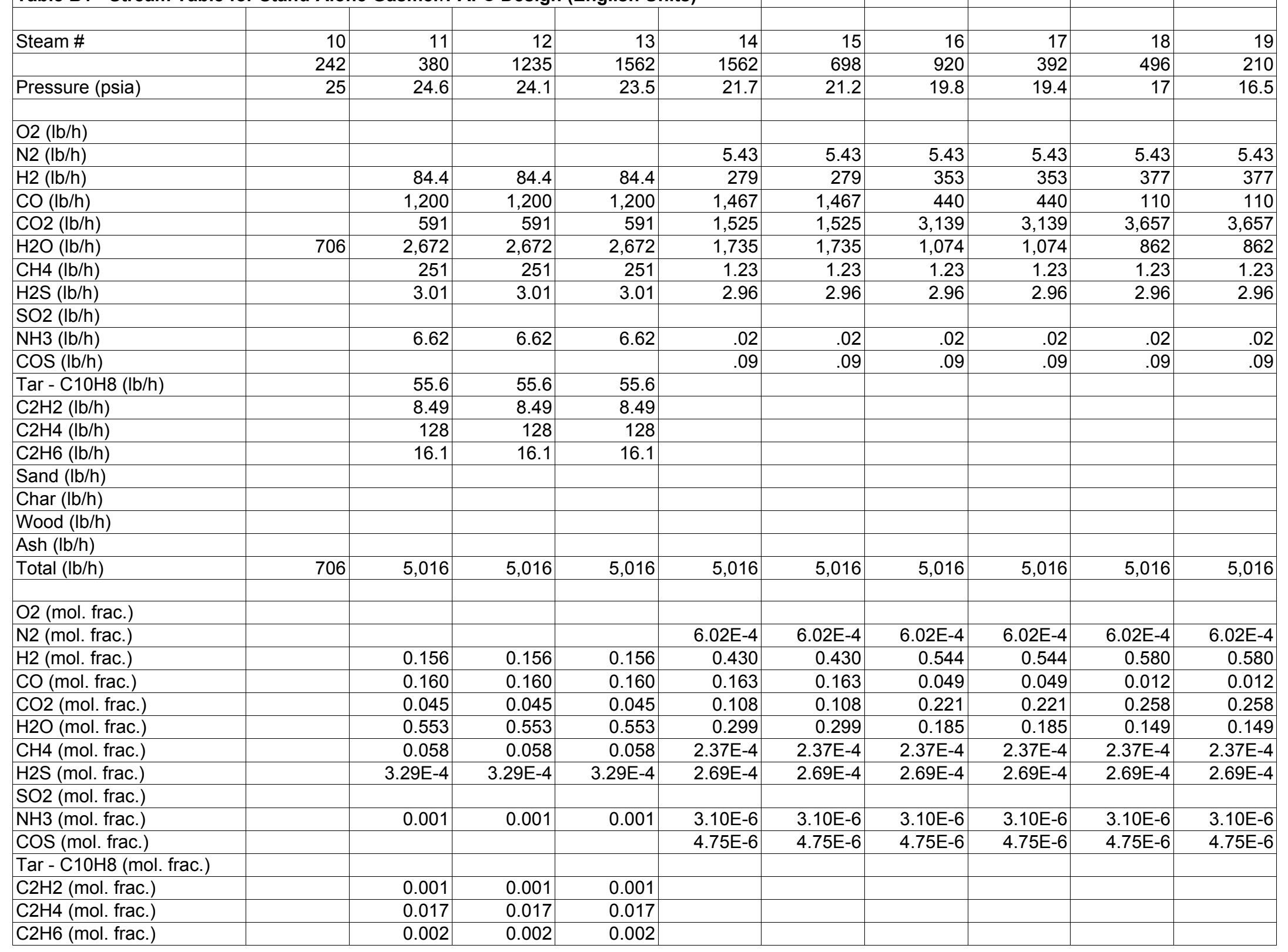


Table B1 - Stream Table for Stand-Alone Gasifier/PAFC Design (English Units) - Continued

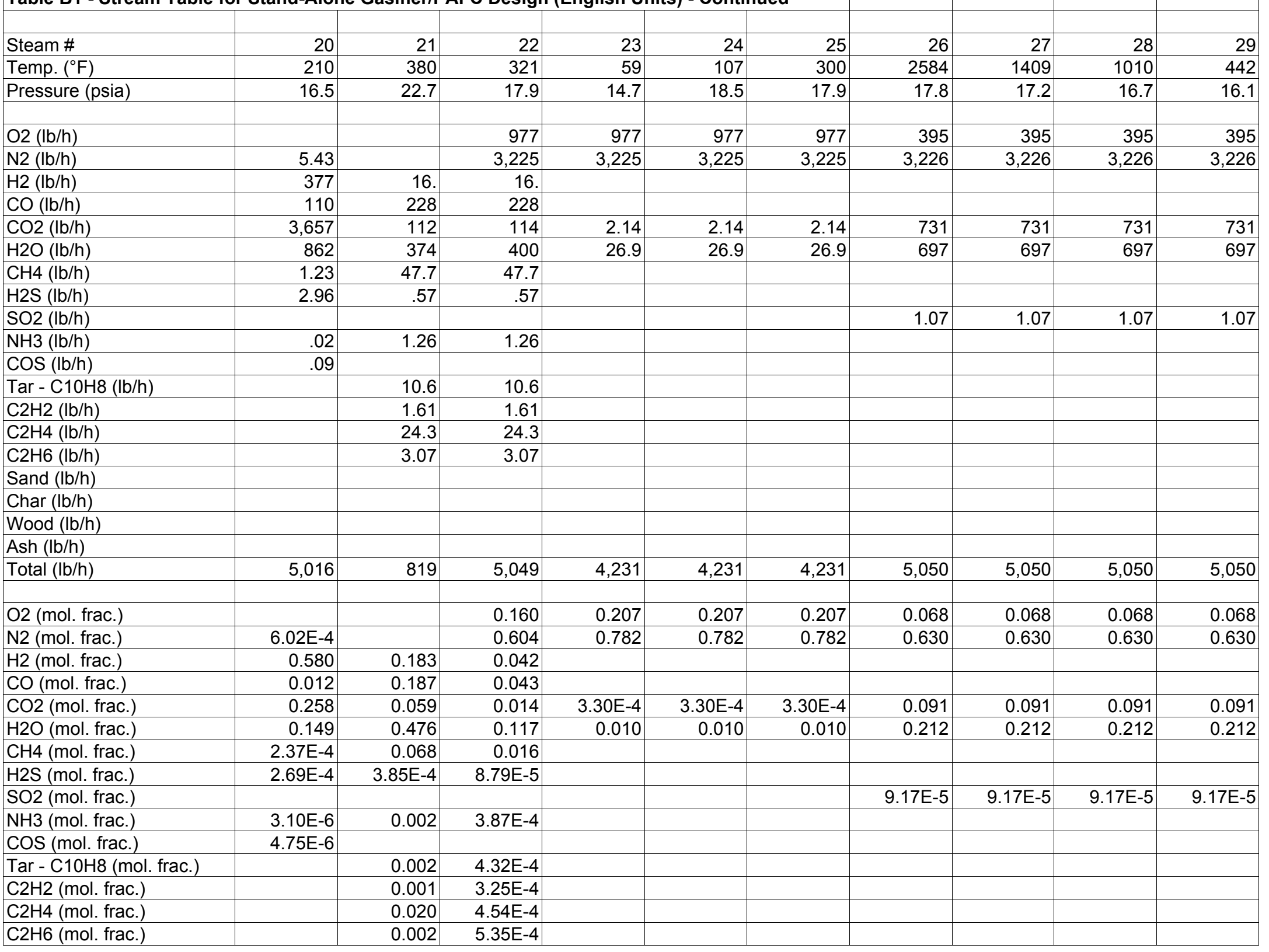


Table B1 - Stream Table for Stand-Alone Gasifier/PAFC Design (English Units) - Continued

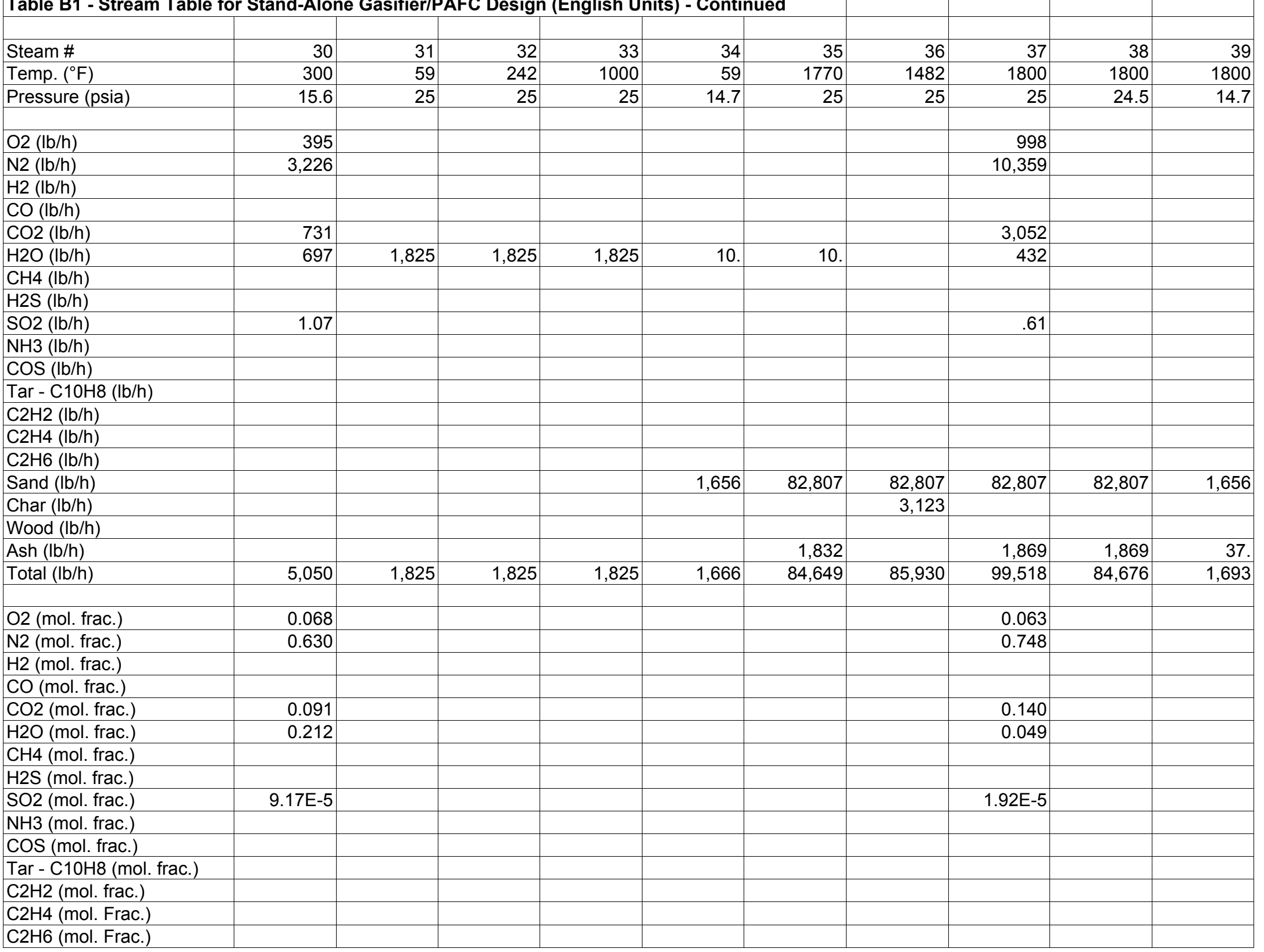


Table B1 - Stream Table for Stand-Alone Gasifier/PAFC Design (English Units) - Continued

\begin{tabular}{|c|c|c|c|c|c|c|c|c|c|c|}
\hline Steam \# & 40 & 41 & 42 & 43 & 44 & 45 & 46 & 47 & 48 & 49 \\
\hline Temp. $\left({ }^{\circ} \mathrm{F}\right)$ & 1800 & 59 & 182 & 325 & 1800 & 1693 & 220 & 59 & 71 & 450 \\
\hline \multirow[t]{2}{*}{ Pressure (psia) } & 24.5 & 14.7 & 25.6 & 25 & 24.5 & 23.9 & 14.7 & 14.7 & 15.6 & 15.6 \\
\hline & & & & & & & & & & \\
\hline $\mathrm{O} 2$ (lb/h) & & 3,137 & 3,137 & 3,137 & 998 & 998 & 13,623 & 12,230 & 12,230 & 13,623 \\
\hline N2 (lb/h) & & 10,359 & 10,359 & 10,359 & 10,359 & 10,359 & 53,978 & 40,392 & 40,392 & 53,978 \\
\hline \multicolumn{11}{|l|}{$\mathrm{H} 2$ (lb/h) } \\
\hline \multicolumn{11}{|l|}{$\mathrm{CO}(\mathrm{lb} / \mathrm{h})$} \\
\hline $\mathrm{CO} 2(\mathrm{lb} / \mathrm{h})$ & & 6.87 & 6.87 & 6.87 & 3,052 & 3,052 & 3,810 & 26.8 & 26.8 & 3,810 \\
\hline $\mathrm{H} 2 \mathrm{O}(\mathrm{lb} / \mathrm{h})$ & & 86.4 & 86.4 & 86.4 & 432 & 432 & 5,042 & 337 & 337 & 1,466 \\
\hline \multicolumn{11}{|l|}{$\mathrm{CH} 4(\mathrm{lb} / \mathrm{h})$} \\
\hline \multicolumn{11}{|l|}{$\mathrm{H} 2 \mathrm{~S}(\mathrm{lb} / \mathrm{h})$} \\
\hline $\mathrm{SO} 2(\mathrm{lb} / \mathrm{h})$ & & & & & .61 & .61 & 1.68 & & & 1.68 \\
\hline \multicolumn{11}{|l|}{$\mathrm{NH3}(\mathrm{lb} / \mathrm{h})$} \\
\hline \multicolumn{11}{|l|}{$\cos (\mathrm{lb} / \mathrm{h})$} \\
\hline \multicolumn{11}{|l|}{ Tar - C10H8 (lb/h) } \\
\hline \multicolumn{11}{|l|}{$\mathrm{C} 2 \mathrm{H} 2(\mathrm{lb} / \mathrm{h})$} \\
\hline \multicolumn{11}{|l|}{ C2H4 (lb/h) } \\
\hline \multicolumn{11}{|l|}{$\mathrm{C} 2 \mathrm{H} 6(\mathrm{lb} / \mathrm{h})$} \\
\hline Sand $(\mathrm{lb} / \mathrm{h})$ & 81,151 & & & & & & & & & \\
\hline \multicolumn{11}{|l|}{ Char (lb/h) } \\
\hline \multicolumn{11}{|l|}{ Wood (lb/h) } \\
\hline Ash $(\mathrm{lb} / \mathrm{h})$ & 1,832 & & & & & & & & & \\
\hline Total (lb/h) & 82,983 & 13,589 & 13,589 & 13,589 & 14,842 & 14,842 & 76,455 & 52,986 & 52,986 & 72,879 \\
\hline & & & & & & & & & & \\
\hline $\mathrm{O} 2$ (mol. frac.) & & 0.207 & 0.207 & 0.207 & 0.063 & 0.063 & 0.157 & 0.207 & 0.207 & 0.169 \\
\hline N2 (mol. frac.) & & 0.782 & 0.782 & 0.782 & 0.748 & 0.748 & 0.709 & 0.782 & 0.782 & 0.764 \\
\hline \multicolumn{11}{|l|}{$\mathrm{H} 2$ (mol. frac.) } \\
\hline \multicolumn{11}{|l|}{$\mathrm{CO}$ (mol. frac.) } \\
\hline CO2 (mol. frac.) & & $3.30 \mathrm{E}-4$ & $3.30 \mathrm{E}-4$ & $3.30 \mathrm{E}-4$ & 0.140 & 0.140 & 0.032 & $3.30 \mathrm{E}-4$ & $3.30 \mathrm{E}-4$ & 0.034 \\
\hline $\mathrm{H} 2 \mathrm{O}$ (mol. frac.) & & 0.010 & 0.010 & 0.010 & 0.049 & 0.049 & 0.103 & 0.010 & 0.010 & 0.032 \\
\hline \multicolumn{11}{|l|}{$\mathrm{CH} 4$ (mol. frac.) } \\
\hline \multicolumn{11}{|l|}{ H2S (mol. frac.) } \\
\hline SO2 (mol. frac.) & & & & & $1.92 \mathrm{E}-5$ & $1.92 \mathrm{E}-5$ & 9.67E-6 & & & $1.04 \mathrm{E}-5$ \\
\hline \multicolumn{11}{|l|}{$\mathrm{NH} 3$ (mol. frac.) } \\
\hline \multicolumn{11}{|c|}{$\cos$ (mol. frac.) } \\
\hline \multicolumn{11}{|c|}{ Tar - C10H8 (mol. frac.) } \\
\hline \multicolumn{11}{|c|}{$\mathrm{C} 2 \mathrm{H} 2$ (mol. frac.) } \\
\hline \multicolumn{11}{|l|}{$\mathrm{C} 2 \mathrm{H} 4$ (mol. frac.) } \\
\hline C2H6 (mol. frac.) & & & & & & & & & & \\
\hline
\end{tabular}




\section{Table B1 - Stream Table for Stand-Alone Gasifier/PAFC Design (English Units) - Continued}

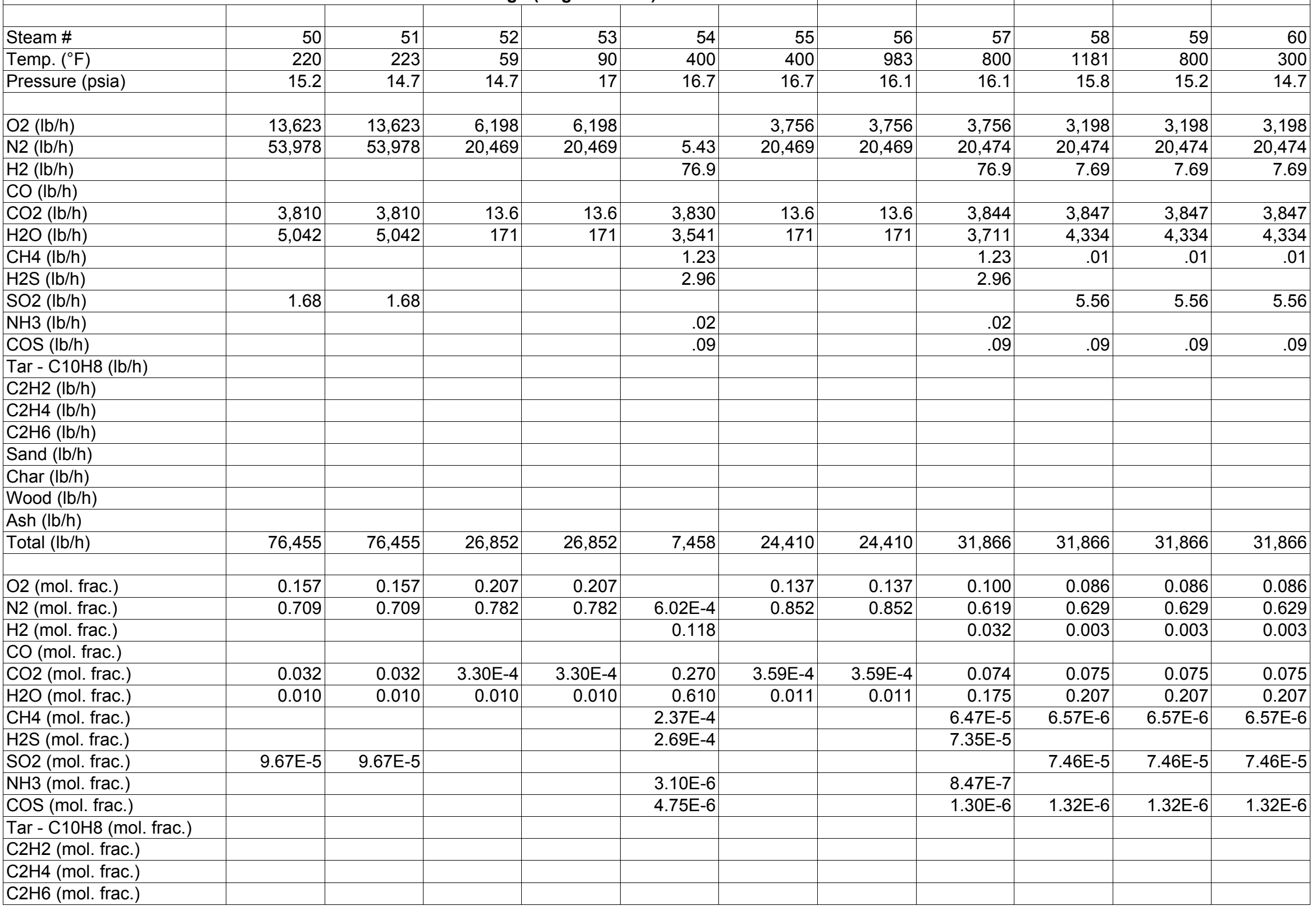




\begin{tabular}{|c|c|c|c|c|c|c|c|c|c|c|}
\hline \multicolumn{11}{|c|}{ Table B2 - Stream Table for Stand-Alone Gasifier/PAFC Design (SI Units) } \\
\hline & & & & & & & & & & \\
\hline Steam \# & 1 & $1 \mathrm{~A}$ & 2 & 3 & 4 & 5 & 6 & 7 & 8 & 9 \\
\hline Temp. (K) & 288 & 300 & 1,079 & 1,079 & 944 & 467 & 467 & 480 & 480 & 288 \\
\hline \multicolumn{11}{|l|}{$\mathrm{O} 2(\mathrm{~kg} / \mathrm{h})$} \\
\hline \multicolumn{11}{|l|}{$\mathrm{N} 2(\mathrm{~kg} / \mathrm{h})$} \\
\hline $\mathrm{CO}(\mathrm{kg} / \mathrm{h})$ & & & 648 & 648 & 648 & 648 & 648 & 648 & 648 & \\
\hline $\mathrm{CO} 2(\mathrm{~kg} / \mathrm{h})$ & & & 318 & 318 & 318 & 318 & 318 & 318 & 318 & \\
\hline $\mathrm{H} 2 \mathrm{O}(\mathrm{kg} / \mathrm{h})$ & 1,851 & 229 & 1,061 & 1,061 & 1,061 & 1,061 & 1,061 & 1,061 & 1,061 & 320 \\
\hline $\mathrm{CH} 4$ (kg/h) & & & 136 & 136 & 136 & 136 & 136 & 136 & 136 & \\
\hline H2S (kg/h) & & & 1.62 & 1.62 & 1.62 & 1.62 & 1.62 & 1.62 & 1.62 & \\
\hline \multicolumn{11}{|l|}{$\mathrm{SO} 2(\mathrm{~kg} / \mathrm{h})$} \\
\hline $\mathrm{NH3}(\mathrm{kg} / \mathrm{h})$ & & & 3.57 & 3.57 & 3.57 & 3.57 & 3.57 & 3.57 & 3.57 & \\
\hline Tar - C10H8 (kg/h) & & & 30. & 30. & 30. & 30. & 30. & 30. & 30. & \\
\hline $\mathrm{C} 2 \mathrm{H} 2(\mathrm{~kg} / \mathrm{h})$ & & & 4.58 & 4.58 & 4.58 & 4.58 & 4.58 & 4.58 & 4.58 & \\
\hline $\mathrm{C} 2 \mathrm{H} 4(\mathrm{~kg} / \mathrm{h})$ & & & 68.9 & 68.9 & 68.9 & 68.9 & 68.9 & 68.9 & 68.9 & \\
\hline C2H6 (kg/h) & & & 8.71 & 8.71 & 8.71 & 8.71 & 8.71 & 8.71 & 8.71 & \\
\hline Sand (kg/h) & & & 37,561 & & & & & & & \\
\hline Char (kg/h) & & & 1,417 & & & & & & & \\
\hline Wood (kg/h) & 1,851 & 1,851 & & & & & & & & \\
\hline \multicolumn{11}{|l|}{ Ash $(\mathrm{kg} / \mathrm{h})$} \\
\hline Total (kg/h) & 3,701 & 2,079 & 41,303 & 2,326 & 2,326 & 2,326 & 2,326 & 2,326 & 2,326 & 320 \\
\hline
\end{tabular}




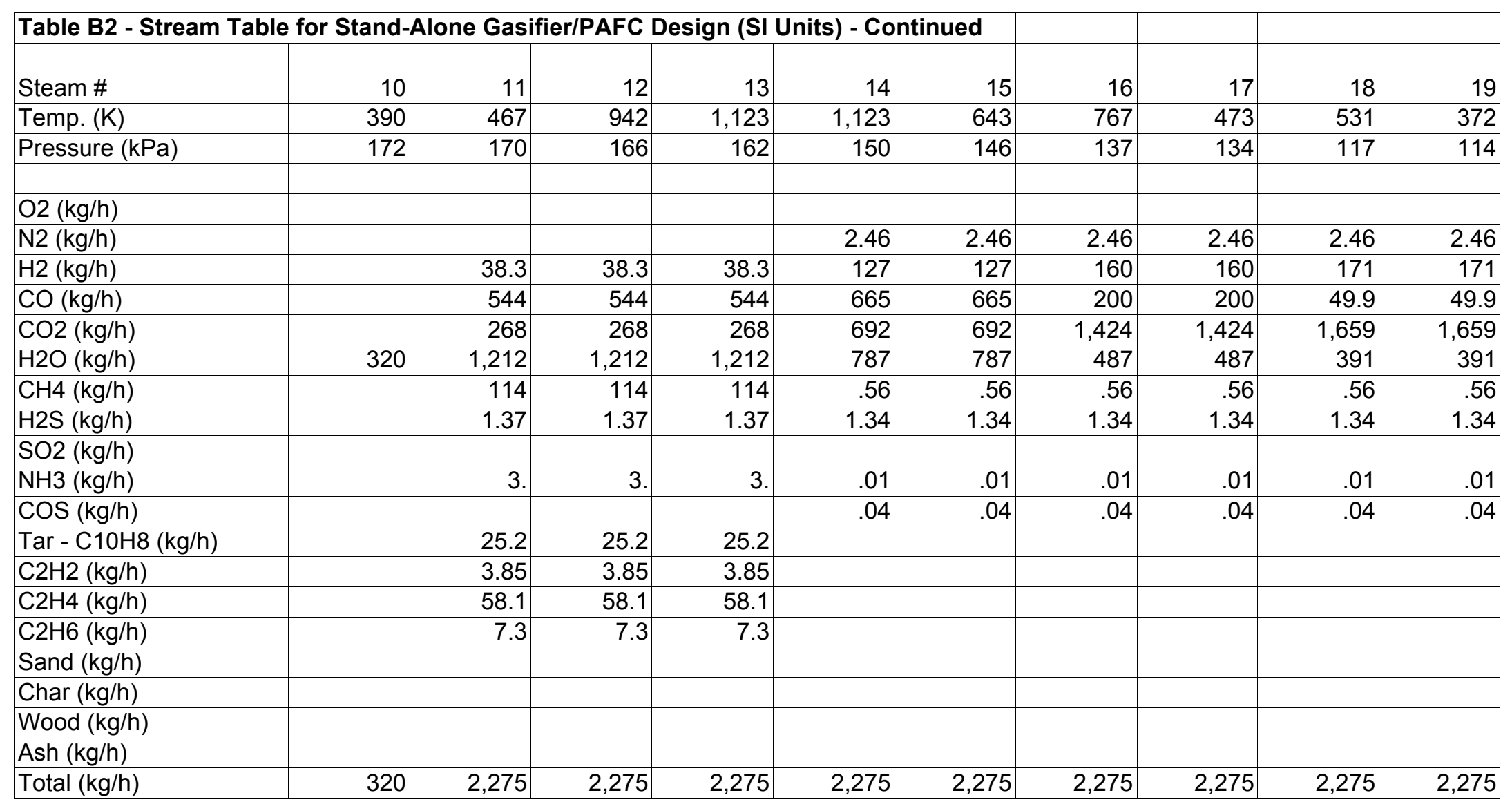




\begin{tabular}{|c|c|c|c|c|c|c|c|c|c|c|}
\hline \multicolumn{11}{|c|}{ Table B2 - Stream Table for Stand-Alone Gasifier/PAFC Design (SI Units) - Continued } \\
\hline Steam \# & 20 & 21 & 22 & 23 & 24 & 25 & 26 & 27 & 28 & 29 \\
\hline Temp. (K) & 372 & 467 & 434 & 288 & 315 & 422 & 1,691 & 1,038 & 817 & 501 \\
\hline Pressure $(\mathrm{kPa})$ & 114 & 157 & 123 & 101 & 128 & 123 & 123 & 119 & 115 & 111 \\
\hline $\mathrm{O} 2(\mathrm{~kg} / \mathrm{h})$ & & & 443 & 443 & 443 & 443 & 179 & 179 & 179 & 179 \\
\hline N2 (kg/h) & 2.46 & & 1,463 & 1,463 & 1,463 & 1,463 & 1,463 & 1,463 & 1,463 & 1,463 \\
\hline $\mathrm{CO}(\mathrm{kg} / \mathrm{h})$ & 49.9 & 103 & 103 & & & & & & & \\
\hline $\mathrm{CO} 2(\mathrm{~kg} / \mathrm{h})$ & 1,659 & 50.8 & 51.7 & .97 & .97 & .97 & 332 & 332 & 332 & 332 \\
\hline $\mathrm{H} 2 \mathrm{O}(\mathrm{kg} / \mathrm{h})$ & 391 & 170 & 181 & 12.2 & 12.2 & 12.2 & 316 & 316 & 316 & 316 \\
\hline $\mathrm{CH} 4(\mathrm{~kg} / \mathrm{h})$ & .56 & 21.6 & 21.6 & & & & & & & \\
\hline H2S (kg/h) & 1.34 & .26 & .26 & & & & & & & \\
\hline SO2 (kg/h) & & & & & & & .49 & .49 & .49 & .49 \\
\hline NH3 (kg/h) & .01 & .57 & .57 & & & & & & & \\
\hline Tar - C10H8 (kg/h) & & 4.81 & 4.81 & & & & & & & \\
\hline $\mathrm{C} 2 \mathrm{H} 2(\mathrm{~kg} / \mathrm{h})$ & & .73 & .73 & & & & & & & \\
\hline $\mathrm{C} 2 \mathrm{H} 4(\mathrm{~kg} / \mathrm{h})$ & & 11. & 11. & & & & & & & \\
\hline $\mathrm{C} 2 \mathrm{H} 6(\mathrm{~kg} / \mathrm{h})$ & & 1.39 & 1.39 & & & & & & & \\
\hline \multicolumn{11}{|l|}{ Sand (kg/h) } \\
\hline \multicolumn{11}{|l|}{ Char (kg/h) } \\
\hline \multicolumn{11}{|l|}{ Wood (kg/h) } \\
\hline \multicolumn{11}{|l|}{ Ash (kg/h) } \\
\hline Total $(\mathrm{kg} / \mathrm{h})$ & 2,275 & 372 & 2,290 & 1,919 & 1,919 & 1,919 & 2,291 & 2,291 & 2,291 & 2,291 \\
\hline
\end{tabular}


Table B2 - Stream Table for Stand-Alone Gasifier/PAFC Design (SI Units) - Continued

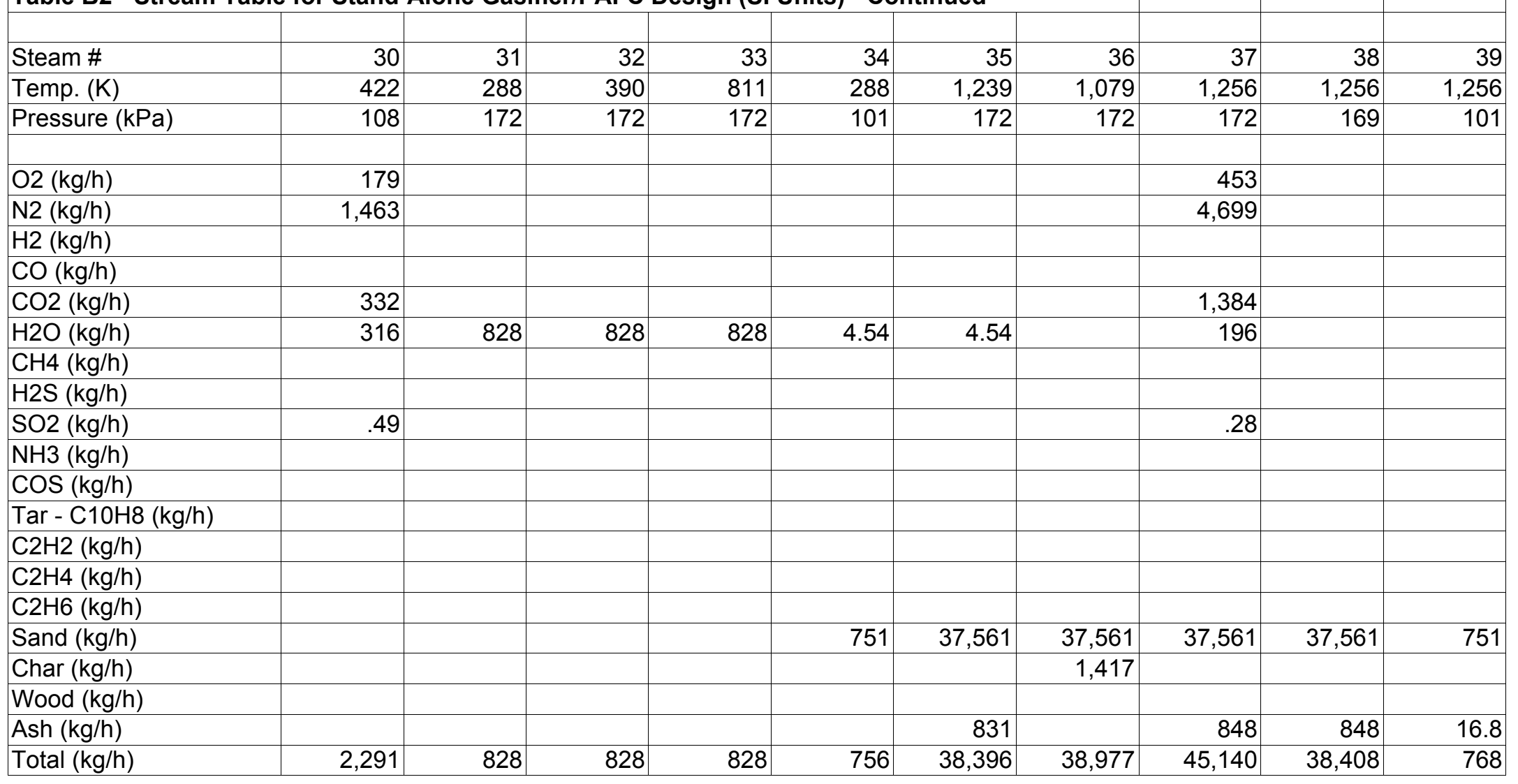




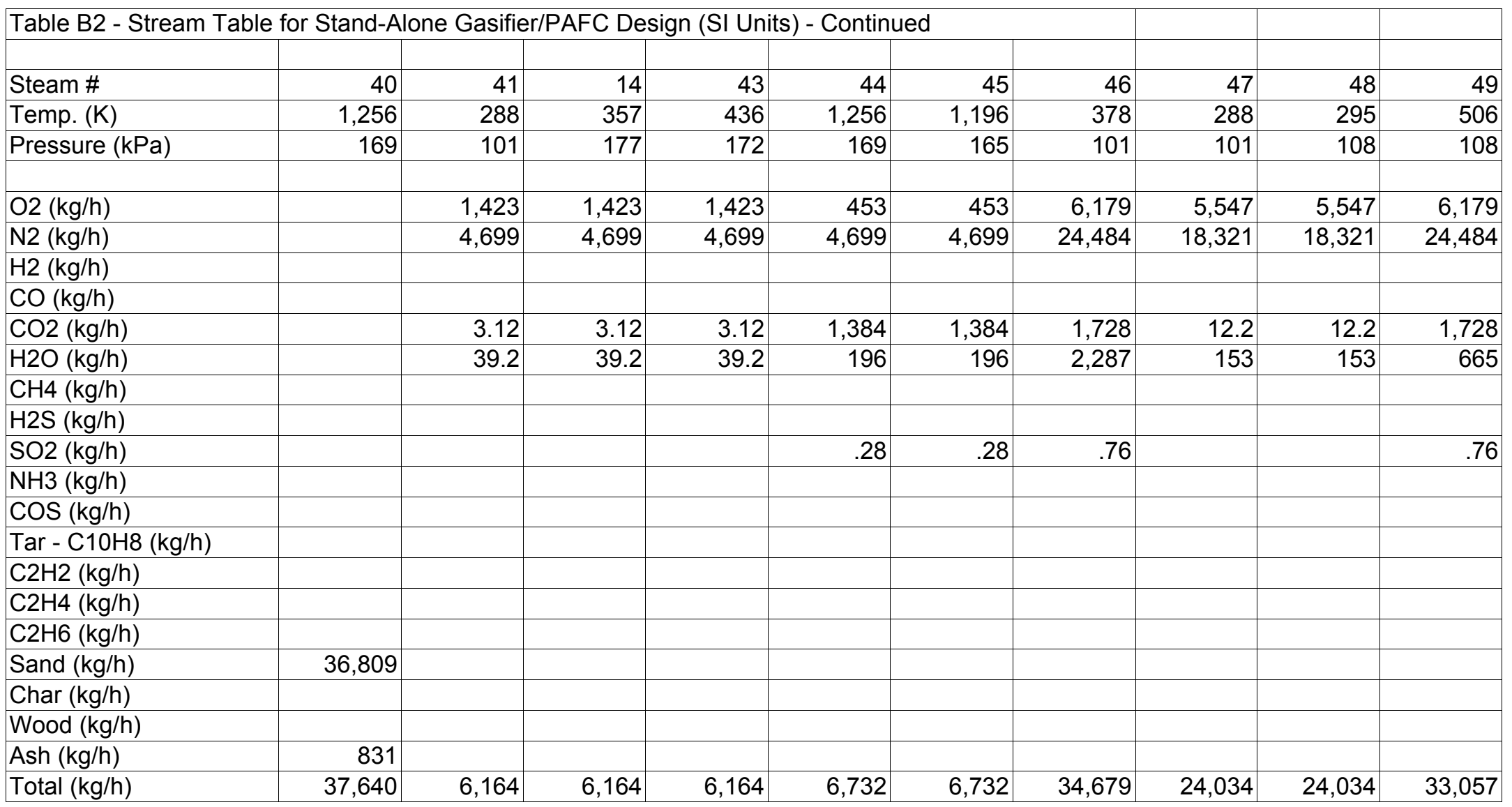




\begin{tabular}{|c|c|c|c|c|c|c|c|c|c|c|c|}
\hline \multicolumn{12}{|c|}{ Table B2 - Stream Table for Stand-Alone Gasifier/PAFC Design (SI Units) - Continued } \\
\hline & & & & & & & & & & & \\
\hline Steam \# & 50 & 51 & 52 & 53 & 54 & 55 & 56 & 57 & 58 & 59 & 60 \\
\hline Temp. (K) & 378 & 379 & 288 & 306 & 478 & 478 & 802 & 700 & 912 & 700 & 422 \\
\hline Pressure (kPa) & 105 & 101 & 101 & 117 & 115 & 115 & 111 & 111 & 109 & 105 & 101 \\
\hline $\mathrm{O} 2(\mathrm{~kg} / \mathrm{h})$ & 6,179 & 6,179 & 2,811 & 2,811 & & 1,704 & 1,704 & 1,704 & 1,451 & 1,451 & 1,451 \\
\hline N2 (kg/h) & 24,484 & 24,484 & 9,285 & 9,285 & 2.46 & 9,285 & 9,285 & 9,287 & 9,287 & 9,287 & 9,287 \\
\hline $\mathrm{H} 2(\mathrm{~kg} / \mathrm{h})$ & & & & & 34.9 & & & 34.9 & 3.49 & 3.49 & 3.49 \\
\hline \multicolumn{12}{|l|}{$\mathrm{CO}(\mathrm{kg} / \mathrm{h})$} \\
\hline CO2 (kg/h) & 1,728 & 1,728 & 6.17 & 6.17 & 1,737 & 6.17 & 6.17 & 1,744 & 1,745 & 1,745 & 1,745 \\
\hline $\mathrm{H} 2 \mathrm{O}(\mathrm{kg} / \mathrm{h})$ & 2,287 & 2,287 & 77.6 & 77.6 & 1,606 & 77.6 & 77.6 & 1,683 & 1,966 & 1,966 & 1,966 \\
\hline $\mathrm{CH} 4(\mathrm{~kg} / \mathrm{h})$ & & & & & .56 & & & .56 & .01 & .01 & .01 \\
\hline H2S (kg/h) & & & & & 1.34 & & & 1.34 & & & \\
\hline SO2 (kg/h) & .76 & .76 & & & & & & & 2.52 & 2.52 & 2.52 \\
\hline NH3 (kg/h) & & & & & .01 & & & .01 & & & \\
\hline $\operatorname{COS}(\mathrm{kg} / \mathrm{h})$ & & & & & .04 & & & .04 & .04 & .04 & .04 \\
\hline \multicolumn{12}{|c|}{ Tar - C10H8 (kg/h) } \\
\hline \multicolumn{12}{|c|}{$\mathrm{C} 2 \mathrm{H} 2(\mathrm{~kg} / \mathrm{h})$} \\
\hline \multicolumn{12}{|l|}{$\mathrm{C} 2 \mathrm{H} 4(\mathrm{~kg} / \mathrm{h})$} \\
\hline \multicolumn{12}{|l|}{ C2H6 (kg/h) } \\
\hline \multicolumn{12}{|l|}{ Sand $(\mathrm{kg} / \mathrm{h})$} \\
\hline \multicolumn{12}{|l|}{ Char (kg/h) } \\
\hline \multicolumn{12}{|l|}{ Wood (kg/h) } \\
\hline \multicolumn{12}{|l|}{ Ash (kg/h) } \\
\hline Total $(\mathrm{kg} / \mathrm{h})$ & 34,679 & 34,679 & 12,180 & 12,180 & 3,383 & 11,072 & 11,072 & 14,454 & 14,454 & 14,454 & 14,454 \\
\hline
\end{tabular}


Figure B4 - Integrated Gasifier Flowsheet

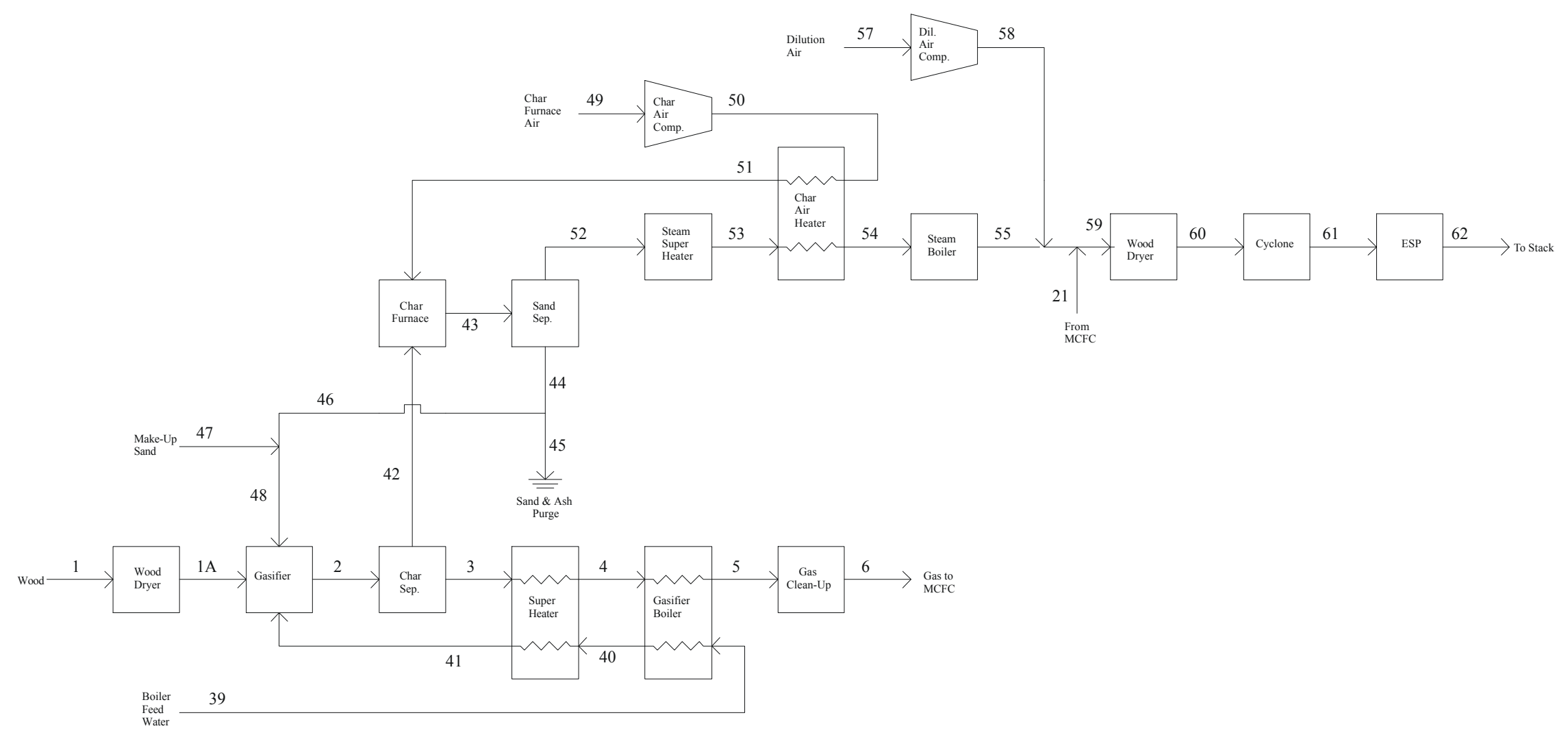


Figure B5 - Integrated MCFC Flowsheet

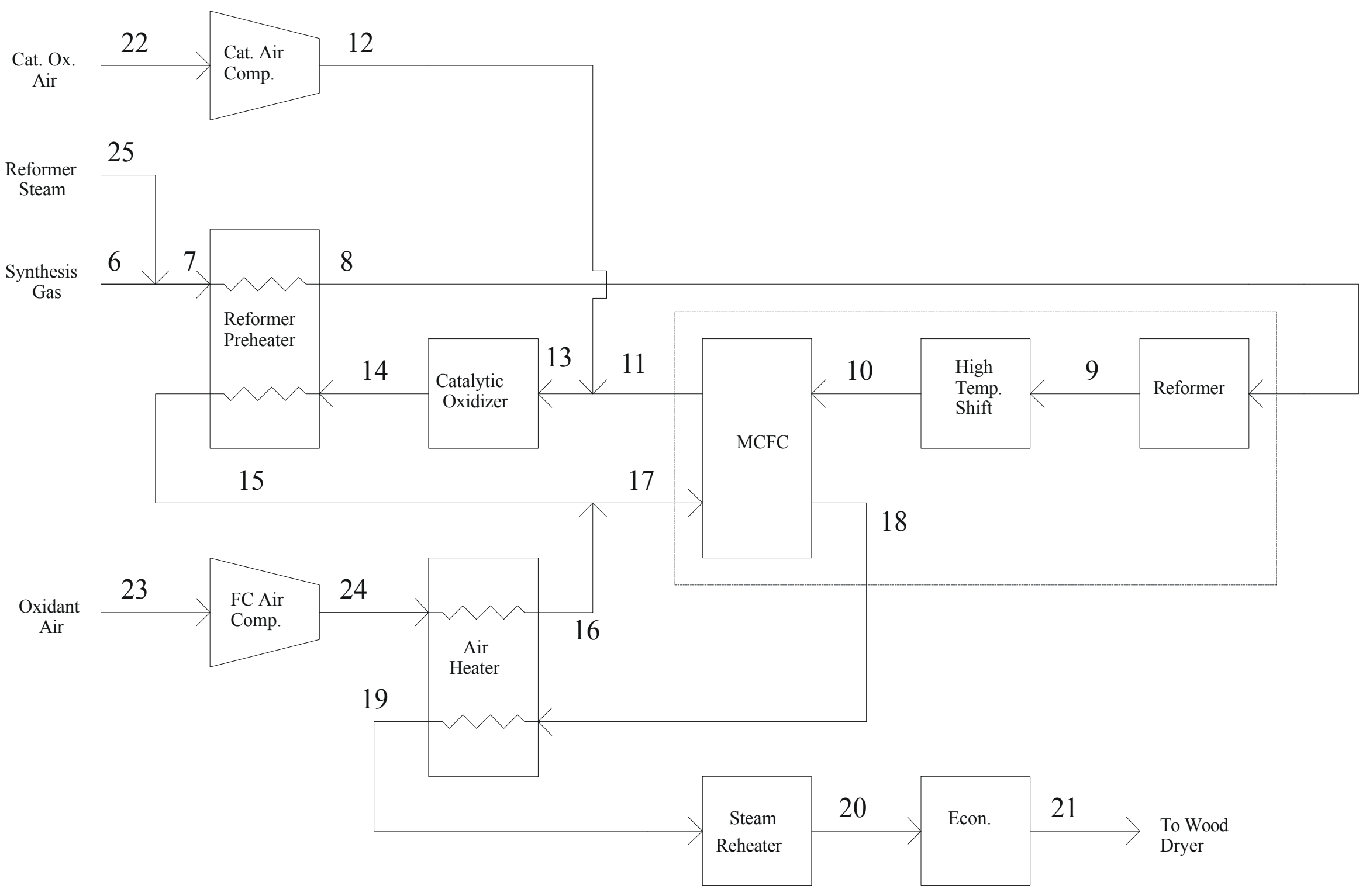


Figure B6 - Integrated Steam Cycle Flowsheet

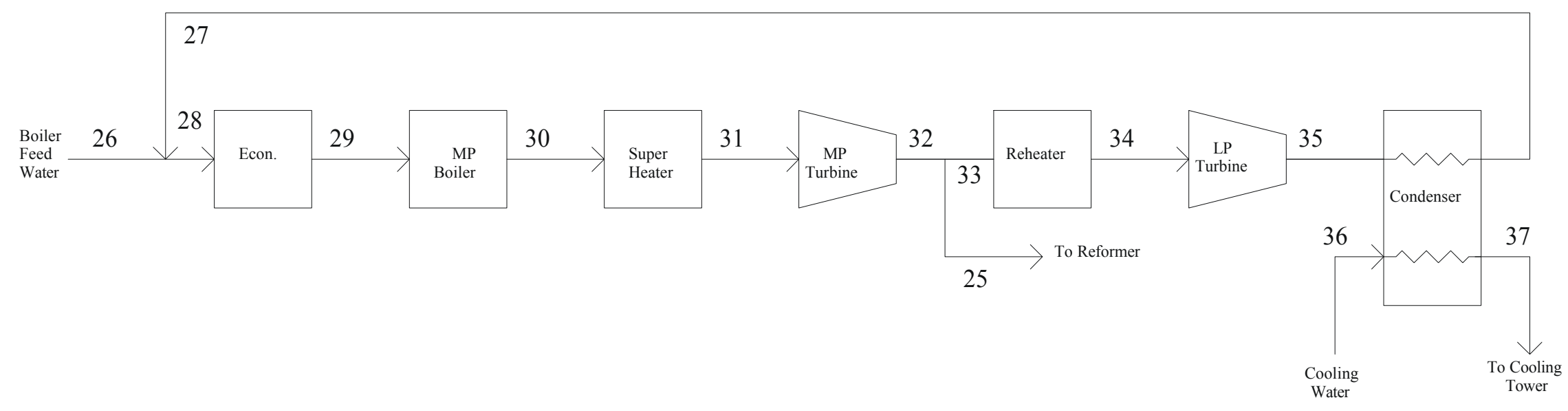




\begin{tabular}{|c|c|c|c|c|c|c|c|c|c|c|}
\hline \multicolumn{11}{|c|}{ Table B3 - Stream Table for Integrated Gasifier/MCFC Design (English Units) } \\
\hline & & & & & & & & & & \\
\hline Steam \# & 1 & $1 \mathrm{~A}$ & 2 & 3 & 4 & 5 & 6 & 7 & 8 & 9 \\
\hline Temp. $\left({ }^{\circ} \mathrm{F}\right)$ & 59 & 80 & 1500 & 1500 & 1262 & 413 & 413 & 398 & 1202 & 1202 \\
\hline \multirow[t]{2}{*}{ Pressure (psia) } & 14.7 & 14.7 & 25 & 24.5 & 23.9 & 23.4 & 23.4 & 22.7 & 22.1 & 21.7 \\
\hline & & & & & & & & & & \\
\hline \multicolumn{11}{|l|}{$\mathrm{O} 2(\mathrm{lb} / \mathrm{h})$} \\
\hline N2 (lb/h) & & & & & & & & & & 6.42 \\
\hline $\mathrm{H} 2$ (Ib/h) & & & 99.2 & 99.2 & 99.2 & 99.2 & 99.2 & 99.2 & 99.2 & 309 \\
\hline $\mathrm{CO}(\mathrm{lb} / \mathrm{h})$ & & & 1,465 & 1,465 & 1,465 & 1,465 & 1,465 & 1,465 & 1,465 & 1,044 \\
\hline $\mathrm{CO} 2(\mathrm{lb} / \mathrm{h})$ & & & 720 & 720 & 720 & 720 & 720 & 720 & 720 & 2,586 \\
\hline $\mathrm{H} 2 \mathrm{O}(\mathrm{lb} / \mathrm{h})$ & 4,080 & 504 & 2,339 & 2,339 & 2,339 & 2,339 & 2,339 & 3,265 & 3,265 & 2,007 \\
\hline $\mathrm{CH} 4$ (Ib/h) & & & 307 & 307 & 307 & 307 & 307 & 307 & 307 & 161 \\
\hline $\mathrm{H} 2 \mathrm{~S}$ (Ib/h) & & & 3.58 & 3.58 & 3.58 & 3.58 & 3.58 & 3.58 & 3.58 & 3.54 \\
\hline \multicolumn{11}{|l|}{ SO2 (lb/h) } \\
\hline $\mathrm{NH3}(\mathrm{lb} / \mathrm{h})$ & & & 7.88 & 7.88 & 7.88 & 7.88 & 7.88 & 7.88 & 7.88 & .07 \\
\hline COS (lb/h) & & & & & & & & & & .08 \\
\hline Tar - C10H8 (lb/h) & & & 64.7 & 64.7 & 64.7 & 64.7 & 64.7 & 64.7 & 64.7 & \\
\hline $\mathrm{C} 2 \mathrm{H} 2(\mathrm{lb} / \mathrm{h})$ & & & 10.9 & 10.9 & 10.9 & 10.9 & 10.9 & 10.9 & 10.9 & \\
\hline $\mathrm{C} 2 \mathrm{H} 4$ (Ib/h) & & & 157 & 157 & 157 & 157 & 157 & 157 & 157 & \\
\hline $\mathrm{C} 2 \mathrm{H} 6$ (Ib/h) & & & 18.2 & 18.2 & 18.2 & 18.2 & 18.2 & 18.2 & 18.2 & \\
\hline Sand (lb/h) & & & 87,926 & & & & & & & \\
\hline Char (Ib/h) & & & 3,060 & & & & & & & \\
\hline Wood (lb/h) & 4,080 & 4,080 & & & & & & & & \\
\hline \multicolumn{11}{|l|}{ Ash (lb/h) } \\
\hline Total $(\mathrm{lb} / \mathrm{h})$ & 8,160 & 4,584 & 96,178 & 5,192 & 5,192 & 5,192 & 5,192 & 6,118 & 6,118 & 6,117 \\
\hline \multicolumn{11}{|l|}{ O2 (mol. frac.) } \\
\hline N2 (mol. frac.) & & & & & & & & & & $6.18 \mathrm{E}-4$ \\
\hline H2 (mol. frac.) & & & 0.179 & 0.179 & 0.179 & 0.179 & 0.179 & 0.151 & 0.151 & 0.413 \\
\hline $\mathrm{CO}$ (mol. frac.) & & & 0.190 & 0.190 & 0.190 & 0.190 & 0.190 & 0.160 & 0.160 & 0.100 \\
\hline CO2 (mol. frac.) & & & 0.060 & 0.060 & 0.060 & 0.060 & 0.060 & 0.050 & 0.050 & 0.158 \\
\hline $\mathrm{H} 2 \mathrm{O}$ (mol. frac.) & & & 0.473 & 0.473 & 0.473 & 0.473 & 0.473 & 0.556 & 0.556 & 0.300 \\
\hline $\mathrm{CH} 4$ (mol. frac.) & & & 0.070 & 0.070 & 0.070 & 0.070 & 0.070 & 0.059 & 0.059 & 0.027 \\
\hline H2S (mol. frac.) & & & $3.83 \mathrm{E}-4$ & $3.83 \mathrm{E}-4$ & $3.83 \mathrm{E}-4$ & $3.83 E-4$ & $3.83 E-4$ & $3.22 \mathrm{E}-4$ & $3.22 \mathrm{E}-4$ & $2.79 \mathrm{E}-4$ \\
\hline \multicolumn{11}{|l|}{ SO2 (mol. frac.) } \\
\hline NH3 (mol. frac.) & & & 0.002 & 0.002 & 0.002 & 0.002 & 0.002 & 0.001 & 0.001 & 1.09E-5 \\
\hline COS (mol. frac.) & & & & & & & & & & $3.47 \mathrm{E}-6$ \\
\hline Tar - C10H8 (mol. frac.) & & & 0.002 & 0.002 & 0.002 & 0.002 & 0.002 & 0.002 & 0.002 & \\
\hline $\mathrm{C} 2 \mathrm{H} 2$ (mol. frac.) & & & 0.002 & 0.002 & 0.002 & 0.002 & 0.002 & 0.001 & 0.001 & \\
\hline $\mathrm{C} 2 \mathrm{H} 4$ (mol. frac.) & & & 0.020 & 0.020 & 0.020 & 0.020 & 0.020 & 0.017 & 0.017 & \\
\hline $\mathrm{C} 2 \mathrm{H} 6$ (mol. frac.) & & & 0.002 & 0.002 & 0.002 & 0.002 & 0.002 & 0.002 & 0.002 & \\
\hline
\end{tabular}




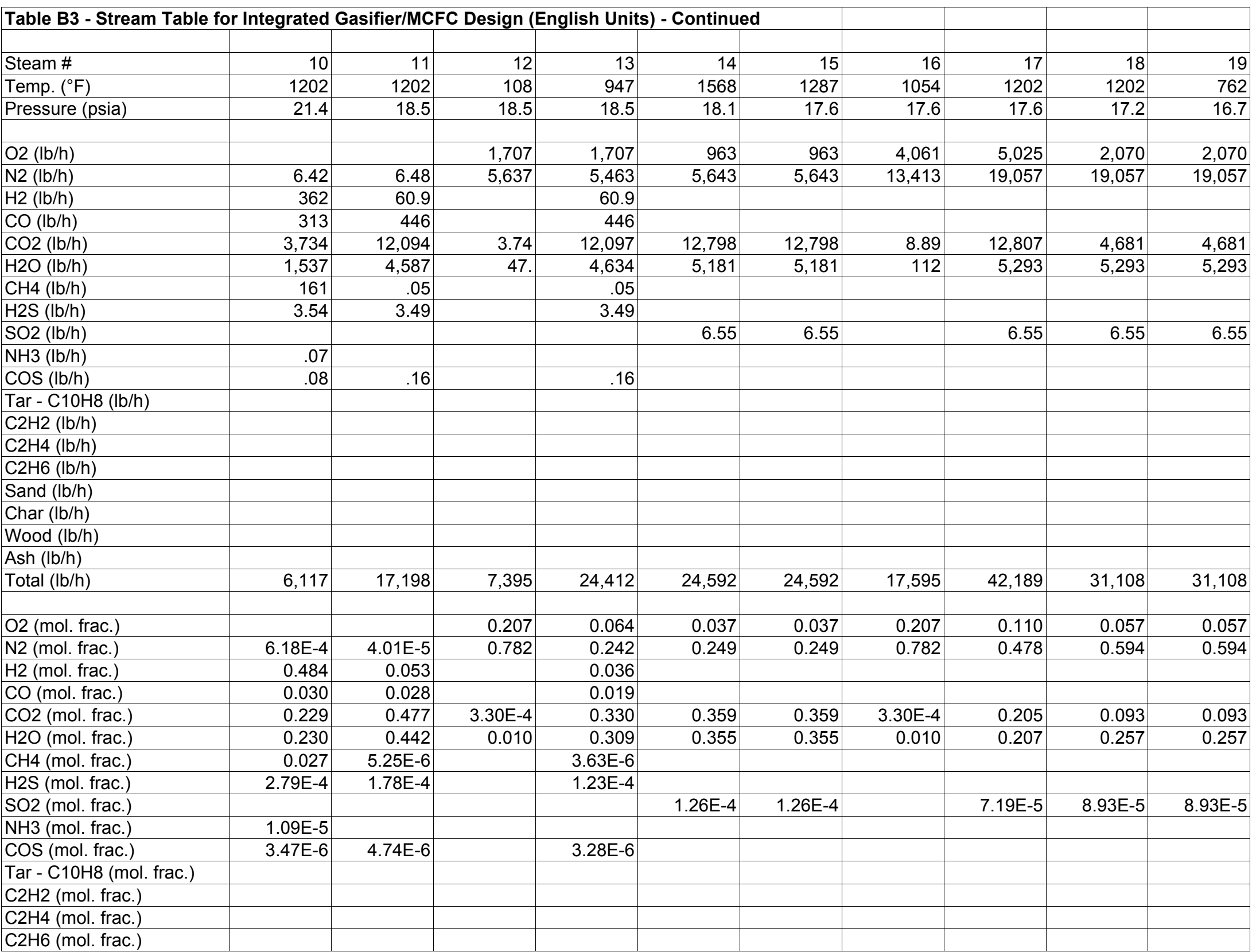




\begin{tabular}{|c|c|c|c|c|c|c|c|c|c|c|}
\hline \multicolumn{11}{|c|}{ Table B3 - Stream Table for Integrated Gasifier/MCFC Design (English Units) - Continued } \\
\hline Steam \# & 20 & 21 & 22 & 23 & 24 & 25 & 26 & 27 & 28 & 29 \\
\hline Temp. $\left({ }^{\circ} \mathrm{F}\right)$ & 672 & 507 & 59 & 59 & 108 & 339 & 59 & 144 & 139 & 300 \\
\hline Pressure (psia) & 16.1 & 15.6 & 14.7 & 14.7 & 18.4 & 115 & 25 & 25 & 515 & 515 \\
\hline $\mathrm{O} 2(\mathrm{lb} / \mathrm{h})$ & 2,070 & 2,070 & 1,707 & 4,061 & 4,061 & & & & & \\
\hline N2 (lb/h) & 19,057 & 19,057 & 5,637 & 13,413 & 13,413 & & & & & \\
\hline \multicolumn{11}{|l|}{$\mathrm{H} 2$ (lb/h) } \\
\hline \multicolumn{11}{|l|}{$\mathrm{CO}(\mathrm{lb} / \mathrm{h})$} \\
\hline $\mathrm{CO} 2(\mathrm{lb} / \mathrm{h})$ & 4,681 & 4,681 & 3.74 & 8.89 & 8.89 & & & & & \\
\hline $\mathrm{H} 2 \mathrm{O}(\mathrm{lb} / \mathrm{h})$ & 5,293 & 5,293 & 47. & 112 & 112 & 925 & 925 & 7,561 & 8,487 & 8,487 \\
\hline \multicolumn{11}{|l|}{$\mathrm{CH} 4$ (Ib/h) } \\
\hline \multicolumn{11}{|l|}{$\mathrm{H} 2 \mathrm{~S}$ (Ib/h) } \\
\hline $\mathrm{SO} 2(\mathrm{lb} / \mathrm{h})$ & 6.55 & 6.55 & & & & & & & & \\
\hline \multicolumn{11}{|l|}{$\mathrm{NH} 3(\mathrm{lb} / \mathrm{h})$} \\
\hline \multicolumn{11}{|l|}{$\cos (\mathrm{lb} / \mathrm{h})$} \\
\hline \multicolumn{11}{|l|}{ Tar - C10H8 (lb/h) } \\
\hline \multicolumn{11}{|l|}{$\mathrm{C} 2 \mathrm{H} 2(\mathrm{lb} / \mathrm{h})$} \\
\hline \multicolumn{11}{|l|}{$\mathrm{C} 2 \mathrm{H} 4$ (Ib/h) } \\
\hline \multicolumn{11}{|l|}{$\mathrm{C} 2 \mathrm{H} 6(\mathrm{lb} / \mathrm{h})$} \\
\hline \multicolumn{11}{|l|}{ Sand (lb/h) } \\
\hline \multicolumn{11}{|l|}{ Char (Ib/h) } \\
\hline \multicolumn{11}{|l|}{ Wood (lb/h) } \\
\hline \multicolumn{11}{|l|}{ Ash (Ib/h) } \\
\hline Total $(\mathrm{lb} / \mathrm{h})$ & 31,108 & 31,108 & 7,395 & 17,595 & 17,595 & 925 & 925 & 7,561 & 8,487 & 8,487 \\
\hline & & & & & & & & & & \\
\hline $\mathrm{O} 2$ (mol. frac.) & 0.057 & 0.057 & 0.207 & 0.207 & 0.207 & & & & & \\
\hline $\mathrm{N} 2$ (mol. frac.) & 0.594 & 0.594 & 0.782 & 0.782 & 0.782 & & & & & \\
\hline \multicolumn{11}{|l|}{ H2 (mol. frac.) } \\
\hline \multicolumn{11}{|l|}{ CO (mol. frac.) } \\
\hline CO2 (mol. frac.) & 0.093 & 0.093 & 3.30E-4 & $3.30 \mathrm{E}-4$ & 3.30E-4 & & & & & \\
\hline $\mathrm{H} 2 \mathrm{O}$ (mol. frac.) & 0.257 & 0.257 & 0.010 & 0.010 & 0.010 & & & & & \\
\hline \multicolumn{11}{|l|}{$\mathrm{CH} 4$ (mol. frac.) } \\
\hline \multicolumn{11}{|l|}{ H2S (mol. frac.) } \\
\hline SO2 (mol. frac.) & 8.93E-5 & 8.93E-5 & & & & & & & & \\
\hline \multicolumn{11}{|l|}{ NH3 (mol. frac.) } \\
\hline \multicolumn{11}{|c|}{ COS (mol. frac.) } \\
\hline \multicolumn{11}{|c|}{ Tar - C10H8 (mol. frac.) } \\
\hline \multicolumn{11}{|c|}{$\mathrm{C} 2 \mathrm{H} 2$ (mol. frac.) } \\
\hline \multicolumn{11}{|l|}{$\mathrm{C} 2 \mathrm{H} 4$ (mol. frac.) } \\
\hline C2H6 (mol. frac.) & & & & & & & & & & \\
\hline
\end{tabular}




\begin{tabular}{|c|c|c|c|c|c|c|c|c|c|}
\hline \multicolumn{10}{|c|}{ Table B3 - Stream Table for Integrated Gasifier/MCFC Design (English Units) - Continued } \\
\hline Steam \# & 30 & 31 & 32 & 33 & 34 & 35 & 36 & 37 & 39 \\
\hline Temp. $\left({ }^{\circ} \mathrm{F}\right)$ & 470 & 619 & 362 & 362 & 589 & 145 & 110 & 125 & 59 \\
\hline Pressure (psia) & 515 & 515 & 115 & 115 & 115 & 3 & 50 & 50 & 25 \\
\hline & & & & & & & & & \\
\hline \multicolumn{10}{|l|}{$\mathrm{O} 2(\mathrm{Ib} / \mathrm{h})$} \\
\hline \multicolumn{10}{|l|}{ N2 (Ib/h) } \\
\hline \multicolumn{10}{|l|}{$\mathrm{H} 2$ (lb/h) } \\
\hline \multicolumn{10}{|l|}{$\mathrm{CO}(\mathrm{lb} / \mathrm{h})$} \\
\hline \multicolumn{10}{|l|}{ CO2 (lb/h) } \\
\hline $\mathrm{H} 2 \mathrm{O}(\mathrm{lb} / \mathrm{h})$ & 8,487 & 8,487 & 8,487 & 7,561 & 7,561 & 7,561 & 520,628 & 520,628 & 1,825 \\
\hline \multicolumn{10}{|l|}{$\mathrm{CH} 4(\mathrm{lb} / \mathrm{h})$} \\
\hline \multicolumn{10}{|l|}{$\mathrm{H} 2 \mathrm{~S}$ (Ib/h) } \\
\hline \multicolumn{10}{|l|}{$\mathrm{SO} 2(\mathrm{lb} / \mathrm{h})$} \\
\hline \multicolumn{10}{|l|}{$\mathrm{NH3}(\mathrm{lb} / \mathrm{h})$} \\
\hline \multicolumn{10}{|l|}{$\cos (\mathrm{lb} / \mathrm{h})$} \\
\hline \multicolumn{10}{|l|}{ Tar - C10H8 (lb/h) } \\
\hline \multicolumn{10}{|l|}{$\mathrm{C} 2 \mathrm{H} 2(\mathrm{lb} / \mathrm{h})$} \\
\hline \multicolumn{10}{|l|}{$\mathrm{C} 2 \mathrm{H} 4(\mathrm{lb} / \mathrm{h})$} \\
\hline \multicolumn{10}{|l|}{$\mathrm{C} 2 \mathrm{H} 6(\mathrm{lb} / \mathrm{h})$} \\
\hline \multicolumn{10}{|l|}{ Sand $(\mathrm{lb} / \mathrm{h})$} \\
\hline \multicolumn{10}{|l|}{ Char (lb/h) } \\
\hline \multicolumn{10}{|l|}{ Wood (lb/h) } \\
\hline \multicolumn{10}{|l|}{ Ash (Ib/h) } \\
\hline Total $(\mathrm{lb} / \mathrm{h})$ & 8,487 & 8,487 & 8,487 & 7,561 & 7,561 & 7,561 & 520,628 & 520,628 & 1,825 \\
\hline & & & & & & & & & \\
\hline \multicolumn{10}{|l|}{$\mathrm{O} 2$ (mol. frac.) } \\
\hline \multicolumn{10}{|l|}{$\mathrm{N} 2$ (mol. frac.) } \\
\hline \multicolumn{10}{|l|}{$\mathrm{H} 2$ (mol. frac.) } \\
\hline \multicolumn{10}{|l|}{$\mathrm{CO}$ (mol. frac.) } \\
\hline \multicolumn{10}{|l|}{ CO2 (mol. frac.) } \\
\hline H2O (mol. frac.) & & & & & & & & & \\
\hline $\mathrm{CH} 4$ (mol. frac.) & & & & & & & & & \\
\hline H2S (mol. frac.) & & & & & & & & & \\
\hline SO2 (mol. frac.) & & & & & & & & & \\
\hline NH3 (mol. frac.) & & & & & & & & & \\
\hline COS (mol. frac.) & & & & & & & & & \\
\hline Tar - C10H8 $(\mathrm{mol}$ & & & & & & & & & \\
\hline $\mathrm{C} 2 \mathrm{H} 2$ (mol. frac.) & & & & & & & & & \\
\hline $\mathrm{C} 2 \mathrm{H} 4$ (mol. frac.) & & & & & & & & & \\
\hline C2H6 (mol. frac.) & & & & & & & & & \\
\hline
\end{tabular}




\begin{tabular}{|c|c|c|c|c|c|c|c|c|c|c|}
\hline \multicolumn{11}{|c|}{ Table B3 - Stream Table for Integrated Gasifier/MCFC Design (English Units) - Continued } \\
\hline & & & & & & & & & & \\
\hline Steam \# & 40 & 41 & 42 & 43 & 44 & 45 & 46 & 47 & 48 & 49 \\
\hline Temp. $\left({ }^{\circ} \mathrm{F}\right)$ & 242 & 1000 & 1500 & 1800 & 1800 & 1800 & 1800 & 59 & 1770 & 59 \\
\hline Pressure (psia) & 25 & 25 & 24.5 & 25 & 24.5 & 14.7 & 24.5 & 14.7 & 24.5 & 14.7 \\
\hline & & & & & & & & & & \\
\hline $\mathrm{O} 2(\mathrm{lb} / \mathrm{h})$ & & & & 944 & & & & & & 3,027 \\
\hline $\mathrm{N} 2$ (lb/h) & & & & 9,998 & & & & & & 9,998 \\
\hline \multicolumn{11}{|l|}{$\mathrm{H} 2(\mathrm{lb} / \mathrm{h})$} \\
\hline \multicolumn{11}{|l|}{$\mathrm{CO}(\mathrm{lb} / \mathrm{h})$} \\
\hline $\mathrm{CO} 2(\mathrm{lb} / \mathrm{h})$ & & & & 2,946 & & & & & & 6.63 \\
\hline $\mathrm{H} 2 \mathrm{O}(\mathrm{lb} / \mathrm{h})$ & 1,825 & 1,825 & & 417 & & & & 10. & 10. & 83.4 \\
\hline \multicolumn{11}{|l|}{$\mathrm{CH} 4(\mathrm{lb} / \mathrm{h})$} \\
\hline \multicolumn{11}{|l|}{$\mathrm{H} 2 \mathrm{~S}(\mathrm{lb} / \mathrm{h})$} \\
\hline $\mathrm{SO} 2(\mathrm{lb} / \mathrm{h})$ & & & & .61 & & & & & & \\
\hline \multicolumn{11}{|l|}{$\mathrm{NH3}(\mathrm{lb} / \mathrm{h})$} \\
\hline \multicolumn{11}{|l|}{$\cos (\mathrm{lb} / \mathrm{h})$} \\
\hline \multicolumn{11}{|l|}{ Tar - C10H8 (Ib/h) } \\
\hline \multicolumn{11}{|l|}{$\mathrm{C} 2 \mathrm{H} 2(\mathrm{lb} / \mathrm{h})$} \\
\hline \multicolumn{11}{|l|}{$\mathrm{C} 2 \mathrm{H} 4$ (lb/h) } \\
\hline \multicolumn{11}{|l|}{ C2H6 (lb/h) } \\
\hline Sand $(\mathrm{lb} / \mathrm{h})$ & & & 87,926 & 87,926 & 87,926 & 1,759 & 86,167 & 1,759 & 87,926 & \\
\hline Char (lb/h) & & & 3,060 & & & & & & & \\
\hline \multicolumn{11}{|l|}{ Wood (lb/h) } \\
\hline Ash (lb/h) & & & & 1,870 & 1,870 & 37.4 & 1,833 & & 1,833 & \\
\hline Total (lb/h) & 1,825 & 1,825 & 90,986 & 104,102 & 89,796 & 1,796 & 88,000 & 1,769 & 89,769 & 13,115 \\
\hline & & & & & & & & & & \\
\hline O2 (mol. frac.) & & & & 0.062 & & & & & & 0.207 \\
\hline N2 (mol. frac.) & & & & 0.749 & & & & & & 0.782 \\
\hline \multicolumn{11}{|l|}{$\mathrm{H} 2$ (mol. frac.) } \\
\hline \multicolumn{11}{|l|}{$\mathrm{CO}$ (mol. frac.) } \\
\hline CO2 (mol. frac.) & & & & 0.140 & & & & & & 3.30E-4 \\
\hline $\mathrm{H} 2 \mathrm{O}$ (mol. frac.) & & & & 0.049 & & & & & & 0.010 \\
\hline \multicolumn{11}{|l|}{$\mathrm{CH} 4$ (mol. frac.) } \\
\hline \multicolumn{11}{|l|}{ H2S (mol. frac.) } \\
\hline SO2 (mol. frac.) & & & & $2.00 \mathrm{E}-5$ & & & & & & \\
\hline \multicolumn{11}{|l|}{$\mathrm{NH} 3$ (mol. frac.) } \\
\hline \multicolumn{11}{|l|}{ COS (mol. frac.) } \\
\hline \multicolumn{11}{|c|}{ Tar - C10H8 (mol. frac.) } \\
\hline \multicolumn{11}{|c|}{$\mathrm{C} 2 \mathrm{H} 2$ (mol. frac.) } \\
\hline \multicolumn{11}{|l|}{$\mathrm{C} 2 \mathrm{H} 4$ (mol. frac.) } \\
\hline C2H6 (mol. frac.) & & & & & & & & & & \\
\hline
\end{tabular}




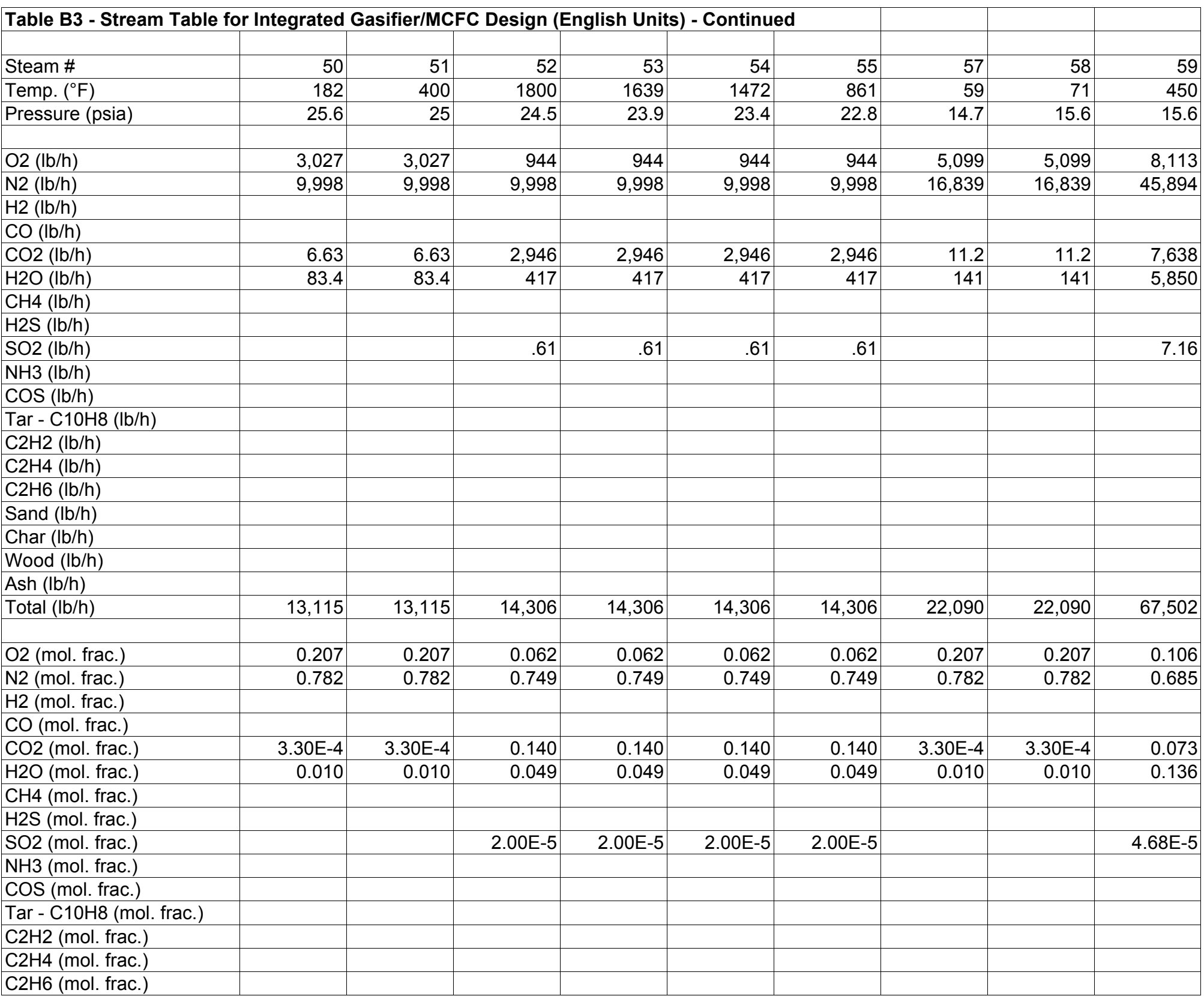




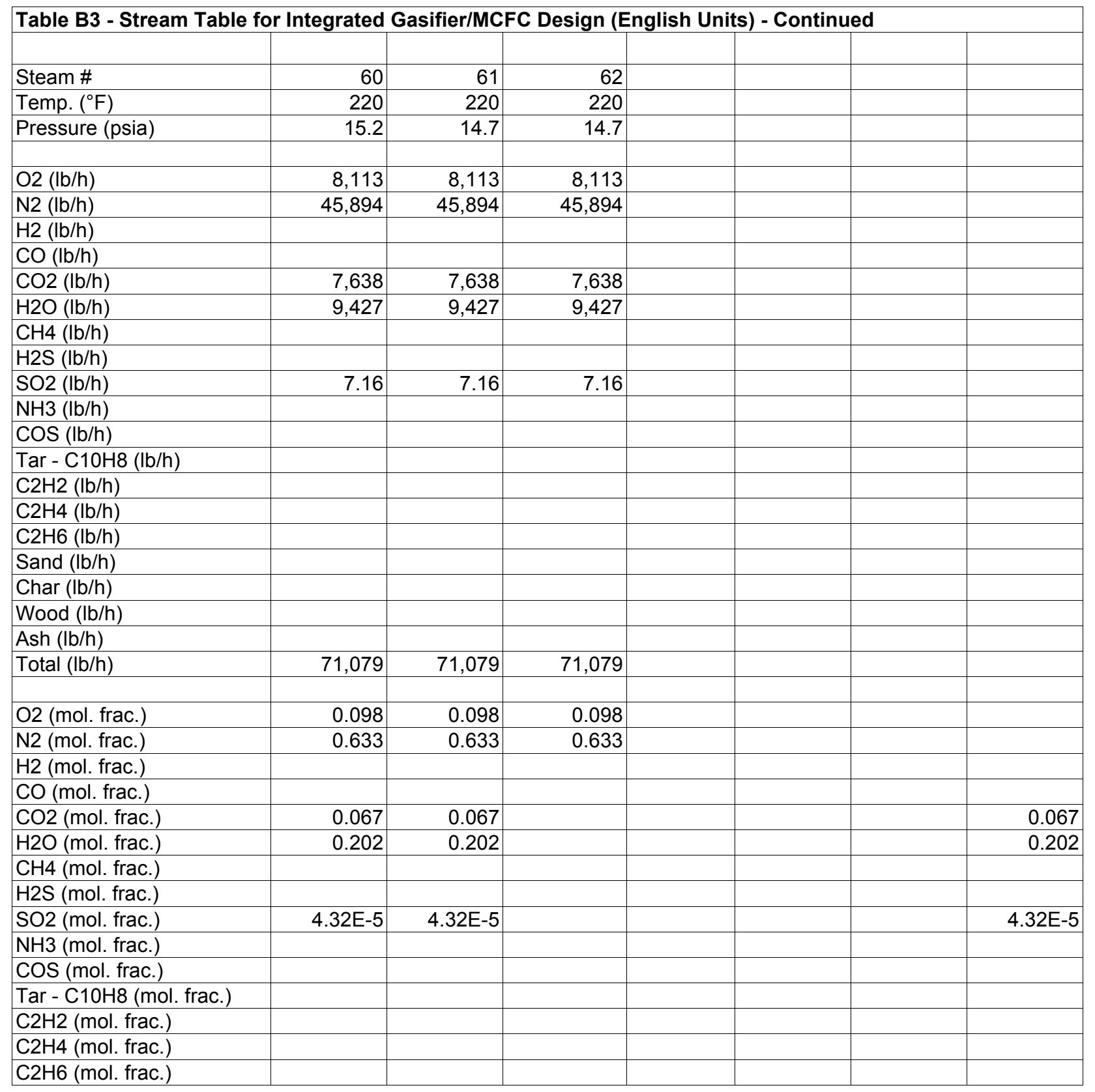




\begin{tabular}{|c|c|c|c|c|c|c|c|c|c|c|}
\hline \multicolumn{11}{|c|}{ Table B4 - Stream Table for Integrated Gasifier/MCFC Design (SI Units) } \\
\hline & & & & & & & & & & \\
\hline Steam \# & 1 & $1 \mathrm{~A}$ & 2 & 3 & 4 & 5 & 6 & 7 & 8 & 9 \\
\hline Temp. (K) & 288 & 300 & 1,089 & 1,089 & 957 & 485 & 485 & 477 & 923 & 923 \\
\hline Pressure (kPa) & 101 & 101 & 172 & 169 & 165 & 161 & 161 & 157 & 152 & 150 \\
\hline \multirow{2}{*}{\multicolumn{11}{|c|}{$\mathrm{O} 2(\mathrm{~kg} / \mathrm{h})$}} \\
\hline & & & & & & & & & & \\
\hline $\mathrm{N} 2(\mathrm{~kg} / \mathrm{h})$ & & & & & & & & & & 2.91 \\
\hline $\mathrm{H} 2(\mathrm{~kg} / \mathrm{h})$ & & & 45. & 45. & 45. & 45. & 45. & 45. & 45. & 140 \\
\hline $\mathrm{CO}(\mathrm{kg} / \mathrm{h})$ & & & 665 & 665 & 665 & 665 & 665 & 665 & 665 & 474 \\
\hline $\mathrm{CO} 2(\mathrm{~kg} / \mathrm{h})$ & & & 327 & 327 & 327 & 327 & 327 & 327 & 327 & 1,173 \\
\hline $\mathrm{H} 2 \mathrm{O}(\mathrm{kg} / \mathrm{h})$ & 1,851 & 229 & 1,061 & 1,061 & 1,061 & 1,061 & 1,061 & 1,481 & 1,481 & 910 \\
\hline $\mathrm{CH} 4(\mathrm{~kg} / \mathrm{h})$ & & & 139 & 139 & 139 & 139 & 139 & 139 & 139 & 73. \\
\hline $\mathrm{H} 2 \mathrm{~S}(\mathrm{~kg} / \mathrm{h})$ & & & 1.62 & 1.62 & 1.62 & 1.62 & 1.62 & 1.62 & 1.62 & 1.61 \\
\hline \multicolumn{11}{|l|}{ SO2 (kg/h) } \\
\hline $\mathrm{NH} 3(\mathrm{~kg} / \mathrm{h})$ & & & 3.57 & 3.57 & 3.57 & 3.57 & 3.57 & 3.57 & 3.57 & .03 \\
\hline $\cos (\mathrm{kg} / \mathrm{h})$ & & & & & & & & & & .04 \\
\hline Tar - C10H8 (kg/h) & & & 29.3 & 29.3 & 29.3 & 29.3 & 29.3 & 29.3 & 29.3 & \\
\hline $\mathrm{C} 2 \mathrm{H} 2(\mathrm{~kg} / \mathrm{h})$ & & & 4.94 & 4.94 & 4.94 & 4.94 & 4.94 & 4.94 & 4.94 & \\
\hline $\mathrm{C} 2 \mathrm{H} 4(\mathrm{~kg} / \mathrm{h})$ & & & 71.2 & 71.2 & 71.2 & 71.2 & 71.2 & 71.2 & 71.2 & \\
\hline $\mathrm{C} 2 \mathrm{H} 6(\mathrm{~kg} / \mathrm{h})$ & & & 8.26 & 8.26 & 8.26 & 8.26 & 8.26 & 8.26 & 8.26 & \\
\hline Sand (kg/h) & & & 39,883 & & & & & & & \\
\hline Char (kg/h) & & & 1,388 & & & & & & & \\
\hline Wood $(\mathrm{kg} / \mathrm{h})$ & 1,851 & 1,851 & & & & & & & & \\
\hline \multicolumn{11}{|l|}{ Ash $(\mathrm{kg} / \mathrm{h})$} \\
\hline Total $(\mathrm{kg} / \mathrm{h})$ & 3,701 & 2,079 & 43,626 & 2,355 & 2,355 & 2,355 & 2,355 & 2,775 & 2,775 & 2,775 \\
\hline
\end{tabular}


Table B4 - Stream Table for Integrated Gasifier/MCFC Design (SI Units) - Continued

\begin{tabular}{|c|c|c|c|c|c|c|c|c|c|c|}
\hline & & & & & & & & & & \\
\hline & & & & & & & & & & \\
\hline Steam \# & 10 & 11 & 12 & 13 & 14 & 15 & 16 & 17 & 18 & 19 \\
\hline Temp. (K) & 923 & 923 & 316 & 782 & 1,127 & 971 & 841 & 923 & 923 & 679 \\
\hline Pressure $(\mathrm{kPa})$ & 148 & 128 & 128 & 128 & 125 & 121 & 121 & 121 & 119 & 115 \\
\hline & & & & & & & & & & \\
\hline $\mathrm{O} 2(\mathrm{~kg} / \mathrm{h})$ & & & 774 & 774 & 437 & 437 & 1,842 & 2,279 & 939 & 939 \\
\hline N2 $(\mathrm{kg} / \mathrm{h})$ & 2.91 & 2.94 & 2,557 & 2,478 & 2,560 & 2,560 & 6,084 & 8,644 & 8,644 & 8,644 \\
\hline $\mathrm{H} 2(\mathrm{~kg} / \mathrm{h})$ & 164 & 27.6 & & 27.6 & & & & & & \\
\hline $\mathrm{CO}(\mathrm{kg} / \mathrm{h})$ & 142 & 202 & & 202 & & & & & & \\
\hline $\mathrm{CO} 2(\mathrm{~kg} / \mathrm{h})$ & 1,694 & 5,486 & 1.7 & 5,487 & 5,805 & 5,805 & 4.03 & 5,809 & 2,123 & 2,123 \\
\hline $\mathrm{H} 2 \mathrm{O}(\mathrm{kg} / \mathrm{h})$ & 697 & 2,081 & 21.3 & 2,102 & 2,350 & 2,350 & 50.8 & 2,401 & 2,401 & 2,401 \\
\hline $\mathrm{CH} 4(\mathrm{~kg} / \mathrm{h})$ & 73. & .02 & & .02 & & & & & & \\
\hline H2S (kg/h) & 1.61 & 1.58 & & 1.58 & & & & & & \\
\hline SO2 (kg/h) & & & & & 2.97 & 2.97 & & 2.97 & 2.97 & 2.97 \\
\hline NH3 (kg/h) & .03 & & & & & & & & & \\
\hline $\cos (\mathrm{kg} / \mathrm{h})$ & .04 & .07 & & .07 & & & & & & \\
\hline Tar - C10H8 (kg/h) & & & & & & & & & & \\
\hline $\mathrm{C} 2 \mathrm{H} 2(\mathrm{~kg} / \mathrm{h})$ & & & & & & & & & & \\
\hline $\mathrm{C} 2 \mathrm{H} 4$ (kg/h) & & & & & & & & & & \\
\hline $\mathrm{C} 2 \mathrm{H} 6(\mathrm{~kg} / \mathrm{h})$ & & & & & & & & & & \\
\hline Sand $(\mathrm{kg} / \mathrm{h})$ & & & & & & & & & & \\
\hline Char $(\mathrm{kg} / \mathrm{h})$ & & & & & & & & & & \\
\hline Wood $(\mathrm{kg} / \mathrm{h})$ & & & & & & & & & & \\
\hline Ash $(\mathrm{kg} / \mathrm{h})$ & & & & & & & & & & \\
\hline Total $(\mathrm{kg} / \mathrm{h})$ & 2,775 & 7,801 & 3,354 & 11,073 & 11,155 & 11,155 & 7,981 & 19,136 & 14,110 & 14,110 \\
\hline
\end{tabular}




\begin{tabular}{|c|c|c|c|c|c|c|c|c|c|c|}
\hline \multicolumn{11}{|c|}{ Table B4 - Stream Table for Integrated Gasifier/MCFC Design (SI Units) - Continued } \\
\hline Steam \# & 20 & 21 & 22 & 23 & 24 & 25 & 26 & 27 & 28 & 29 \\
\hline Temp. (K) & 629 & 537 & 288 & 288 & 316 & 444 & 288 & 336 & 333 & 422 \\
\hline Pressure $(\mathrm{kPa})$ & 111 & 108 & 101 & 101 & 127 & 793 & 172 & 172 & 3,551 & 3,551 \\
\hline $\mathrm{O} 2(\mathrm{~kg} / \mathrm{h})$ & 939 & 939 & 774 & 1.842 & 1.842 & & & & & \\
\hline N2 $(\mathrm{kg} / \mathrm{h})$ & 8,644 & 8,644 & 2,557 & 6,084 & 6,084 & & & & & \\
\hline $\mathrm{H} 2(\mathrm{~kg} / \mathrm{h})$ & & & & & & & & & & \\
\hline \multicolumn{8}{|l|}{$\mathrm{CO}(\mathrm{kg} / \mathrm{h})$} & & & \\
\hline $\mathrm{CO} 2(\mathrm{~kg} / \mathrm{h})$ & 2,123 & 2,123 & 1.7 & 4.03 & 4.03 & & & & & \\
\hline $\mathrm{H} 2 \mathrm{O}(\mathrm{kg} / \mathrm{h})$ & 2,401 & 2,401 & 21.3 & 50.8 & 50.8 & 420 & 420 & 3,430 & 3,850 & 3,850 \\
\hline \multicolumn{11}{|l|}{$\mathrm{CH} 4(\mathrm{~kg} / \mathrm{h})$} \\
\hline \multicolumn{11}{|l|}{$\mathrm{H} 2 \mathrm{~S}(\mathrm{~kg} / \mathrm{h})$} \\
\hline $\mathrm{SO} 2(\mathrm{~kg} / \mathrm{h})$ & 2.97 & 2.97 & & & & & & & & \\
\hline \multicolumn{11}{|l|}{$\mathrm{NH} 3(\mathrm{~kg} / \mathrm{h})$} \\
\hline \multicolumn{11}{|c|}{$\cos (\mathrm{kg} / \mathrm{h})$} \\
\hline \multicolumn{11}{|c|}{ Tar - C10H8 (kg/h) } \\
\hline \multicolumn{11}{|c|}{$\mathrm{C} 2 \mathrm{H} 2(\mathrm{~kg} / \mathrm{h})$} \\
\hline \multicolumn{11}{|l|}{$\mathrm{C} 2 \mathrm{H} 4$ (kg/h) } \\
\hline \multicolumn{11}{|l|}{$\mathrm{C} 2 \mathrm{H} 6(\mathrm{~kg} / \mathrm{h})$} \\
\hline \multicolumn{11}{|l|}{ Sand $(\mathrm{kg} / \mathrm{h})$} \\
\hline \multicolumn{11}{|l|}{ Char $(\mathrm{kg} / \mathrm{h})$} \\
\hline \multicolumn{11}{|l|}{ Wood $(\mathrm{kg} / \mathrm{h})$} \\
\hline \multicolumn{11}{|l|}{ Ash (kg/h) } \\
\hline Total $(\mathrm{kg} / \mathrm{h})$ & 14.110 & 14.110 & 3.354 & 7.981 & 7.981 & 420 & 420 & 3,430 & 3.850 & 3.850 \\
\hline
\end{tabular}


Table B4 - Stream Table for Integrated Gasifier/MCFC Design (SI Units) - Continued

\begin{tabular}{|c|c|c|c|c|c|c|c|c|c|}
\hline Steam \# & 30 & 31 & 32 & 33 & 34 & 35 & 36 & 37 & 39 \\
\hline Temp. (K) & 517 & 599 & 457 & 457 & 583 & 336 & 317 & 325 & 288 \\
\hline Pressure (kPa) & 3,551 & 3,551 & 793 & 793 & 793 & 21 & 345 & 345 & 172 \\
\hline $\mathrm{O} 2(\mathrm{~kg} / \mathrm{h})$ & & & & & & & & & \\
\hline N2 (kg/h) & & & & & & & & & \\
\hline $\mathrm{H} 2(\mathrm{~kg} / \mathrm{h})$ & & & & & & & & & \\
\hline $\mathrm{CO}(\mathrm{kg} / \mathrm{h})$ & & & & & & & & & \\
\hline CO2 (kg/h) & & & & & & & & & \\
\hline $\mathrm{H} 2 \mathrm{O}(\mathrm{kg} / \mathrm{h})$ & 3,850 & 3,850 & 3,850 & 3,430 & 3,430 & 3,430 & 236,153 & 236,153 & 828 \\
\hline $\mathrm{CH} 4(\mathrm{~kg} / \mathrm{h})$ & & & & & & & & & \\
\hline $\mathrm{H} 2 \mathrm{~S}(\mathrm{~kg} / \mathrm{h})$ & & & & & & & & & \\
\hline SO2 (kg/h) & & & & & & & & & \\
\hline NH3 $(\mathrm{kg} / \mathrm{h})$ & & & & & & & & & \\
\hline $\operatorname{COS}(\mathrm{kg} / \mathrm{h})$ & & & & & & & & & \\
\hline Tar - C10H8 (kg/l & & & & & & & & & \\
\hline $\mathrm{C} 2 \mathrm{H} 2(\mathrm{~kg} / \mathrm{h})$ & & & & & & & & & \\
\hline $\mathrm{C} 2 \mathrm{H} 4(\mathrm{~kg} / \mathrm{h})$ & & & & & & & & & \\
\hline $\mathrm{C} 2 \mathrm{H} 6(\mathrm{~kg} / \mathrm{h})$ & & & & & & & & & \\
\hline Sand $(\mathrm{kg} / \mathrm{h})$ & & & & & & & & & \\
\hline Char $(\mathrm{kg} / \mathrm{h})$ & & & & & & & & & \\
\hline Wood (kg/h) & & & & & & & & & \\
\hline Ash (kg/h) & & & & & & & & & \\
\hline Total $(\mathrm{kg} / \mathrm{h})$ & 3,850 & 3,850 & 3,850 & 3,430 & 3,430 & 3,430 & 236,153 & 236,153 & 828 \\
\hline
\end{tabular}




\begin{tabular}{|l|r|r|r|r|r|r|r|r|r|}
\hline Table B4 - Stream Table for Integrated Gasifier/MCFC Design (SI Units) - Continued & & \\
\hline & & & & & & \\
\hline
\end{tabular}


Table B4 - Stream Table for Integrated Gasifier/MCFC Design (SI Units) - Continued

\begin{tabular}{|c|c|c|c|c|c|c|c|c|c|}
\hline Steam \# & 50 & 51 & 52 & 53 & 54 & 55 & 57 & 58 & 59 \\
\hline Temp. (K) & 357 & 478 & 1,256 & 1,166 & 1,073 & 734 & 288 & 295 & 506 \\
\hline Pressure $(\mathrm{kPa})$ & 177 & 172 & 169 & 165 & 161 & 157 & 101 & 108 & 108 \\
\hline & & & & & & & & & \\
\hline $\mathrm{O} 2(\mathrm{~kg} / \mathrm{h})$ & 1,373 & 1,373 & 428 & 428 & 428 & 428 & 2,313 & 2,313 & 3,680 \\
\hline N2 (kg/h) & 4,535 & 4,535 & 4,535 & 4,535 & 4,535 & 4,535 & 7,638 & 7,638 & 20,817 \\
\hline $\mathrm{H} 2(\mathrm{~kg} / \mathrm{h})$ & & & & & & & & & \\
\hline $\mathrm{CO}(\mathrm{kg} / \mathrm{h})$ & & & & & & & & & \\
\hline CO2 $(\mathrm{kg} / \mathrm{h})$ & 3.01 & 3.01 & 1,336 & 1,336 & 1,336 & 1,336 & 5.08 & 5.08 & 3,465 \\
\hline $\mathrm{H} 2 \mathrm{O}(\mathrm{kg} / \mathrm{h})$ & 37.8 & 37.8 & 189 & 189 & 189 & 189 & 64. & 64. & 2,654 \\
\hline $\mathrm{CH} 4(\mathrm{~kg} / \mathrm{h})$ & & & & & & & & & \\
\hline $\mathrm{H} 2 \mathrm{~S}(\mathrm{~kg} / \mathrm{h})$ & & & & & & & & & \\
\hline SO2 (kg/h) & & & .28 & .28 & .28 & .28 & & & 3.25 \\
\hline NH3 (kg/h) & & & & & & & & & \\
\hline $\operatorname{COS}(\mathrm{kg} / \mathrm{h})$ & & & & & & & & & \\
\hline Tar - C10H8 (kg/l & & & & & & & & & \\
\hline $\mathrm{C} 2 \mathrm{H} 2(\mathrm{~kg} / \mathrm{h})$ & & & & & & & & & \\
\hline $\mathrm{C} 2 \mathrm{H} 4(\mathrm{~kg} / \mathrm{h})$ & & & & & & & & & \\
\hline $\mathrm{C} 2 \mathrm{H} 6(\mathrm{~kg} / \mathrm{h})$ & & & & & & & & & \\
\hline Sand $(\mathrm{kg} / \mathrm{h})$ & & & & & & & & & \\
\hline Char (kg/h) & & & & & & & & & \\
\hline Wood (kg/h) & & & & & & & & & \\
\hline Ash (kg/h) & & & & & & & & & \\
\hline Total $(\mathrm{kg} / \mathrm{h})$ & 5,949 & 5,949 & 6,489 & 6,489 & 6,489 & 6,489 & 10,020 & 10,020 & 30,618 \\
\hline
\end{tabular}




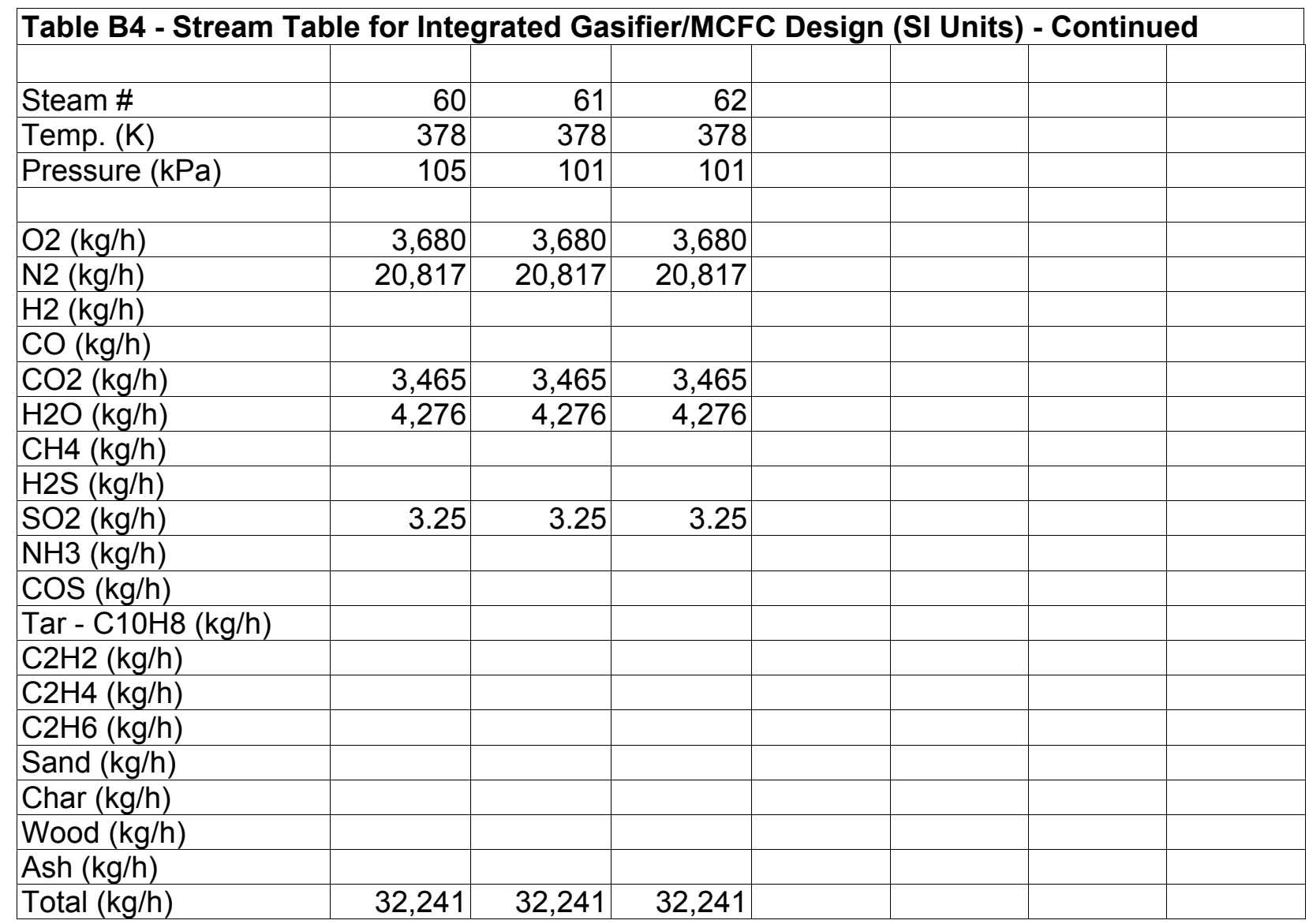




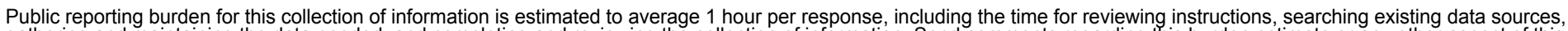

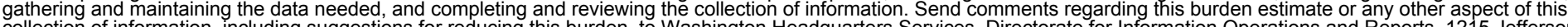

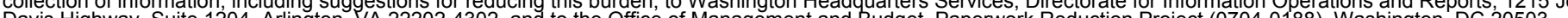
Davis Highway, Suite 1204, Arlington, VA 22202-4302, and to the Office of Management and Budget, Paperwork Reduction Project (0704-0188), Washington, DC 20503.

\begin{tabular}{|l|l|l|l}
\hline 1. AGENCY USE ONLY (Leave blank) & $\begin{array}{c}\text { 2. REPORT DATE } \\
\text { November } 1998\end{array}$ & $\begin{array}{l}\text { 3. REPORT TYPE AND DATES COVERED } \\
\text { Technical Report }\end{array}$ \\
\hline
\end{tabular}

\section{TITLE AND SUBTITLE}

Analysis of Two Biomass Gasification/Fuel Cell Scenarios for Small-Scale Power Generation

5. FUNDING NUMBERS

BP911030

\section{AUTHOR(S)}

W.A. Amos

\section{PERFORMING ORGANIZATION NAME(S) AND ADDRESS(ES)}

National Renewable Energy Laboratory

1617 Cole Boulevard

Golden, CO 80401-3393

\section{SPONSORING/MONITORING AGENCY NAME(S) AND ADDRESS(ES)}

National Renewable Energy Laboratory

1617 Cole Boulevard

Golden, CO 80401-3393

\section{PERFORMING ORGANIZATION} REPORT NUMBER

10. SPONSORING/MONITORING AGENCY REPORT NUMBER

NREL/TP-570-25886

\section{SUPPLEMENTARY NOTES}

\section{2a. DISTRIBUTION/AVAILABILITY STATEMENT}

12b. DISTRIBUTION CODE

National Technical Information Service

U.S. Department of Commerce

5285 Port Royal Road

Springfield, VA 22161

13. ABSTRACT (Maximum 200 words) Two scenarios were examined for small-scale electricity production from biomass using a gasifier/fuel cell system. In one case, a stand-alone BCL/FERC gasifier is used to produce synthesis gas that is reformed and distributed through a pipeline network to individual phosphric acid fuel cells. In the second design, the gasifier is integrated with a molten carbonate fuel cell stack and a steam bottoming cycle. In both cases, the gasifiers are fed the same amount of material, with the integrated system producing $4 \mathrm{MW}$ of electricity, and the stand-alone design generating $2 \mathrm{MW}$ of electricity.

\section{SUBJECT TERMS}

fuel cell, biomass, gasifier, synthesis gas

\section{NUMBER OF PAGES}

77

16. PRICE CODE

\section{SECURITY CLASSIFICATION} OF REPORT

\section{SECURITY CLASSIFICATION} OF THIS PAGE

\section{SECURITY CLASSIFICATION} OF ABSTRACT
20. LIMITATION OF ABSTRACT

Standard Form 298 (Rev. 2-89) Prescribed by ANSI Std. Z39-18
NSN 7540-01-280-5500 